\title{
Prospectiva estratégica aplicada a la hacienda pública: Un ejercicio para la gestión de sus activos y pasivos al año 2030*
}

\section{Strategic foresight applied to the public treasury: An exercise for the management of its assets and liabilities per year}

\begin{abstract}
Renzo A. Jiménez Sotelo**
RESUMEN

Este trabajo muestra una aplicación del planeamiento estratégico prospectivo como herramienta para mejorar la toma de decisiones a futuro dentro del estado. Para ello, se utiliza el método de escenarios y estrategia prospectiva aplicado a un ejercicio de mejora de la gestión del patrimonio financiero de la hacienda pública de una economía pequeña, abierta y parcialmente dolarizada como la peruana. En el ejercicio se diseñaron cinco escenarios futuros posibles a partir de los cuales se construyó un escenario apuesta, tomando como referencia los resultados actuales y las lecciones del pasado, con el fin de responder a lo que podría suceder (riesgos y oportunidades) y a las acciones estratégicas que se deberían implementar para alcanzar los objetivos de dicho escenario. En el documento se reconoce la diferente importancia histórica dada a la prospectiva como herramienta de anticipación
\end{abstract}

\footnotetext{
*Este trabajo también se encuentra depositado en el Munich Personal RePEc Archive (MPRA) desde el 2017. URI: https://mpra.ub.uni-muenchen.de/id/eprint/80862

Este documento está basado en la experiencia de investigación aplicada que el autor lideró sobre planeamiento estratégico prospectivo con el apoyo de E. Olavegoya, J. Sifuentes, L. Cubas, F. Henríquez y J. Gutiérrez, después del entrenamiento provisto por CEPLÁN para el Ministerio de Economía y Finanzas entre fines de 2013 e inicios de 2015 con el invaluable soporte de L. Flores y B. Rosado y cuyos resultados se utilizaron para formular la Estrategia de Gestión Global de Activos y Pasivos 2015-2018. No obstante, todos los análisis, opiniones y conclusiones expresadas, así como cualquier error subsistente, son de exclusiva responsabilidad del autor.
}

** Escuela de Gestión Pública, Universidad del Pacífico (ra.jimenezs@up.edu.pe)

(C) Los autores. Este artículo es publicado por Pensamiento Crítico de la Facultad de Ciencias Económicas, Universidad Nacional Mayor de San Marcos. Este es un artículo de acceso abierto, distribuido bajo los términos de la licencia Creative Commons Atribucion - No Comercia_Compartir Igual 4.0 Internacional. (http:// creativecommons.org/licenses/by-nc-sa/4.0/) que permite el uso no comercial, distribución y reproducción en cualquier medio, siempre que la obra original sea debidamente citada. 
estratégica dentro de los estados de los países desarrollados frente a la que, desafortunadamente, no se le ha dado en la mayoría de países latinoamericanos. Por ello, se espera que documento contribuya a difundir la viabilidad de su aplicación gubernamental de dichos países.

Palabras clave: Tesoro público; deuda pública; planeamiento estratégico; política fiscal. Clasificación JEL: C90, E62, G00, 038.

\section{ABSTRACT}

This paper shows a methodological application of prospective strategic planning as a tool to improve future decision making within the state. To do this, the method of scenarios and prospective strategy applied to an exercise of improving the management of the financial equity of the public treasury of a small, open and partly dollarized economy such as the Peruvian one is used. In the exercise, five possible future scenarios were designed from which an aspirational scenario was constructed, based on current results and lessons from the past, in order to respond to what could happen (risks and opportunities) and the strategic actions that should be implemented to achieve the objectives of such scenario. The document recognizes the different historical importance given to the prospective as a tool of strategic anticipation within the states of developed countries, which unfortunately has not been given in most Latin American countries. Therefore, it is hoped that document will contribute to spread the viability of its application in government entities of these countries.

Keywords: Public treasury; public debt; strategic planning; fiscal policy.

Nota del editor: Esta investigación fue expuesta en el Congreso Anual 2017 de la Asociación Peruana de Economía (APE) y pre-publicada como documento de trabajo en el repositorio MPRA de la red de investigadores RePEc

\section{Introducción}

¿A qué país no le gustaría anticipar su futuro y, de considerarlo pertinente, cambiarlo? ¿Cómo habrían modificado su historia los incas y demás pueblos americanos aborígenes que inicialmente trataron a los europeos como invitados, o incluso aliados, si hubieran anticipado las consecuencias disruptivas que su llegada al continente iba a tener sobre su futuro? Tal vez mucho o quizás poco, pero sí habrían decidir si querían modificar su futuro. La prospectiva es una herramienta que permite explorar y visionar futuros alternativos para, luego de escoger el más deseado, irlo construyendo estratégicamente a partir de la realidad presente. Por ello, las empresas que más han crecido sostenidamente son aquellas que mayor visión de futuro han tenido, planificando cómo alcanzar lo que más les conviene y cómo 
evitar o mitigar lo que más les perjudica, dejando lo menos posible al azar. Así, las empresas exitosas no han sido las que mayor oferta produjeron esperando la creación de su propia demanda, sino las que crearon una mejor oferta anticipando su futura demanda. Algo análogo también ha sucedido con los países que más se han desarrollado, ya que no puede haber desarrollo sostenible con improvisación sistemática.

Según la definición propuesta por Ackoff (1973), planificación es "concebir un futuro deseado así como los medios necesarios para alcanzarlo" (citado en Godet y Durance 2007: 8). Desafortunadamente, suele existir una falta de visión sobre el valor estratégico que tiene la planificación en el estado. Por lo general, las tareas de identificación, diseño, ejecución y evaluación de políticas públicas se desarrollan sin un marco de planeamiento estratégico que permita ordenar y orientar las acciones hacia un desarrollo integral de un país, una región, un municipio o una institución (Medina y Oregón 2006, p. 61). Sin objetivos estratégicos ni metas de largo plazo, la asignación de recursos se vuelve miope y vulnerable al capricho de los políticos de turno y el de los intereses particulares de los grupos de interés que los rodean, haciendo que ineficientemente no se aprovechen bien los recursos públicos o se dupliquen los esfuerzos por fallas de coordinación entre los diversos niveles operativos del estado. Esto es más crítico en países donde, además, no existe aprobación de un presupuesto multianual que obligue a alargar los horizontes de planificación pública más allá de los 12 meses de los tradicionales presupuestos anuales.

Según Nardelli (2006, p. 24), uno de los primeros esfuerzos latinoamericanos para explorar opciones futuras de desarrollo a largo plazo de manera más o menos sistemática se produjo en el Séptimo Congreso de la Sociedad Interamericana de Planificación que se celebró en Lima en 1969 y se centró en la América del año 2000. Como producto de dicho evento no sólo se publicaron cinco volúmenes ${ }^{1}$, sino que el gobierno peruano por primera vez elaboró un plan de largo plazo: diez años. El sistema nacional de planificación en el Perú había sido creado en 1962

\footnotetext{
${ }^{1}$ Uno sobre la situación social en Latinoamérica en el año 2000, editado por Horacio Godoy; un segundo sobre las políticas nacionales e internacionales en Latinoamérica en el año 2000, editado por Kalman Silvert; un tercero sobre integración económica y desarrollo, editado por Claudio Véliz; un cuarto sobre la nueva cultura latinoamericana, editado por Harvey Perloff; y un quinto sobre demografía y planificación en Latinoamérica, editado por José Donaire (Nardelli 2006).
} 
con el Instituto Nacional de Planificación como organismo técnico central responsable (GP 1962), sistema que fue mejorado con la promulgación de su ley orgánica (GP 1981). Sin embargo, tras el golpe de estado de $1992^{2}$, dicha institución fue disuelta y desactivada ese mismo año (GP 1992) y su personal fue transferido o puesto a disposición como excedente, en tanto que sus funciones fueron asumidas de modo genérico por el Ministerio de Economía y Finanzas (MEF), en donde no se creó ningún área especializada a cargo.

Según Medina y Oregón (2006, p. 114-115), hubo una falta de visión estratégica sobre la planificación en el estado en casi toda América Latina que llevó a que, después del fin de la guerra fría, la mayoría de las funciones de planeamiento pasaran a los ministerios de economía, los ministerios de finanzas o las secretarías de presidencia, o se consideraran innecesarias y fueran suprimidas. Todo esto a pesar de que desde finales de los años 80 los principales países industrializados habían venido haciendo exactamente lo contrario. En los países desarrollados la valoración de la investigación acerca del futuro se había plasmado principalmente a través de la exploración estratégica de los sectores tecnológicos que le convendría desarrollar a cada país, de su aplicación a los procesos de reconversión de su estructura productiva y de la promoción de nuevos sectores económicos. Por tanto, resultó un completo embuste el haber hecho creer que en las economías de mercado no existía pensamiento ni planificación a largo plazo, ya que las principales metodologías de estudios del futuro fueron desarrolladas y puestas en marcha por las propias corporaciones multinacionales, las cuales continúan invirtiendo enormes recursos financieros y gran capital humano en procesos de investigación y desarrollo, evaluación tecnológica, análisis de entorno y riesgo país, evaluaciones de impacto ambiental, etc.

Un ejemplo concreto del uso del enfoque de la investigación de escenarios futuros entre los países más desarrollados es el Programa

\footnotetext{
${ }^{2}$ El golpe del 3 de octubre de 1968 había dado paso a una dictadura que terminó implementando sorpresivamente una serie de reformas de radical carácter izquierdista (Quiroz 2013: 402-408), con un gran intervencionismo del Estado en la economía, mientras que el golpe del 5 de abril de 1992 dio paso a una dictadura para consolidar la implementación de una serie de contrarreformas de radical carácter derechista, las cuales tampoco habían sido esperadas (Quiroz 2013: 446-457), con el objetivo de reducir al Estado a su más mínima expresión. Según las estadísticas del Banco Central de Reserva del Perú, los ingresos corrientes de las empresas no financieras estatales entre 1970 y 1980 pasaron de $4.1 \%$ a $29.8 \%$ del producto interno bruto y entre 1990 y 2000 pasaron de $16.1 \%$ a $7.3 \%$.
} 
International de Futuros de la Organización para la Cooperación y el Desarrollo Económico (OCDE), el cual desde el 1990 tuvo como objetivos: (i) mejorar la capacidad de diálogo entre los países miembros, (ii) compartir información calificada, (iii) generar apoyo para el establecimiento de agendas de políticas públicas mediante la elaboración de mapas estratégicos, (iv) vigilar problemas a largo plazo, identificar las fuerzas clave y tendencias del entorno, y (v) dar alertas tempranas y contribuir a la apreciación analítica sobre asuntos emergentes. Según Medina y Oregón (2006, p. 100), en el encuentro con investigadores de los Estados Unidos, organizado en 2004 por el Instituto de Prospectiva Tecnológica de la Unión Europea creado en 1994, se llegó a la conclusión de que los países y las organizaciones tienden cada vez más al desarrollo de procesos y sistemas de prospectiva en lugar de realizar prácticas puntuales y ocasionales, lo que significa que se prefiere la construcción permanente de futuros en lugar de la exploración casual o asistemática de los futuros alternativos de un país, una región, un sector industrial o un área de ciencia, tecnología e innovación.

No obstante, apenas el sistema nacional de planificación del Perú fue desactivado, y se empezó a implementar el proceso de apertura económica del país a inicios de los años 90, las grandes empresas financieras locales, entusiastas protagonistas de las reformas implementadas, fueron las primeras en contratar los servicios de consultoría en planeamiento y estrategia a grandes firmas internacionales como Arthur D. Little, Andersen Consulting (hoy Accenture), Boston Consulting Group, McKensey \& Company, entre otros. Y según Medina y Oregón (2006: 267), en realidad dichas firmas, junto a otras como Booz Allen Hamilton Inc., Monitor Company y Stanford Research Institute, ya habían empezado a incursionar con agresividad en toda América Latina, tanto en el campo del desarrollo institucional como en el de la elaboración de planes estratégicos urbano-regionales y empresariales. En consecuencia, no pareciera casualidad que durante más de dos décadas el estado peruano actuara sin siquiera un sistema de previsión de las consecuencias a largo plazo de sus propias acciones y de las de su entorno.

Según Balbi (2014, p. 14-21), la principal demanda estratégica de todo líder, público o privado, está en la imperiosa necesidad de lograr una eficiente gestión estratégica de riesgos y oportunidades, para lo cual se requiere el 
desarrollo de habilidades de anticipación estratégica que permitan no sólo detectar y aprovechar lo que podrían ocurrir en el futuro, sino también generar nuevas oportunidades. Una anticipación estratégica continua para la gestión se logra, primero, a través de la prospectiva estratégica, que es el soporte metodológico para explorar el futuro e intentar deducir, descubrir o imaginar qué va a pasar y cuáles podrían ser sus impactos sobre nuestros objetivos y metas, $\mathrm{y}$, segundo, a través de la inteligencia estratégica, que es el producto de la aplicación de dicha metodología y que en el mundo corporativo se suele denominar inteligencia de negocios, inteligencia competitiva, inteligencia tecnológica, etc. Los productos más importantes de la inteligencia estratégica basada en prospectiva son mapas de riesgos y oportunidades a futuro, sistemas de alertas tempranas, puntos críticos de tolerancia, escenarios exploratorios y críticos, escenario óptimo de matrices referenciales de calidad, entre otros.

La aplicación mostrada en este documento usa como insumo el trabajo de investigación prospectiva efectuado entre 2013 y 2015 con expertos y especialistas multidisciplinarios de las entidades públicas adscritas al Sector Economía y Finanzas ${ }^{3}$ en atención al nuevo proceso de planeamiento estratégico aprobado por CEPLÁN (2014), casi 6 años después de haber sido creado por segunda vez (ver CRP 2005 y GP 2008), y cuyos resultados sirvieron para aprobar la estrategia publicada por el MEF (2015a). Según Balbi (2015), experto contratado para participar en la revisión y complemento de la directiva involucrada, esta incorporación del análisis prospectivo como parte del proceso de planeamiento estratégico de la administración pública en el Perú sería uno de los casos más avanzados en toda la región en los últimos 40 años, como un esfuerzo por profundizar una cultura de visiones de largo plazo y de utilización de la prospectiva para la anticipación estratégica. El ejercicio también muestra que los cambios que se habían estado implementando desde 2011 para lograr una gestión global de activos y pasivos financieros en el estado,

\footnotetext{
${ }^{3}$ Además del Ministerio de Economía y Finanzas, pertenecen al Sector Economía y Finanzas, como organismos públicos adscritos, la Superintendencia Nacional de Aduanas y de Administración Tributaria (SUNAT), la Superintendencia del Mercado de Valores (SMV), la Agencia de Promoción de la Inversión Privada (PROINVERSIÓN), el Organismo Supervisor de las Contrataciones del Estado (OSCE) y la Oficina de Normalización Previsional (ONP), y, como empresas públicas vinculadas, el Fondo Nacional de Financiamiento de la Actividad Empresarial del Estado (FONAFE) y al Banco de la Nación (BN). No participaron la Superintendencia de Banca, Seguros y AFP (SBS) ni el Banco Central de Reserva (BCRP).
} 
cuyas principales líneas de acción habían sido publicadas resumidamente en MEF (2013) y con mayor detalle en MEF (2014a), eran consistentes con esta visión de futuro.

Luego de esta primera sección introductoria, en la segunda sección se hace un sintético resumen del marco teórico de la prospectiva. En la tercera sección se desarrolla muy resumidamente el ejercicio de aplicación en cada una de sus etapas y en la cuarta sección se muestran las conclusiones. Se espera que el documento contribuya a difundir la viabilidad de la aplicación pragmática de la prospectiva estratégica dentro de las entidades gubernamentales: un ejercicio de anticipación de futuro que requerirá ser efectuado de manera sistemática y permanente.

\section{Marco teórico}

Según Miklos y Tello (2007, p. 15), existen cinco grandes enfoques para estudiar el futuro: la proyección, la predicción, la previsión, el pronóstico y la prospectiva. Una proyección toma datos del pasado y presente y, a través de métodos matemáticos, estadísticos o cualitativos, los lleva al futuro, partiendo de la continuidad de las tendencias. Una predicción se basa en una visión determinista, presentando enunciados irrebatibles sobre lo que necesariamente va a suceder. Una previsión toma acciones en el presente para resolver anticipadamente los problemas que puedan surgir en el futuro inmediato. Un pronóstico representa un juicio razonado sobre un asunto importante que se tomará como base de algún programa de acción. En cambio, la prospectiva concentra la atención sobre el porvenir, imaginándolo a partir del futuro mismo, construyéndolo, de entre todos los futuros posibles y deseables, a partir de la realidad.

Existen diversos enfoques y corrientes donde la prospectiva juega un rol diferente, pero en todos los casos la prospectiva se dirige al futuro para después retomar la riqueza del presente y el pasado. De esta manera, la prospectiva se preocupa más por brindar alternativas futuras que se pueden diseñar o construir, en lugar de responder a la pregunta qué sucederá irremediablemente. Es decir, su actitud frente al futuro es activa y creativa, en lugar de pasiva o adaptativa. Por tanto, la prospectiva contempla el futuro cercano como una etapa para la construcción de un futuro lejano más conveniente, trabajando así las acciones del presente en función del futuro deseado probable y posible (Miklos y Tello 2007, p. 
28). Según Balbi (2014, p. 24), la prospectiva, en todas sus variantes, tiene un eje metodológico común que se constituye en la columna vertebral del proceso respectivo y alimenta la mayoría de los diseños metodológicos elaborados para llevar adelante investigaciones prospectivas y es el que indica el orden en el que se sugiere debieran adquirirse los conocimientos (Gráfico 1). Así, para dicho autor, la prospectiva en sentido amplio equivale a inteligencia (pasos 1 al 5), mientras que, siguiendo a la escuela francesa, la prospectiva estratégica equivale al proceso continuo de inteligencia y de diseño estratégico y planeamiento (pasos 1 al 7).

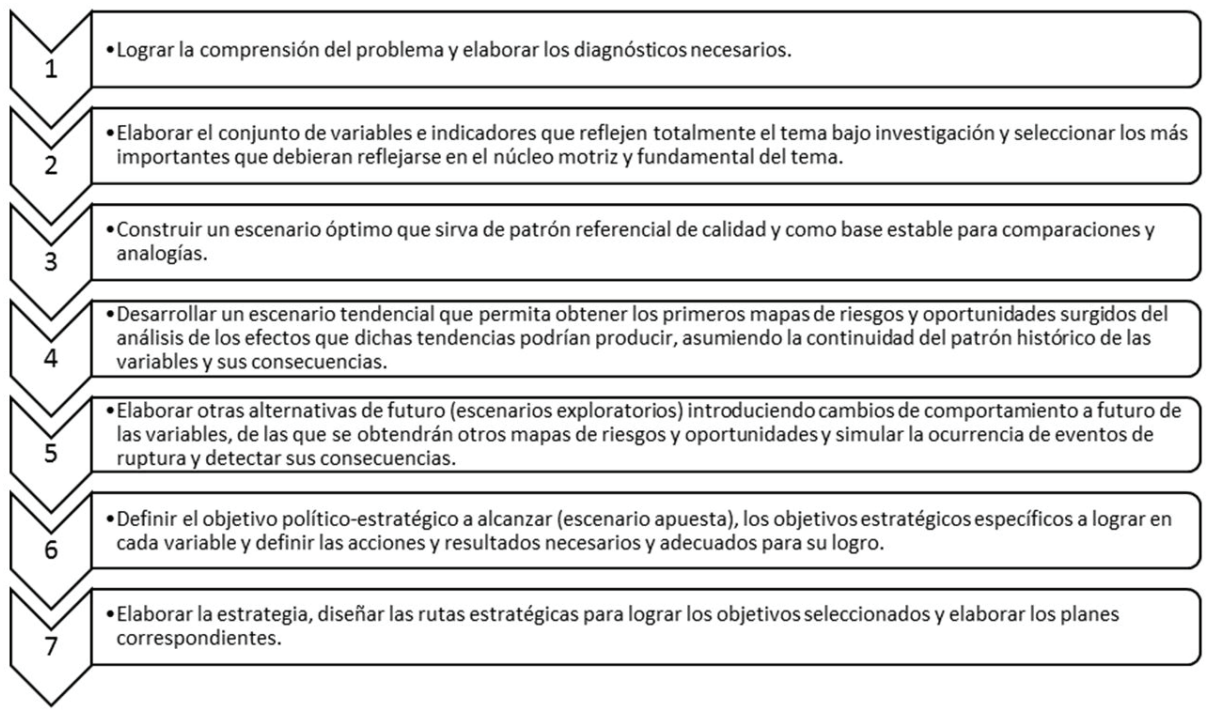

Gráfico1. Eje metodológico general de la prospectiva Fuente: MEF (2015a). Elaboración: Propia

Según Godet y Durance (2007, p. 6-13), la anticipación no tiene mayor sentido si no sirve para esclarecer la acción, de modo que la prospectiva y la estrategia son generalmente indisociables y por ello la expresión de prospectiva estratégica debe ser reservada a los ejercicios de prospectiva que tengan ambiciones y persigan fines estratégicos para el actor que las emprende. Así, la prospectiva sola se centra en el ¿qué puede ocurrir?, pero se convierte en prospectiva estratégica cuando alguien se interroga sobre el ¿qué puede hacer?, el ¿qué va a hacer? y el ¿cómo lo va a hacer? Para ello habrá que resolver múltiples interrogantes en cuanto a objetivos, 
contenidos, metas, recursos y necesidades de la investigación, de modo que se tendrá que recurrir a diferentes técnicas e instrumentos (Cuadro 1) en función al carácter que tendrá la investigación, a las expectativas que orientarán su desarrollo, al tipo de información con el que se contará, a los niveles de decisión en los que se difundirán los resultados, etc. (Miklos y Tello 2014, p. 99-110).

\section{Cuadro 1.}

Técnicas e instrumentos utilizados en prospectiva

\begin{tabular}{|c|c|c|c|}
\hline Técnicas cualitativas & $\begin{array}{l}\text { Técnicas } \\
\text { cuantitativas }\end{array}$ & Técnica mixtas & Instrumentos \\
\hline $\begin{array}{l}\text { Analogías } \\
\text { Árbol de pertinencia } \\
\text { Compass } \\
\text { Conferencia de búsqueda } \\
\text { Imágenes alternativas } \\
\text { Intuiciones sistemáticas } \\
\text { KJ } \\
\text { Mapeo contextual }\end{array}$ & $\begin{array}{l}\text { Estadística bayesiana } \\
\text { Montecarlo } \\
\text { Econometría }\end{array}$ & $\begin{array}{l}\text { Pronóstico } \\
\text { tecnológico } \\
\text { Juegos de simulación } \\
\text { Matriz de decisión }\end{array}$ & $\begin{array}{l}\text { Cuestionario } \\
\text { Diferencial } \\
\text { semántico } \\
\text { Escala de Guttman } \\
\text { Escala de Likert } \\
\text { Escala de Thurstone } \\
\text { Conferencia } \\
\text { Mesa redonda con } \\
\text { interrogador } \\
\text { Entrevista } \\
\text { Poster } \\
\text { Promoción de ideas }\end{array}$ \\
\hline
\end{tabular}

Fuente: Miklos y Tello (2007). Elaboración: Propia

Según el método de escenario y estrategia prospectiva (Balbi 2014, p. 44-46), el proceso prospectivo propiamente dicho puede subdividirse en dos grandes conjuntos de tareas participativas: (a) las del análisis y comprensión del tema de investigación y (b) las de la construcción y evaluación de escenarios y eventos de ruptura. El primer conjunto de tareas busca que el equipo a cargo del estudio efectúe un análisis de la realidad del tema de investigación, de su entorno y problemática a abordar, identificando los componentes que lo integran y los factores que influyen en ellos, de modo que se reconozcan las variables e indicadores endógenos y exógenos que representan el tema de análisis y se pueda seleccionar aquellas de valor estratégico y hacer un diagnóstico de su evolución histórica y estado actual. El segundo conjunto de tareas busca que se analice el comportamiento a futuro de cada uno de las variables e indicadores estratégicos seleccionados y se elaboren y evalúen una serie de escenarios en términos de riesgos y oportunidades que a futuro cada uno de ellos pueda presentar. Además, se selecciona posibles eventos de ruptura a futuro, entre los que puedan afectar significativamente una o más variables en su comportamiento a futuro, y se analizan y evalúan los 
impactos y consecuencias que estos podrían generar, en caso ocurran, en los nuevos escenarios que se generen.

El proceso estratégico, apoyado en la información sensible identificada en el proceso prospectivo, busca fijar un escenario apuesta a ser alcanzado en un plazo de tiempo determinado. La selección de este escenario consolida la visión de la organización involucrada en el estudio para poder comenzar a instrumentar la manera cómo se podrá arribar al final de este proceso, es decir, cuál será el camino para lograrlo. Para ello, una vez seleccionado el escenario apuesta, se construyen los objetivos estratégicos a alcanzar, se establecen los indicadores y metas asociadas a dichos objetivos y se determinan las acciones estratégicas necesarias para alcanzarlos. Luego se elaboran diferentes rutas alternativas, teniendo en cuenta el camino crítico entre ellas, se comparan y evalúan y se define la ruta estratégica contrastándola con los mapas de riesgos y oportunidades. Con todo lo anterior ya definido, se redacta al final el plan estratégico (Balbi 2014, p. 116-119).

\section{Un ejercicio prospectivo de gestión de activos y pasivos de la hacienda pública}

Luego de evaluar y seleccionar las áreas, tendencias, variables e indicadores estratégicos más relevantes para la gestión del patrimonio financiero de la Hacienda Pública peruana, y que se reflejan en su calificación de riesgo soberano, se definieron cinco escenarios con un horizonte al año 2030: i) un escenario óptimo, que sirviera como patrón referencial de calidad, y como base fija para comparaciones y analogías; ii) un escenario base, el escenario tendencial de cada variable estratégica, donde no se tomara ninguna acción adicional a lo que se ha venido realizando en los últimos años, iii) un escenario exploratorio positivo, donde el Perú llegara a formar parte de la OCDE; iv) un escenario exploratorio negativo, donde los precios de las materias primas cayeran en un 50\%; y v) un escenario exploratorio de estrés, en donde la tasa de referencia en los EEUU subiera al 5\%. A continuación, se verá el ejercicio, resumido paso a paso. 


\section{A. Descripción de la temática estudiada}

En este paso se requiere comprender y delimitar el sistema temático bajo estudio, de la manera más libre y amplia posible, con el apoyo de todos los expertos y especialistas multidisciplinarios relevantes, pero libres de cualquier conflicto de intereses y sin dejarse condicionar por el prejuicio inercial de lo que se haya venido haciendo, mejor o peor, desde el pasado, un nivel de desprendimiento muy complejo de lograr. La construcción del árbol de pertinencias permitirá determinar una visión preponderantemente endógena del problema, con sus situaciones críticas, para luego completar la vinculación entre estas áreas temáticas y lo que podría ocurrir en su entorno a futuro.

En el ejercicio, después de un muy amplio y prolongado debate, en reuniones sostenidas a lo largo de varias semanas, se identificó el conjunto de componentes y subcomponentes temáticos más importante del modelo conceptual involucrado (Gráfico 2), cuyas definiciones, para asegurar consistencia y evitar posteriores divergencias de interpretación, se delimitaron claramente, según se detalla en el Anexo 1.

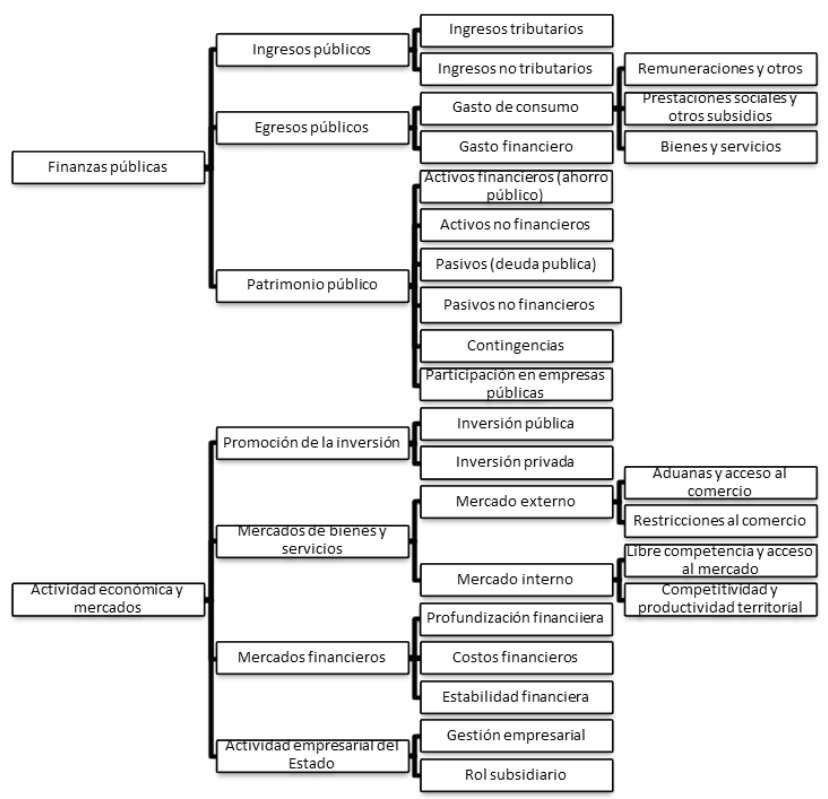

Gráfico 2. Árbol de pertinencias

Fuente: MEF (2015a). Elaboración: Propia 


\section{B. Evaluación de principales tendencias}

Como paso siguiente, los expertos y especialistas relevantes deben analizar las principales tendencias existentes a nivel mundial. Las tendencias identificadas se seleccionan, de entre todas las demás, en función a si tienen, o no, un impacto de gran repercusión, directa o indirecta, sobre el estado actual del desarrollo y competitividad de los componentes temáticos identificados en el árbol de pertinencias. Para ello, se verifica qué componentes y subcomponentes del árbol de pertinencia son afectados y cómo.

En este ejercicio, por su significativo impacto en diferentes temas, las tendencias más relevantes para el modelo conceptual involucrado fueron las detalladas en el Cuadro 2.

\section{Cuadro 2.}

Identificación de tendencias

\begin{tabular}{|l|l|}
\hline № & Tendencias \\
\hline 1 & Expansión económica de China. \\
\hline 2 & Volatilidad del precio de las materias primas. \\
\hline 3 & Globalización y creciente libre movilidad de capitales. \\
\hline 4 & Mayor influencia de los cambios en las políticas monetarias de los países emisores de divisas. \\
\hline 5 & Consolidación de diversos bloques económicos y comerciales. \\
\hline 6 & Incremento de los riesgos por efecto de desastres naturales. \\
\hline 7 & Creciente importancia de la inversión en innovación, ciencia y tecnología. \\
\hline
\end{tabular}

Fuente: MEF (2015a). Elaboración: Propia

\section{Análisis causal de situaciones críticas}

En este paso se analiza el origen de las situaciones críticas existentes en el campo de estudio que es objeto de investigación, es decir, de las situaciones con consecuencias negativas o riesgos particulares que se desean o requieren impedir, reparar, corregir o mejorar. Para ello, se busca llegar a las raíces de las causas de los problemas (con sucesivos "por qué" se generará cada causa hallada), lo que permitirá reconocer los blancos estratégicos sobre los cuales se deberá actuar. Si no existieran situaciones críticas, esta paso se puede obviar (Balbi 2010, p. 31 y 33). 
Considerando lo ya logrado entre 2011 y 2014, en el ejercicio de referencia no se justificó hacer esta evaluación. Anteriormente se había hecho un análisis de investigación causal cuyos blancos estratégicos relevantes se habían aprobado en MEF (2011). Además, según MEF (2013) y MEF (2014a), para corroborar la legitimidad e imparcialidad del diagnóstico hecho con la identificación de situaciones críticas en la gestión patrimonial de la Hacienda Pública, se revisaron los principales estándares y mejores prácticas internacionales, se valoraron las opiniones de expertos y de agencias calificadoras de riesgo contratadas y no contratadas, se hicieron investigaciones internas de comparación con otros países de la región con similar riesgo soberano y se hicieron viajes de investigación a países con mayor desarrollo financiero con apoyo del FMI.

Entrelasprincipalessituacionescríticas relacionadasconlaineficiente gestión de activos y pasivos se encontraban la elevada dolarización financiera, la alta proporción de deuda externa, el bajo desarrollo del mercado de deuda soberana y el poco desarrollado sistema financiero. Y entre sus raíces se hallaban la falta de un sólido marco conceptual para integrar los requerimientos de la gestión de la deuda pública con los de la gestión de la tesorería pública independientemente de su afectación presupuestaria y para privilegiar la evaluación desde un punto de vista económico o social respecto del punto de vista financiero o privado. Esto último es clave porque el estado no es un agente cualquiera, sino que tiene un rol social y sus objetivos son más complejos, cuya actuación tiene externalidadespositivasquedebenincentivarsey externalidadesnegativas que deben mitigarse. Por ejemplo, para desarrollar el mercado de valores de deuda soberana local, el estado debe mantener una mínima frecuencia de subasta de varios puntos de referencia de la curva de rendimientos soberana, a pesar de que en el corto plazo pudiera parecer menos oneroso concentrarse en un solo punto con el cual no se construye ni se mantiene refrescada toda la curva a largo plazo, ni para sus inversionistas locales que buscan una mínima liquidez ni para construir curvas de rendimiento corporativas que puedan ser usadas por las empresas para emitir deuda en el mercado de capitales local en condiciones competitivas frente al ofrecido como deuda externa. En el primer caso, entre las raíces también se hallaba un instrumental de análisis contable y estadístico desfasado de los estándares internacionales. 


\section{Identificación de variables involucradas}

En este paso el método requiere identificar y definir bien las variables más representativas para diagnosticar la situación actual y comprender su evolución histórica y de entorno. Una variable es una cualidad o característica concreta que sea representativa del tema o de la tendencia seleccionada, identificable y distinta de otras, susceptible de cambio y medición. Cada uno de los temas del árbol de pertinencias se convierten en una o más variables que los representen (variables endógenas) y cada tendencia corresponde al comportamiento futuro de una variable relevante (variables exógenas).

\section{Cuadro 3.}

Variables identificadas endógenas

\begin{tabular}{|c|l|l|}
\hline No & Variable & Definición \\
\hline 1 & $\begin{array}{l}\text { Producto interno } \\
\text { bruto }\end{array}$ & $\begin{array}{l}\text { Valor de la producción de bienes y servicios finales generada dentro de } \\
\text { un país durante un periodo determinado. }\end{array}$ \\
\hline 2 & Institucionalidad & $\begin{array}{l}\text { Comprendida como un atributo esencial dentro de un estado de derecho: } \\
\text { mientras más eficientes sean las normas y leyes que se aplican en las } \\
\text { interacciones entre personas, empresas y Estado para generar riqueza, } \\
\text { se tendrá una institucionalidad más avanzada. }\end{array}$ \\
\hline 3 & $\begin{array}{l}\text { Desarrollo } \\
\text { de mercados } \\
\text { financieros }\end{array}$ & $\begin{array}{l}\text { Importancia relativa de los mercados financieros respecto del que } \\
\text { tienen en los países más desarrollados en un entorno multidimensional: } \\
\text { mercado de bonos, operaciones de reportes, derivados, depósitos y } \\
\text { créditos, aseguramiento, cobertura previsional, así como inversión y } \\
\text { financiamiento a través del mercado de valores. }\end{array}$ \\
\hline 4 & $\begin{array}{l}\text { Dolarización } \\
\text { financiera }\end{array}$ & $\begin{array}{l}\text { Es el reemplazo parcial por parte de los agentes económicos de la } \\
\text { moneda local por una moneda extranjera en sus funciones dinerarias } \\
\text { básicas dentro del sistema financiero nacional: i) reserva de valor, ii) } \\
\text { medio de pago y iii) unidad de cuenta. }\end{array}$ \\
\hline 5 & $\begin{array}{l}\text { Estabilidad } \\
\text { financiera }\end{array}$ & $\begin{array}{l}\text { Situación en la que los mercados financieros y las autoridades fiscales, } \\
\text { monetarias, reguladoras y supervisoras facilitan la asignación } \\
\text { eficiente del capital y aseguran el buen funcionamiento de la cadena de } \\
\text { pagos, evalúan y gestionan mejor los riesgos tanto individuales como } \\
\text { sistémicos, resisten a las perturbaciones y disipan los desequilibrios } \\
\text { financieros que surgen como consecuencia de hechos o fenómenos } \\
\text { adversos no anticipados. }\end{array}$ \\
\hline Deuda pública & $\begin{array}{l}\text { Pasivos financieros reconocidos por el gobierno frente al resto de la } \\
\text { economía y el mundo. }\end{array}$ \\
\hline
\end{tabular}




\begin{tabular}{|l|l|l|}
\hline No & Variable & Definición \\
\hline 7 & $\begin{array}{l}\text { Activos no } \\
\text { financieros }\end{array}$ & $\begin{array}{l}\text { Activos que proporcionan beneficios, ya sea por su uso en la producción } \\
\text { de bienes o servicios o porque pueden proporcionar de rentas de } \\
\text { propiedad, distintos de los activos financieros. Los activos no financieros } \\
\text { pueden crearse como resultado de procesos de producción, tener un } \\
\text { origen natural o ser creación de la sociedad. En el caso de los activos } \\
\text { producidos, éstos pueden ser propiedades, plantas y equipos, existencias } \\
\text { u objetos de valor. }\end{array}$ \\
\hline 8 & Ahorro público & $\begin{array}{l}\text { Fondo, caudal y demás activos financieros que se guardan como } \\
\text { previsión del gobierno para necesidades futuras. }\end{array}$ \\
\hline 10 & $\begin{array}{l}\text { Gasto financiero } \\
\text { consumo }\end{array}$ & $\begin{array}{l}\text { Gastos directamente derivados de la gestión financiera, como los que } \\
\text { se derivan de la compra y venta de valores, los pagos de intereses de } \\
\text { créditos recibidos, los pagos de cupones por los valores emitidos, los } \\
\text { pagos de comisiones, etc. }\end{array}$ \\
\hline 11 & $\begin{array}{l}\text { Ingreso público } \\
\text { Gastos que corresponden a egresos de naturaleza periódica destinados } \\
\text { a la adquisición y contratación de bienes y servicios que no constituyen } \\
\text { activos, incluidas las transferencias de recursos sin contraprestación a } \\
\text { otras entidades. }\end{array}$ \\
\hline $\begin{array}{l}\text { Ingresos públicos que provienen de: a) los impuestos, que es el pago } \\
\text { que hacen los contribuyentes por mandato de la ley en las condiciones } \\
\text { que ésta determina, sin que medie una contraprestación directa } \\
\text { yb) los ingresos no tributarios, que provienen del cobro de tasas, } \\
\text { contribuciones, multas, rentas y la venta de bienes y servicios. }\end{array}$ \\
\hline
\end{tabular}

Fuente: MEF (2015a). Elaboración: Propia

En el ejercicio seleccionado, también previo prolongado y amplio debate a lo largo de varias semanas, se identificó el listado de todas las variables endógenas (Cuadro 3) y exógenas (Cuadro 4) que estaban involucradas. Además, como no todas las variables eran susceptibles de ser medidas directamente, para convertirse automáticamente en indicadores, resultó necesario seleccionar o construir los indicadores que permitieran su medición indirecta. Para ello, se debió contar con la definición de cada indicador, la variable a la que estaba asociado, la fórmula de cada indicador y la fuente de donde se podía obtener todos los datos necesarios para que cualquiera pueda construir cada uno de los indicadores y calcularlos (ver Anexo 2). 


\section{Cuadro 4.}

Variables identificadas exógenas

\begin{tabular}{|c|l|l|}
\hline No & Variable & Definición \\
\hline 12 & $\begin{array}{l}\text { Desempeño } \\
\text { económico de } \\
\text { China }\end{array}$ & $\begin{array}{l}\text { Resultados obtenidos por la economía de la República Popular China } \\
\text { y que pueden ser medidos a través de los principales indicadores } \\
\text { macroeconómicos. }\end{array}$ \\
\hline 13 & $\begin{array}{l}\text { Inversión } \\
\text { en ciencia y } \\
\text { tecnología }\end{array}$ & $\begin{array}{l}\text { Creciente importancia de la inversión en innovación, ciencia y tecnología } \\
\text { en el incremento de la productividad laboral. }\end{array}$ \\
\hline 15 & $\begin{array}{l}\text { Mercado de } \\
\text { materias primas }\end{array}$ & $\begin{array}{l}\text { Mercados internacionales en los que se negocian productos no } \\
\text { manufacturados y genéricos con bajo o ningún nivel de diferenciación. }\end{array}$ \\
\hline 16 & $\begin{array}{l}\text { Política } \\
\text { monetaria de los } \\
\text { EEUU }\end{array}$ & $\begin{array}{l}\text { Variación de la cantidad de dinero invertido en un país por individuos o } \\
\text { empresas extranjeras, donde un balance acumulado positivo implica que } \\
\text { la cantidad de inversiones realizadas en un país por extranjeros supera } \\
\text { la cantidad de inversiones realizadas por nacionales en otros países y } \\
\text { viceversa. }\end{array}$ \\
\hline
\end{tabular}

Fuente: MEF (2015a). Elaboración: Propia

\section{E. Análisis y calificación de variables por influencia mutua}

¿Cómo calificar la influencia de las variables? Para ello, en este paso se debe categorizar el grado de influencia mutua que hay entre todas las variables identificadas, tomadas de dos en dos. Así, con mucho tiempo de dedicación, paciencia y buen juicio, todos los expertos y especialistas deben valorar y calificar colegiadamente y con el mismo criterio a todas las variables en una matriz de análisis estructural de acuerdo a los grados de motricidad y de dependencia de cada una respecto de las otras. Por grado de motricidad se entiende a la influencia que una variable pueda desencadenar sobre otras variables, mientras que por grado de dependencia se entiende a la influencia que una variable puede recibir del desempeño de otras variables. La calificación del grado de influencia varía desde 0 , que significa que la influencia es nula, hasta 4 , que corresponde al grado de influencia de muy fuerte (Cuadro 5).

Cuadro 5.

Calificación de variables por influencia

\begin{tabular}{|c|c|}
\hline Calificación & Grado de influencia \\
\hline 0 & Nula \\
\hline 1 & Débil \\
\hline 2 & Moderada \\
\hline 3 & Fuerte \\
\hline 4 & Muy fuerte \\
\hline
\end{tabular}

Fuente: Balbi (2014). Elaboración: Propia 
En el ejercicio, con los valores de dependencia y de motricidad obtenidos de modo agregado para cada una de las variables (ver Anexo 3), se las mapeó en un diagrama de motricidad versus dependencia (Gráfico $3)$.

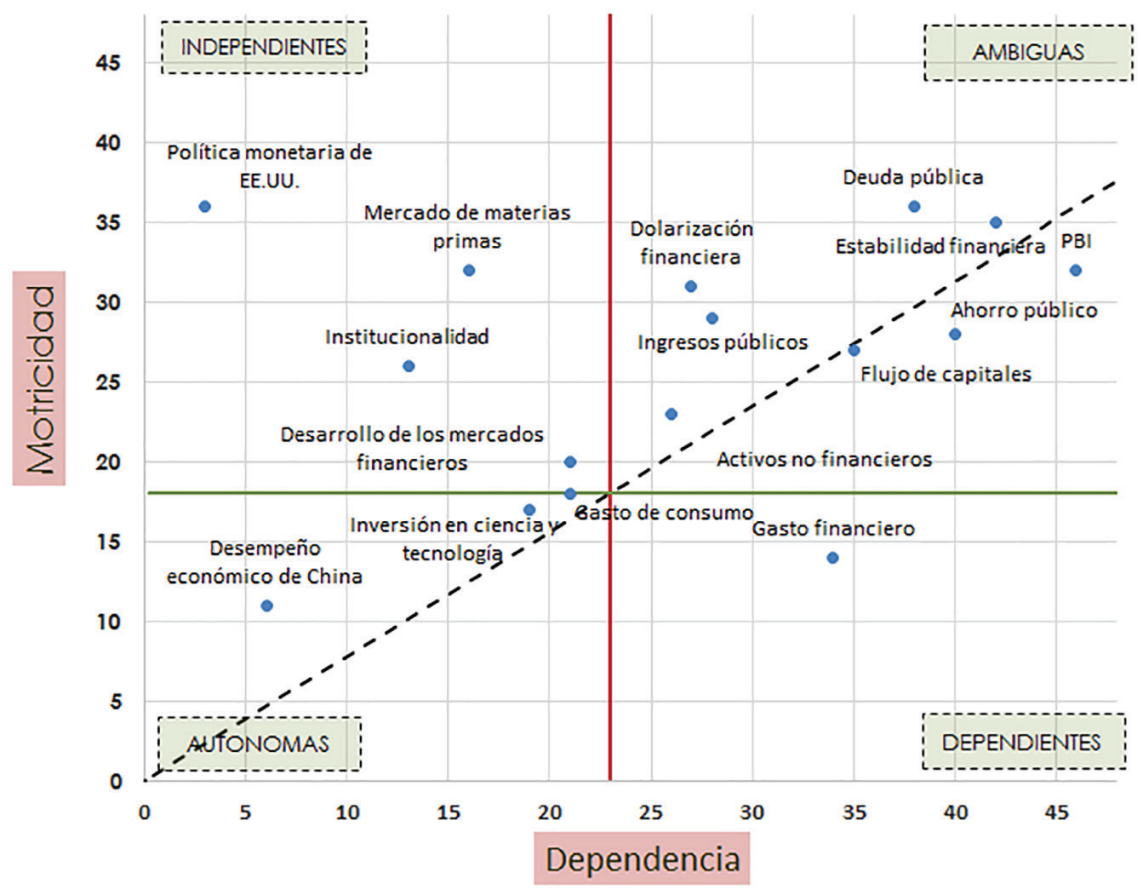

Gráfico 3. Análisis de motricidad y dependencia de variables

Fuente: MEF (2015a). Elaboración: Propia

\section{F. Selección de variables estratégicas}

Según Balbi (2014, p. 76-77), para este paso, en función de los puntajes obtenidos de la matriz, los cuatro cuadrantes donde se pueden ubicar las variables estratégicas son:

- Arriba y a la izquierda: el cuadrante de las variables e indicadores "independientes", es decir, los de mayor motricidad y de nula o muy poca dependencia. En este caso, todas esas variables quedarán seleccionadas por su motricidad. 
- Abajo y a la izquierda: son las "autónomas", pues son muy poco motrices y muy poco dependientes, poco lo que no se consideran en el análisis posterior.

- Abajo y a la derecha: son las "dependientes", como en los principios fundamentales de investigación, se eliminan, pues son "motorizadas" por las seleccionadas en primer lugar.

- Arriba y a la derecha: son las "ambiguas", pues tienen significativa motricidad y también dependencia. En este caso particular se procede según se hallen sobre (a la izquierda) o bajo (a la derecha) la diagonal:

a) Todas las variables e indicadores que están a la izquierda (hacia el eje vertical de motricidad) de ella, son más motrices que dependientes, y todas las que están a la derecha de la diagonal, son más dependientes que motrices.

b) La longitud de la perpendicular que sale desde la diagonal hasta la variable, nos indica cuánto es más motriz o dependiente, según esté a la izquierda o derecha respectivamente, es decir, a segmento perpendicular mayor, también mayor es el peso de motricidad o dependencia.

Así, condicionado al criterio final de los expertos y especialistas, de este cuadrante se seleccionan todas las que están a la izquierda de la diagonal y sobre ella, y también puede seleccionarse alguna que esté cerca de la diagonal, pero en el sector a la derecha de la diagonal. Esto nos permitirá seleccionar fácilmente las variables de mayor motricidad y menor dependencia.

En el ejercicio, se observó que en el cuadrante "independientes" estaban las variables de política monetaria de EEUU, institucionalidad, mercado de materias primas y el desarrollo de los mercados financieros, mientras que en el cuadrante "dependientes" estaba gasto financiero. Asimismo, en el cuadrado "ambiguas", pero a la izquierda de la diagonal, se hallaban deuda pública, dolarización financiera, ingresos públicos y estabilidad financiera, en tanto que las que se encontraban a la derecha de la diagonal eran PIB, flujo de capitales, ahorro público, activos no 
financieros y gasto de consumo. Por tanto, las variables estratégicas fueron seleccionadas tomando en cuenta:

- Puntaje obtenido de cada variable.

- Ubicación de las variables en cada uno de los 4 cuadrantes mencionados.

- Relevancia en opinión de expertos y especialistas para mejorar/ desmejorar la calificación de riesgo soberano.

Del proceso ordinario de selección se observó que algunas variables importantes se encontraban fuera del alcance de las políticas de gestión financiera de la Hacienda Pública, por ser exógenas; sin embargo, a juicio experto tenían utilidad para las acciones estratégicas de prevención del impacto que puedan causar sobre las otras variables (Cuadro 6). Asimismo, como parte del diagnóstico para efectuar la selección de variables estratégicas, también resulta conveniente identificar en un anexo a los actores internos y externos que influyan sobre cada una y a los actores que se vean afectados por cada variable, lo que para los efectos de este documento no resultó pertinente. La identificación de organización y funciones involucradas también sirve para ver qué procesos y normas podrían requerir acciones de mejora actual o futura.

\section{Cuadro 6.}

Variables estratégicas seleccionadas

\begin{tabular}{|c|c|}
\hline № & Variable \\
\hline 1 & Producto interno bruto \\
\hline 2 & Institucionalidad \\
\hline 3 & Desarrollo de mercados financieros \\
\hline 4 & Estabización financiera \\
\hline 5 & Deuda pública \\
\hline 6 & Ahorro público \\
\hline 8 & Ingreso público \\
\hline 11 & Flujo de capitales \\
\hline 15 & Política monetaria de los EEUU \\
\hline 16 & \\
\hline
\end{tabular}

Fuente: MEF (2015a). Elaboración: Propia 


\section{G. Diagnósticos básicos de pasado y presente}

Seleccionadas las variables estratégicas con sus indicadores más representativos, en este paso se debe planificar una adecuada, económica y eficiente búsqueda de la información estrictamente necesaria acerca de cada una de ellas y evitar caer en el riesgo de desinformación por saturación de información (Balbi 2010, p. 40-43). El objetivo es conocer la evolución pasada de cada variable, con sus datos y aspectos más significantes, y conocer con precisión el estado actual de cada una de ellas para poder fundamentar el diagnóstico de su evolución histórica y sustentar su tendencia para los próximos años. Sólo se usa la información de valor estratégico para cada variable y esta información debe permitir hacer la proyección (series de tiempo) o pronóstico (juicios expertos) de los indicadores de cada variable.

En cualquier caso, el ideal es poder reconstruir el valor pasado de cada uno de los indicadores relacionados y el último disponible respecto de la fecha de análisis para poder explicar el comportamiento mostrado por cada variable estratégica en el pasado y hacer el diagnóstico escrito de su situación actual y del origen de su situación crítica identificada, en caso exista. Desafortunadamente no existe un procedimiento estándar de este paso para todas las variables.

Los resultados pasados y presentes para los indicadores del ejercicio, que se utilizaron luego para construir el escenario tendencial, se muestran en el Cuadro 7.

\section{Cuadro 7.}

Evolución de indicadores por cada variable estratégica

\begin{tabular}{|c|c|c|c|c|c|c|c|c|c|c|c|}
\hline $\begin{array}{l}\text { Variable } \\
\text { estratégica }\end{array}$ & Indicador & $\begin{array}{l}\text { Año } \\
2005\end{array}$ & $\begin{array}{c}\text { Año } \\
2006\end{array}$ & $\begin{array}{c}\text { Año } \\
2007\end{array}$ & $\begin{array}{l}\text { Año } \\
2008\end{array}$ & $\begin{array}{l}\text { Año } \\
2009\end{array}$ & $\begin{array}{l}\text { Año } \\
2010\end{array}$ & $\begin{array}{l}\text { Año } \\
2011\end{array}$ & $\begin{array}{l}\text { Año } \\
2012\end{array}$ & $\begin{array}{l}\text { Año } \\
2013\end{array}$ & $\begin{array}{l}\text { Año } \\
2014\end{array}$ \\
\hline $\begin{array}{l}\text { Producto interno } \\
\text { bruto }\end{array}$ & $\begin{array}{l}\text { PIB per cápita } \\
\text { PPA }\end{array}$ & 6800 & 7422 & 8099 & 8875 & 8899 & 9620 & 10292 & 10931 & 11556 & 11817 \\
\hline Institucionalidad & $\begin{array}{l}\text { Nivel de } \\
\text { institucionalidad }\end{array}$ & n.d. & 3,25 & 3,30 & 3,45 & 3,52 & 3,52 & 3,54 & 3,44 & 3,36 & 3,26 \\
\hline \multirow{2}{*}{$\begin{array}{l}\text { Desarrollo } \\
\text { de mercados } \\
\text { financieros }\end{array}$} & $\begin{array}{l}\text { Saldos bonos } \\
\text { privados y } \\
\text { públicos en } \\
\text { moneda local / } \\
\text { PIB \% } \\
\end{array}$ & 5,9 & 6,0 & 9,2 & 8,8 & 9,4 & 9,9 & 9,2 & 9.4 & 9,5 & 10,6 \\
\hline & $\begin{array}{l}\text { Diferencial de } \\
\text { tasas de interés } \\
\text { activas y pasivas } \\
(\%)\end{array}$ & 21 & 20 & 19 & 19 & 18 & 17 & 16 & 17 & 14 & 13 \\
\hline
\end{tabular}


Pensamiento Crítico Vol. 22. $\mathrm{N}^{\circ} 2$

\begin{tabular}{|c|c|c|c|c|c|c|c|c|c|c|c|}
\hline $\begin{array}{l}\text { Variable } \\
\text { estratégica }\end{array}$ & Indicador & $\begin{array}{c}\text { Año } \\
2005\end{array}$ & \begin{tabular}{|l|} 
Año \\
2006
\end{tabular} & $\begin{array}{c}\text { Año } \\
2007\end{array}$ & \begin{tabular}{|l} 
Año \\
2008
\end{tabular} & $\begin{array}{l}\text { Año } \\
2009\end{array}$ & $\begin{array}{l}\text { Año } \\
2010\end{array}$ & $\begin{array}{l}\text { Año } \\
2011\end{array}$ & $\begin{array}{l}\text { Año } \\
2012\end{array}$ & $\begin{array}{c}\text { Año } \\
2013\end{array}$ & $\begin{array}{l}\text { Año } \\
2014\end{array}$ \\
\hline $\begin{array}{l}\text { Dolarización } \\
\text { financiera }\end{array}$ & $\begin{array}{l}\text { Depósitos } \\
\text { bancarios } \\
\text { en dólares } \\
\text { / Depósitos } \\
\text { bancarios totales }\end{array}$ & 67,2 & 62,7 & 59,3 & 58,0 & 55,8 & 47,8 & 47,3 & 41,6 & 47,4 & 47,0 \\
\hline $\begin{array}{l}\text { Estabilidad } \\
\text { financiera }\end{array}$ & $\begin{array}{l}\text { Desviación } \\
\text { estándar de } \\
\text { rendimiento a } 10 \\
\text { años del Tesoro } \\
\text { (pb) }\end{array}$ & 72 & 58 & 26 & 99 & 68 & 23 & 43 & 54 & 71 & 39 \\
\hline \multirow{3}{*}{ Deuda pública } & $\begin{array}{l}\text { Deuda / Ingresos } \\
\text { GC (\%) }\end{array}$ & 222,0 & 161,5 & 135,6 & 120,8 & 136,8 & 116,4 & 98,0 & 88,2 & 85,4 & 89,7 \\
\hline & $\begin{array}{l}\text { Deuda externa / } \\
\text { Deuda total GC } \\
(\%)\end{array}$ & 83,8 & 81,9 & 72,8 & 72,5 & 70,5 & 63,3 & 61,7 & 57,9 & 54,4 & 50,1 \\
\hline & $\begin{array}{l}\text { Pago de intereses } \\
\text { / Ingresos (\%) }\end{array}$ & 10,3 & 9,1 & 8,4 & 7,3 & 6,7 & 5,7 & 5,3 & 4,8 & 4,9 & 4,9 \\
\hline Ahorro público & \begin{tabular}{|l} 
Activos \\
financieros / \\
Gastos del GC \\
$(\%)$ \\
\end{tabular} & 17,3 & 24,3 & 29,2 & 38,3 & 38,5 & 41,2 & 47,1 & 57,3 & 57,4 & 57,6 \\
\hline \multirow{2}{*}{ Ingreso público } & \begin{tabular}{|l} 
Ingresos \\
tributarios GC / \\
PIB (\%)
\end{tabular} & 14,4 & 15,9 & 16,4 & 16,4 & 14,4 & 15,4 & 16,1 & 16,5 & 16,3 & 16,5 \\
\hline & \begin{tabular}{|l} 
Ingresos no \\
tributarios GC / \\
PIB (\%)
\end{tabular} & 2,2 & 2,5 & 2,6 & 2,7 & 2,3 & 2,4 & 2,7 & 2,6 & 2,5 & 2,4 \\
\hline $\begin{array}{l}\text { Mercado de } \\
\text { materias primas }\end{array}$ & $\begin{array}{l}\text { Índice de precios } \\
\text { de materias } \\
\text { primas }\end{array}$ & 106,0 & 120,9 & 156,8 & 98,3 & 140,9 & 174,9 & 184,0 & 182,5 & 184,3 & 130,8 \\
\hline Flujo de capitales & $\begin{array}{l}\text { Balanza en } \\
\text { cuenta corriente } \\
\text { / PIB (\%) }\end{array}$ & $+1,5$ & $+3,3$ & $+1,5$ & $-4,3$ & $-0,5$ & $-2,4$ & $-1,9$ & $-2,7$ & $-4,4$ & $-4,0$ \\
\hline $\begin{array}{l}\text { Política } \\
\text { monetaria de } \\
\text { EEUU }\end{array}$ & $\begin{array}{l}\text { Tasa de } \\
\text { referencia de la } \\
\text { Reserva Federal }\end{array}$ & 4,25 & 5,25 & 4,25 & 0,25 & 0,25 & 0,25 & 0,25 & 0,25 & 0,25 & 0,25 \\
\hline
\end{tabular}

Fuentes: BCRP, MEF, INEI, SBS, FMI, Moody's y Bloomberg. Elaboración: Propia

\section{H. Construcción de escenarios}

En este paso el análisis requiere la construcción de escenarios futuros alternativos que permitan analizar, retrospectivamente desde el añofuturo elegido, el cambio que se debería haber generado en el comportamiento de las variables estratégicas para llegar allí, con sus respectivos riesgos y oportunidades, a fin de tomar posteriormente las decisiones y acciones 
que efectivamente permitan desde el presente real construir la apuesta del futuro que se elija como el más deseado (Gráfico 4).

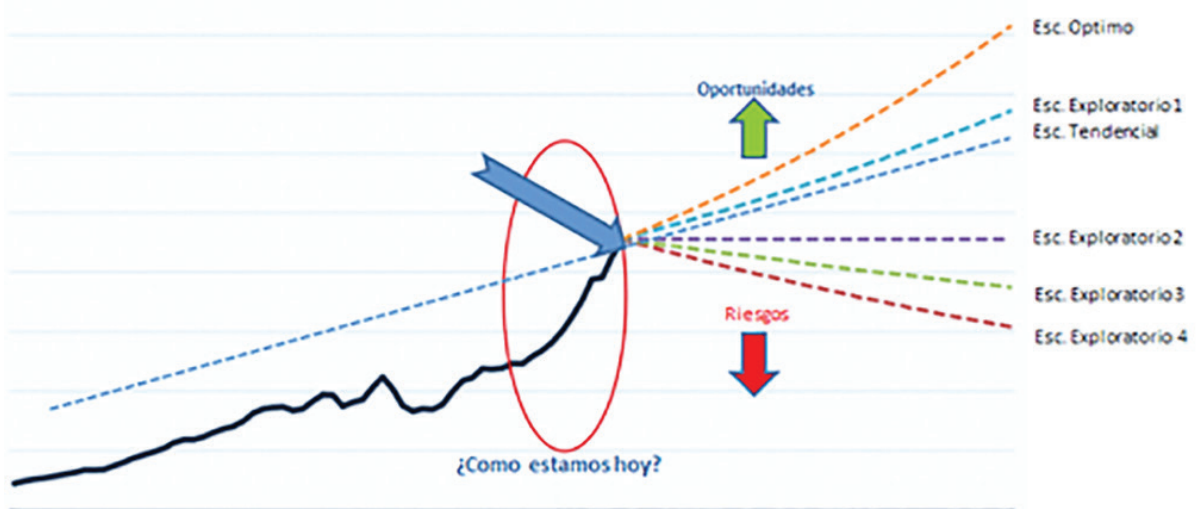

Gráfico 4. Definición de escenarios exploratorios y escenario apuesta Fuentes: CEPLÁN (2014a). Elaboración: Propia

En este ejercicio, la elección de los escenarios desfavorables fue crucial, pues, se trató de escenarios sobre dos de las variables estratégicas exógenas que más han solido afectar el desempeño económico del Perú y tener un comportamiento bastante especulativo, en un caso, y discrecional, en el otro. Como se indicó, se definieron tres escenarios exploratorios con horizonte al año 2030, uno positivo, uno negativo y uno de estrés, además de la definición de un escenario óptimo y un escenario tendencial:

i) Escenario óptimo, que sirve como patrón referencial de calidad, y como base fija para comparaciones y analogías, independientemente de que sea factible alcanzarlo, pero sin que llegue a ser imposible o utópico;

ii) Escenario base, donde se hace un análisis tendencial para cada variable estratégica, donde se asume que se continúa haciendo lo mismo que en los últimos años, sin algún cambio adicional;

iii) Escenario exploratorio A (positivo), donde Perú llega a formar parte de la OCDE;

iv) Escenario exploratorio B (negativo), donde se enfrenta una caída de los precios de la materias primas en $50 \%$; y 
v) Escenario exploratorio C (estrés), donde la tasa de referencia de la política monetaria en los EEUU sube al 5\%.

\section{Escenario óptimo}

Según Balbi (2010, p. 43), la pregunta orientadora en este paso es ¿cuál sería el estado de futuro óptimo, pero dentro de valores ideales y lógicos, independientemente de que sea factible alcanzarlo? Así, el escenario óptimo a construirse debe permitir delimitar una meta ideal y lógica para cada indicador representativo de las variables estratégicas seleccionadas y, además, servir como punto de comparación y análisis para los otros escenarios. Por tanto, los valores que alcancen los indicadores de cada variable tendrán una calificación cualitativa de 10 y, a partir de ello, luego se realizará el análisis comparativo.

\section{Cuadro 8.}

Construcción del escenario óptimo

\begin{tabular}{|c|c|c|c|}
\hline $\begin{array}{c}\text { Variable } \\
\text { estratégica }\end{array}$ & Indicador & Calificación & Escenario ideal \\
\hline $\begin{array}{l}\text { Producto interno } \\
\text { bruto }\end{array}$ & $\begin{array}{c}\text { PIB per cápita } \\
\text { PPA }\end{array}$ & 10 & $\begin{array}{l}\text { Se alcanza los US\$ } 29 \text { 205, el promedio de las } \\
\text { medianas de países AAA-A de la OCDE en 2005- } \\
\text { 2014. Brasil, México y Colombia registraron un } \\
\text { PIB per cápita promedio de US\$15 } 456 \text { en el año } \\
\text { 2014 y Chile en el mismo periodo registró un } \\
\text { nivel de US\$22 } 971 \text {. }\end{array}$ \\
\hline Institucionalidad & $\begin{array}{c}\text { Nivel de } \\
\text { institucionalidad }\end{array}$ & 10 & $\begin{array}{l}\text { Se alcanza un 5,68, que es el promedio de países } \\
\text { AAA entre los años 2005-2014, países que } \\
\text { pertenecen a la OCDE. }\end{array}$ \\
\hline \multirow{3}{*}{ Deuda pública } & $\begin{array}{l}\text { Deuda / Ingresos } \\
\text { GC }\end{array}$ & 10 & $\begin{array}{l}\text { Se alcanza un } 68,0 \% \text {, que es el promedio de } \\
\text { países AAA como Nueva Zelanda, Noriega, } \\
\text { Australia y Dinamarca entre los años 2005-2014, } \\
\text { países que pertenecen a la OCDE. }\end{array}$ \\
\hline & $\begin{array}{l}\text { Deuda externa } \\
\text { / Total deuda } \\
\text { del GC }\end{array}$ & 10 & $\begin{array}{l}\text { Se alcanza un } 1,4 \% \text {, que es el nivel de Nueva } \\
\text { Zelanda, economía pequeña y abierta de la } \\
\text { OCDE, para } 2013 \text {. }\end{array}$ \\
\hline & $\begin{array}{l}\text { Pago de intereses } \\
\text { / Ingresos GC }\end{array}$ & 10 & $\begin{array}{l}\text { Se alcanza un 3,0\%, que es el promedio de países } \\
\text { AAA como Nueva Zelanda, Noriega, Australia y } \\
\text { Dinamarca entre los años 2005-2014, países que } \\
\text { pertenecen a la OCDE. }\end{array}$ \\
\hline \multirow{2}{*}{ Ingreso público } & $\begin{array}{l}\text { Ingresos } \\
\text { tributarios GC/ } \\
\text { PIB }\end{array}$ & 10 & $\begin{array}{l}\text { Se alcanza un } 26,3 \% \text { del PIB, que es el promedio } \\
\text { de los países europeos, miembros de OCDE en el } \\
\text { periodo } 2010-2012 \text {. }\end{array}$ \\
\hline & $\begin{array}{l}\text { Ingresos no } \\
\text { tributarios GC } \\
\text { / PIB }\end{array}$ & 10 & $\begin{array}{l}\text { Se alcanza un } 19,0 \% \text {, que corresponde al } \\
\text { promedio anual de los países europeos de la } \\
\text { OCDE, tomando el periodo } 2010-2012 \text {. }\end{array}$ \\
\hline
\end{tabular}




\begin{tabular}{|c|c|c|l|}
\hline $\begin{array}{c}\text { Variable } \\
\text { estratégica }\end{array}$ & Indicador & Calificación & \multicolumn{1}{|c|}{ Escenario ideal } \\
\hline Ahorro público & $\begin{array}{c}\text { Activos } \\
\text { financieros / } \\
\text { Gastos del GC }\end{array}$ & 10 & $\begin{array}{l}\text { Se alcanza un nivel de 100\%, de tal manera que } \\
\text { los activos financieros puedan cubrir los gastos } \\
\text { públicos de un año ante cualquier desastre } \\
\text { que, de otro modo, le obligaría incurrir en un } \\
\text { nivel de gasto que le deterioraría su calificación } \\
\text { soberana por incurrir en un desesperado mayor } \\
\text { endeudamiento. }\end{array}$ \\
\hline $\begin{array}{c}\text { Desarrollo de } \\
\text { los mercados } \\
\text { financieros }\end{array}$ & $\begin{array}{c}\text { Saldo de bonos } \\
\text { públicos y } \\
\text { privados en } \\
\text { moneda local } \\
\text { / PIB }\end{array}$ & 10 & $\begin{array}{l}\text { El indicador de saldo de deuda pública y privada } \\
\text { emitida en moneda nacional sería de 50\% } \\
\text { respecto al PIB, similar cifra a la alcanzada por } \\
\text { Chile a diciembre 2014. }\end{array}$ \\
\cline { 2 - 4 } & $\begin{array}{c}\text { Diferencial tasas } \\
\text { activasy pasivas }\end{array}$ & 10 & $\begin{array}{l}\text { Se alcanza un diferencial de tasas de interés } \\
\text { de 2\%, nivel cercano al de los países de la AAA } \\
\text { pertenecientes a la OCDE. }\end{array}$ \\
\hline $\begin{array}{c}\text { Estabilidad } \\
\text { financiera }\end{array}$ & $\begin{array}{c}\text { Desviación } \\
\text { estándar de } \\
\text { rendimiento a 10 } \\
\text { años del Tesoro }\end{array}$ & 10 & $\begin{array}{l}\text { Se alcanza una desviación estándar de 18 puntos } \\
\text { básicos (0,18\%), que es el indicador mínimo } \\
\text { anual entre 2000-2013 de Estados Unidos, país } \\
\text { con calificación AAA que pertenece a la OCDE } \\
\text { y que cuenta con un mercado desarrollado de } \\
\text { bonos de deuda pública. }\end{array}$ \\
\hline $\begin{array}{c}\text { Dolarización } \\
\text { financiera }\end{array}$ & $\begin{array}{c}\text { Depósitos } \\
\text { bancarios } \\
\text { en dólares } \\
\text { / Depósitos } \\
\text { bancarios totales }\end{array}$ & 10 & $\begin{array}{l}\text { Se alcanza un 6,5\%, que es el nivel de Nueva } \\
\text { Zelanda, economía pequeña y abierta de la } \\
\text { OcDE, para el año 2014. }\end{array}$ \\
\hline
\end{tabular}

Fuente: MEF (2015a). Elaboración: Propia

En el ejercicio, dado que a fines de 2014 se oficializó el lanzamiento del Programa País de la OCDE con el Perú, para establecer los indicadores óptimos se tomaron como referencias los mejores resultados logrados por países que pertenecen a dicha organización, países con una calificación de riesgo soberano superior al máximo histórico de "A-" con que cuenta la deuda soberana en moneda local del Perú desde 2014 con 4 de 5 agencias calificadoras de riesgo internacionales. En el Cuadro 8 se describe la situación óptima.

En el escenario actual el valor de todos los indicadores estuvo por debajo del óptimo, pero se observaron algunos casos críticos que tienen incluso una calificación menor de 5, como el nivel de PIB per capita, la institucionalidad, los ingresos tributarios y no tributarios (que influyen directamente en la capacidad de pago soberano), así como la deuda emitida en moneda nacional (debido a la alta deuda externa). Por el lado 
de los pasivos financieros, se aprecia que los indicadores relacionados con la deuda del gobierno central se encontraban con una calificación de entre 5 y 8, mientras que por el lado de los activos financieros muestra que la variable ahorro público registraba una calificación de 6. Estos niveles alcanzados en los últimos años se han reflejado en las mejoras sistemáticas de la calificación de riesgo soberano entre 2011 y 2014; no obstante, en adelante podrían mejorar o empeorar en función a los escenarios futuros alternativos, desencadenando un riesgo o generando una oportunidad respectivamente.

\section{J. Escenario base (análisis tendencial)}

Según Balbi (2010, p.47), "este paso del método es muy importante, pues, sus productos se convertirán en las matrices de simulación, seguimiento y actualización de todo el proceso, incluido la supervisión que se haga durante la implementación de estrategia y planes". El escenario tendencial es el que no contempla la posibilidad de tomar alguna acción adicional diferente a las ya tomadas ni cambios nuevos en la evolución del entorno, es decir, se estima el desarrollo de cada indicador de acuerdo a su tendencia histórica. Los resultados obtenidos son considerados como el escenario base. Así, se parte de los diagnósticos de evolución histórica, situación actual y escenario óptimo obtenidos en los pasos anteriores y a continuación se procede a elaborar las tendencias utilizando las herramientas y técnicas prospectivas (ver Cuadro 1) sobre la base de los datos históricos y presentes ya relevados. Con los resultados obtenidos para cada indicador, se procede a calificar con una nota de 0 a 10 usando como referencia el escenario óptimo.

Además, este paso da suficiente información de valor estratégico como para obtener los primeros mapas de riesgos y oportunidades que a futuro podrían develarse a partir de los efectos que las variables estratégicas en el año 2030 podrían tener sobre nuestros objetivos, metas e intereses. Del análisis de la interacción entre los efectos positivos y negativos de la evolución tendencial de cada variable se obtienen los riesgos y oportunidades a futuro. Para ello, bajo el criterio de influencia, se considera su magnitud, sentido y resultado estratégico de la interacción. 


\section{Cuadro 9.}

Construcción del escenario base

\begin{tabular}{|c|c|c|c|}
\hline $\begin{array}{l}\text { Variable } \\
\text { estratégica }\end{array}$ & Indicador & Calificación & Escenario tendencial $^{4}$ \\
\hline $\begin{array}{l}\text { Producto interno } \\
\text { bruto }\end{array}$ & PIB per cápita PPA & 5 & $\begin{array}{l}\text { Se alcanza los US\$16 606 consideran para } \\
\text { la proyección el periodo 1990-2014 y los } \\
\text { quiebres temporales de los años } 1992 \text { y } \\
1998 .\end{array}$ \\
\hline Institucionalidad & $\begin{array}{l}\text { Nivel de } \\
\text { institucionalidad }\end{array}$ & 2 & $\begin{array}{l}\text { Se alcanza un nivel de 3,31 en el año } 2030 \\
\text { utilizando como muestra el periodo } 2006 \text { - } \\
\text { 2014, considerando el cambio de tendencia } \\
\text { del año } 2012 .\end{array}$ \\
\hline \multirow{3}{*}{ Deuda pública } & Deuda / Ingresos GC & 9 & $\begin{array}{l}\text { Se alcanza un nivel de } 85,7 \% \text { en el año } 2030 \\
\text { utilizando como muestra el periodo } 2005- \\
2014 \text {, considerando el cambio de tendencia } \\
\text { del año } 2008 \text {. }\end{array}$ \\
\hline & $\begin{array}{l}\text { Deuda externa / } \\
\text { Total deuda del GC }\end{array}$ & 6 & $\begin{array}{l}\text { Se alcanza un } 36,4 \% \text { del total de la } \\
\text { deuda, tomando en cuenta los cambios de } \\
\text { tendencia observados en los años } 2006 \text { y } \\
2009 \text { para el periodo } 2002-2014 \text {. }\end{array}$ \\
\hline & $\begin{array}{l}\text { Pago de intereses / } \\
\text { Ingresos }\end{array}$ & 9 & $\begin{array}{l}\text { Se alcanza un } 4,0 \% \text {, tomando en cuenta la } \\
\text { variación móvil de los últimos tres periodos, } \\
\text { para la muestra de } 2002-2014 \text {. }\end{array}$ \\
\hline \multirow[t]{2}{*}{ Ingresos públicos } & $\begin{array}{l}\text { Ingresos tributarios } \\
\text { GC / PIB }\end{array}$ & 4 & $\begin{array}{l}\text { Se alcanza un nivel de } 16,7 \% \text { del PIB, } \\
\text { tomando en cuenta cambios de tendencia } \\
\text { observados en } 1999 \text { y } 2009 \text {. }\end{array}$ \\
\hline & $\begin{array}{l}\text { Ingresos no } \\
\text { tributarios GC / PIB }\end{array}$ & 1 & $\begin{array}{l}\text { Se alcanza un nivel de } 2,9 \% \text { considerando el } \\
\text { periodo de } 2005-2014 \text {. }\end{array}$ \\
\hline Ahorro público & $\begin{array}{l}\text { Activos financieros } \\
\text { / Gastos del GC }\end{array}$ & 6 & $\begin{array}{l}\text { El ratio de ahorro público se comportante } \\
\text { muy similar a lo apreciado en los últimos } \\
\text { años, por lo que, ajustando los pequeños } \\
\text { cambios tendenciales de los años } 2009 \text { y } \\
2012 \text {, se obtuvo un } 58,2 \%\end{array}$ \\
\hline \multirow{2}{*}{$\begin{array}{l}\text { Desarrollo de } \\
\text { los mercados } \\
\text { financieros }\end{array}$} & $\begin{array}{l}\text { Saldo de bonos } \\
\text { públicos y privados } \\
\text { / PIB }\end{array}$ & 2 & $\begin{array}{l}\text { Considerando el cambio de tendencia } \\
\text { observado en el año } 2011 \text { alcanza un nivel } \\
\text { de } 11,1 \% \text { utilizando como muestra el } \\
\text { periodo } 2002-2014 \text {. }\end{array}$ \\
\hline & $\begin{array}{l}\text { Diferencial de tasas } \\
\text { activas y pasivas } \%\end{array}$ & 7 & $\begin{array}{l}\text { Con la tendencia a la baja observada en los } \\
\text { últimos años se alcanza un a 9\% en el } 2030 \\
\text { considerando la muestra } 2000-2014 \text {. }\end{array}$ \\
\hline $\begin{array}{l}\text { Estabilidad } \\
\text { financiera }\end{array}$ & $\begin{array}{l}\text { Desviación estándar } \\
\text { de rendimiento a } 10 \\
\text { años del Tesoro }\end{array}$ & 5 & $\begin{array}{l}\text { Se llega a un nivel de } 55 \text { puntos básicos } \\
\text { considerando la muestra 2005-2014. }\end{array}$ \\
\hline $\begin{array}{l}\text { Dolarización } \\
\text { financiera }\end{array}$ & $\begin{array}{l}\text { Depósitos bancarios } \\
\text { en dólares / } \\
\text { Depósitos bancarios } \\
\text { totales }\end{array}$ & 8 & $\begin{array}{l}\text { Con la tendencia a la baja observada en los } \\
\text { últimos años se alcanza un a 23,6\% en el } \\
2030 \text { considerando el periodo } 1993-2014 \text {. }\end{array}$ \\
\hline
\end{tabular}

Fuente: MEF (2015a). Elaboración: Propia

${ }^{4}$ Los modelos de proyección incluyeron métodos no estacionales como promedio móvil simple, suavizado exponencial simple, promedio móvil simple y el suavizado exponencial doble y los métodos de promedio móvil autorregresivo integrado (ARIMA), entre otros. 
Pensamiento Crítico Vol. 22. №²

Cuadro 10.

Riesgos y oportunidades en el escenario base

\begin{tabular}{|c|c|}
\hline Riesgos & Oportunidades \\
\hline \multicolumn{2}{|c|}{ Producto interno bruto } \\
\hline $\begin{array}{l}\text { Se revierten las condiciones externas } \\
\text { favorables que prevalecieron en el mercado } \\
\text { de materias primas en la última década. } \\
\text { Los planes de diversificación productiva no } \\
\text { llegan a cambiar el modelo de desarrollo } \\
\text { del país. } \\
\text { No se terminan de implementar planes } \\
\text { para mejorar la competitividad del país. }\end{array}$ & $\begin{array}{l}\text { Fortalecimiento del cumplimiento con } \\
\text { las políticas públicas de los últimos años } \\
\text { asegura su credibilidad y mejora su } \\
\text { reputación. } \\
\text { Se crean más mecanismos para alentar un } \\
\text { clima favorable al crecimiento sostenido de } \\
\text { la inversión privada. } \\
\text { Se mejoran los sistemas de control interno } \\
\text { para el cumplimiento de los planes } \\
\text { estratégicos del Estado. }\end{array}$ \\
\hline \multicolumn{2}{|c|}{ Institucionalidad } \\
\hline $\begin{array}{l}\text { La poca mejora de este indicador afecta } \\
\text { credibilidad e impide obtener una mejor } \\
\text { calificación de riesgo soberano. } \\
\text { Aumenta el nivel de corrupción por falta de } \\
\text { mejoras en los sistemas de control interno. } \\
\text { Aumenta la volatilidad de la inflación, lo } \\
\text { que reduce la credibilidad y efectividad de } \\
\text { las políticas macroeconómicas. }\end{array}$ & $\begin{array}{l}\text { Establecimiento de planes de cierre de las } \\
\text { brechas respecto a los países con mejores } \\
\text { prácticas. } \\
\text { Se sientan las bases institucionales para } \\
\text { una mayor y mejor comunicación entre } \\
\text { todos los niveles de gobierno. } \\
\text { Introducción de cambios regulatorios } \\
\text { para reducir o mitigar mejor las fallas de } \\
\text { mercado. }\end{array}$ \\
\hline \multicolumn{2}{|c|}{ Deuda pública } \\
\hline $\begin{array}{l}\text { Mayor déficit hace que deuda crezca a } \\
\text { mayor ritmo que los ingresos reduciendo la } \\
\text { capacidad de pago de la República. } \\
\square \text { Pierde prioridad el desarrollo del mercado } \\
\text { de deuda en soles, afectando al mercado de } \\
\text { capitales doméstico. } \\
\text { Asunción de primas de emisión más } \\
\text { altas por operaciones más grandes en los } \\
\text { mercados internacionales. } \\
\text { Cambio de políticas desatiende necesidades } \\
\text { de calce de inversión de algunos nichos de } \\
\text { mercado en curva soberana. }\end{array}$ & $\begin{array}{l}\text { Impulso al desarrollo del mercado de } \\
\text { deuda en soles con el desarrollo de un } \\
\text { eficiente mercado de operaciones de } \\
\text { reporte. } \\
\text { Bajas primas de emisión por subastas más } \\
\text { frecuentes de valores de deuda pública en } \\
\text { soles para mejorar estructura de deuda. } \\
\text { Cumplimiento de calendario de subastas } \\
\text { permite mayor credibilidad a la formación } \\
\text { de precios de bonos no líquidos. } \\
\text { Mayor difusión de los instrumentos de deuda } \\
\text { pública en soles permite un crecimiento de la } \\
\text { base de inversionistas locales. }\end{array}$ \\
\hline \multicolumn{2}{|c|}{ Ingreso público } \\
\hline $\begin{array}{l}\text { Falta de reformas dificulta una mayor } \\
\text { recaudación para reducir las brechas y } \\
\text { obtener mejoras en la calificación soberana. } \\
\text { Menores ingresos no permiten visionar un } \\
\text { mayor gasto en rubros significativos para } \\
\text { la mejor calidad de vida de la ciudadanía } \\
\text { como el de más obras públicas. }\end{array}$ & $\begin{array}{l}\text { Cambio significativo de las políticas para } \\
\text { incrementar los ingresos públicos en los } \\
\text { tres niveles de gobierno. } \\
\text { Mejoras para ampliar la base tributaria y } \\
\text { reducir la informalidad } \\
\text { Se hacen cruces de información bancaria } \\
\text { y de valores para reducir la elusión y la } \\
\text { evasión tributaria. }\end{array}$ \\
\hline
\end{tabular}




\begin{tabular}{|c|c|}
\hline Riesgos & Oportunidades \\
\hline \multicolumn{2}{|c|}{ Ahorro público } \\
\hline $\begin{array}{l}\text { No se toman medidas para continuar } \\
\text { generando ahorro ante cambios en el } \\
\text { contexto favorable de los últimos } 10 \text { años. } \\
\text { Gasto del ahorro público con visión de } \\
\text { corto plazo debilita la capacidad de pago de } \\
\text { la deuda neta. }\end{array}$ & $\begin{array}{l}\text { Se ponen en marcha de políticas de mejora } \\
\text { en la gestión de caja dando énfasis en las } \\
\text { condiciones de corto plazo. } \\
\text { Se institucionaliza el manejo de reservas } \\
\text { de liquidez, en función a la evolución actual } \\
\text { y esperada de la estructura de balance. }\end{array}$ \\
\hline \multicolumn{2}{|c|}{ Desarrollo de los mercados financieros } \\
\hline $\begin{array}{l}\text { Tendencia del tamaño del mercado de } \\
\text { bonos en soles no cambia, limitando } \\
\text { desarrollo de mercado de capitales. } \\
\text { Mayor concentración bancaria genera } \\
\text { poder de mercado que revierte tendencia a } \\
\text { la baja del diferencial de tasas de interés. } \\
\text { Baja oferta de bonos en moneda nacional } \\
\text { obliga a incrementar la dolarización de las } \\
\text { pensiones por renta vitalicia. }\end{array}$ & $\begin{array}{l}\text { Mercado pequeño facilita la } \\
\text { implementación de procesos modernos } \\
\text { más acordes a los que usan en economías } \\
\text { avanzados } \\
\text { Papel más activo de las entidades } \\
\text { financieras del Estado bajo estándares } \\
\text { internacionales como los de la OCDE. } \\
\text { Mayor desarrollo del mercado de bonos } \\
\text { genera competencia y ayuda a reducir el } \\
\text { diferencial de tasas de interés bancarias. }\end{array}$ \\
\hline \multicolumn{2}{|c|}{ Estabilidad financiera } \\
\hline $\begin{array}{l}\text { Alta participación de no residentes genera } \\
\text { mayor volatilidad ante subidas de tasas de } \\
\text { interés internacionales. } \\
\text { Se incrementan los límites de inversión en } \\
\text { el exterior a los fondos de pensiones, pese a } \\
\text { salida de no residentes. }\end{array}$ & $\begin{array}{l}\text { Participación directa del Tesoro en el } \\
\text { mercado de valores de deuda pública } \\
\text { ayuda a moderar escenarios de volatilidad. } \\
\text { Democratización del acceso al mercado de } \\
\text { deuda pública a todas las entidades como } \\
\text { efectivo activo libre de riesgo. }\end{array}$ \\
\hline \multicolumn{2}{|c|}{ Dolarización financiera } \\
\hline $\begin{array}{l}\text { Expectativas de una mayor depreciación del } \\
\text { sol evitan una mayor desdolarización. } \\
\text { Subidas del tipo de cambio generan } \\
\text { aumento de la morosidad que pone en } \\
\text { riesgo la solvencia del sector bancario. } \\
\text { Mayor vulnerabilidad externa frente a } \\
\text { economía no dolarizada. }\end{array}$ & $\begin{array}{l}\text { Mejorar regulación para generar mayores } \\
\text { incentivos para el uso del sol, como el uso } \\
\text { de un ITF asimétrico. } \\
\text { Mayor oferta de bonos en soles lleva a } \\
\text { satisfacer la mayor demanda por activos } \\
\text { invertibles generados por el crecimiento. } \\
\text { Aceleración de la sustitución del crédito en } \\
\text { dólares por soles. }\end{array}$ \\
\hline
\end{tabular}

Fuente: MEF (2015a). Elaboración: Propia

En el ejercicio, el escenario base es un análisis tendencial hacia el año 2030. Bajo este escenario, en 2030 el PIB per cápita peruano muestra un cambio importante respecto al que se tenía en el escenario actual, pese al menor crecimiento observado en el año 2014, así como lo que se espera para el cierre del año 2015 (Cuadro 9). Como no se hacen cambios estructurales, los ingresos públicos, tributarios y no tributarios, muestran un desempeño similar al del escenario actual. Por otro lado, 
la moderada evolución favorable de la desdolarización financiera va de la mano con la tendencia observada en los últimos años respecto a la desdolarización de la deuda del Gobierno Central. Asimismo, el indicador relacionado con los costos de transacción refleja la continuación de la mejora observada en los últimos 15 años, disminuyendo el diferencial de tasas de interés en casi 400 pb más. Los indicadores de deuda reflejan un comportamiento favorable en el escenario base respecto a la situación actual, especialmente en la disminución de la participación de la deuda externa que cae a un $36 \%$ y en el mantenimiento de la buena capacidad de pago soberana, aproximada por la proporción de deuda sobre sus ingresos con niveles de ahorro público similares a los actuales, lo que le permitiría obtener mejoras adicionales en la calificación de riesgo soberano. Por su parte, el análisis de riesgos y oportunidades para cada variable se detalla en el Cuadro 10. La estimación de indicadores se halla en el Anexo 4.

\section{K. Escenario exploratorio A (Perú forma parte de la OCDE)}

Para este paso, en el ejercicio se supone que el Perú ha incorporado grandes cambios estructurales que coadyuvan a disminuir las brechas con los países de la OCDE, según se describe en CEPLÁN (2015). Para ello, se impulsaron grandes reformas estructurales que vieron resultados en el corto, medio y largo plazos.

- Corto plazo: Se generó mayor valor agregado en actividades de manufactura y se logró un equilibrio ecológico en general más sostenible con fuentes de agua mejorada en zonas urbanas y rurales.

- Medio plazo: Se tomaron medidas políticas específicas que tuvieron efecto en la mejora del nivel del PIB per cápita, reducción de la dolarización financiera, menor deuda externa y mejor gestión de activos y pasivos del Gobierno.

- Largo plazo: Se tomaron medidas que iniciaron un cambio estructural, como fueron la efectividad gubernamental relacionada a una mejora de la institucionalidad, tamaño y estabilidad de mercados financieros, flujo de inversión extranjera directa y control de la corrupción. 


\section{Con los resultados obtenidos para cada indicador, se procede a calificar con una nota de 0 a 10 usando como referencia el escenario óptimo.}

\section{Cuadro 11.}

Construcción de escenario exploratorio A

\begin{tabular}{|c|c|c|c|}
\hline $\begin{array}{c}\text { Variable } \\
\text { estratégica }\end{array}$ & Indicador & Calificación & Escenario Perú forma parte de la OCDE \\
\hline $\begin{array}{l}\text { Producto interno } \\
\text { bruto }\end{array}$ & $\begin{array}{l}\text { PIB per cápita } \\
\text { PPA }\end{array}$ & 8 & $\begin{array}{l}\text { Los esfuerzos en materia de política económica } \\
\text { y financiera contribuyen al crecimiento del } \\
\text { producto per cápita que alcanza un nivel de } \\
\text { US\$ } 23064,100 \% \text { mayor que el escenario } \\
\text { actual. Este desempeño toma como referencia } \\
\text { el periodo menos favorable del indicador } \\
\text { óptimo de países con calificación AAA-A OCDE } \\
\text { 2005-2014 (año 2005). }\end{array}$ \\
\hline Institucionalidad & $\begin{array}{c}\text { Nivel de } \\
\text { institucionalidad }\end{array}$ & 7 & $\begin{array}{l}\text { Se perciben las mejoras institucionales, } \\
\text { entre ellas: i) mejora regulatoria, ii) mayor } \\
\text { articulación entre las entidades del Estado, } \\
\text { iii) implementación de medidas contra la } \\
\text { corrupción, entre otros. El indicador alcanza } \\
\text { un } 4.83 \text { tomando como referencia al país con } \\
\text { menor desempeño de la muestra tomada para } \\
\text { el óptimo (Estados Unidos). }\end{array}$ \\
\hline \multirow{3}{*}{ Deuda pública } & $\begin{array}{c}\text { Deuda / Ingresos } \\
\text { GC }\end{array}$ & 9 & $\begin{array}{l}\text { La capacidad de generar ingresos es mayor a } \\
\text { la demanda de gastos e inversiones, lo que se } \\
\text { traduce en un indicador de deuda respecto de } \\
\text { los ingresos del 82\%, tomando como referencia } \\
\text { a Nueva Zelanda (el país con menor desempeño } \\
\text { de la muestra para el óptimo). Chile, miembro } \\
\text { de la OCDE, registró un indicador de } 71 \% \text { en } \\
2014 \text {. }\end{array}$ \\
\hline & $\begin{array}{c}\text { Deuda externa } \\
\text { / Deuda total } \\
\text { del GC }\end{array}$ & 8 & $\begin{array}{l}\text { Se llega a tener como máximo un } 25,0 \% \text { de } \\
\text { deuda externa, tomando como referencia el } \\
\text { estudio empírico de Calvo, Izquierdo y Talvi } \\
\text { (2003) quienes calcularon el descalce entre } \\
\text { el sector transable y no transable de la deuda } \\
\text { pública y el PIB durante la crisis de los años } \\
\text { 90. Colombia, México y Brasil alcanzaron en } \\
\text { promedio un } 17,4 \% \text { en } 2014 \text {. }\end{array}$ \\
\hline & $\begin{array}{c}\text { Pago de intereses } \\
\text { / Ingresos }\end{array}$ & 9 & $\begin{array}{l}\text { El dinamismo del mercado de deuda pública } \\
\text { se compensa con una mayor recaudación de } \\
\text { ingresos, lo que permite registrar un indicador } \\
\text { de } 4,0 \% \text {, que toma como referencia el nivel } \\
\text { observado por Australia Dinamarca, Noruega y } \\
\text { Nueva Zelanda en el periodo 2001-2014. }\end{array}$ \\
\hline
\end{tabular}


Pensamiento Crítico Vol. 22. $\mathrm{N}^{\circ} 2$

\begin{tabular}{|c|c|c|c|}
\hline $\begin{array}{c}\text { Variable } \\
\text { estratégica }\end{array}$ & Indicador & Calificación & Escenario Perú forma parte de la OCDE \\
\hline \multirow{2}{*}{$\begin{array}{l}\text { Ingresos } \\
\text { públicos }\end{array}$} & $\begin{array}{l}\text { Ingresos } \\
\text { tributarios GC } \\
\quad / \text { PIB }\end{array}$ & 6 & $\begin{array}{l}\text { Los ingresos tributarios se incrementan } \\
\text { hasta un 20,3\% del PIB luego de las mejoras } \\
\text { efectuadas al marco tributario para combatir } \\
\text { de mejor manera la elusión y evasión } \\
\text { tributaria, así como la informalidad. Este nivel } \\
\text { parte del país con menor desempeño de la } \\
\text { muestra tomada para el óptimo de zona euro } \\
\text { OCDE 2010-2012 (España). }\end{array}$ \\
\hline & $\begin{array}{l}\text { Ingresos no } \\
\text { tributarios GC } \\
\quad \text { / PIB }\end{array}$ & 4 & $\begin{array}{l}\text { En un escenario con mejor manejo de los } \\
\text { recursos públicos de la masa crítica de } \\
\text { contribuciones sociales, contribuyen a que } \\
\text { los ingresos no tributarios alcancen un 8,6\% } \\
\text { del PIB, tomando como referencia el nivel } \\
\text { observado al país con menor desempeño de la } \\
\text { muestra tomada para el óptimo de la zona euro } \\
\text { OCDE 2010-2012 (Dinamarca). }\end{array}$ \\
\hline Ahorro público & $\begin{array}{l}\text { Activos } \\
\text { financieros / } \\
\text { Gastos del GC }\end{array}$ & 9 & $\begin{array}{l}\text { El Tesoro rentabiliza sus fondos en distintas } \\
\text { alternativas de inversión, como parte de la } \\
\text { gestión de sus activos y pasivos, alcanzándose } \\
\text { un indicador cercano a 87,7\%, promedio del de } \\
\text { Chile en 2006-2013. }\end{array}$ \\
\hline \multirow[b]{2}{*}{$\begin{array}{l}\text { Desarrollo } \\
\text { de mercados } \\
\text { financieros }\end{array}$} & $\begin{array}{l}\text { Saldo de bonos } \\
\text { públicos y } \\
\text { privados en } \\
\text { moneda local } \\
\text { / PIB }\end{array}$ & 7 & $\begin{array}{l}\text { Se alcanza un nivel de } 35 \% \text { luego que las } \\
\text { acciones tomadas se concretan en un mercado } \\
\text { de deuda pública y privada en moneda local } \\
\text { más desarrollo y dinámico, siendo el menor } \\
\text { desempeño de la muestra utilizada para el } \\
\text { indicador óptimo (Chile 2005). }\end{array}$ \\
\hline & $\begin{array}{l}\text { Diferencial de } \\
\text { tasas activas y } \\
\text { pasivas } \%\end{array}$ & 9 & $\begin{array}{l}\text { Tomadas una serie de medidas que impulsaron } \\
\text { la mayor competencia y desarrollo de los } \\
\text { mercados financieros, incluido el ingreso } \\
\text { de nuevas entidades bancarias, mayor } \\
\text { supervisión con nuevos estándares, entre } \\
\text { otros, el indicador alcanza un 5\%, tomando } \\
\text { como referencia el país con menor desempeño } \\
\text { de la muestra tomada para el óptimo AAA- } \\
\text { OCDE } 2005-2014 \text {. En 2014, Brasil, México y } \\
\text { Colombia registraron un diferencial de } 10 \% \text { en } \\
\text { promedio y Chile un diferencial de } 4 \% \text {. }\end{array}$ \\
\hline $\begin{array}{l}\text { Estabilidad } \\
\text { financiera }\end{array}$ & $\begin{array}{l}\text { Desviación } \\
\text { estándar de } \\
\text { rendimiento a } 10 \\
\text { años del Tesoro }\end{array}$ & 8 & $\begin{array}{l}\text { La volatilidad del rendimiento de los bonos } \\
\text { llega a } 34 \text { pb por el incremento de la base de } \\
\text { inversionistas locales, dándole más liquidez } \\
\text { y menor volatilidad a la curva. Este indicador } \\
\text { toma como referencia el promedio de los bonos } \\
\text { del Tesoro de EEUU en 2000-2013. }\end{array}$ \\
\hline $\begin{array}{l}\text { Dolarización } \\
\text { financiera }\end{array}$ & $\begin{array}{l}\text { Depósitos } \\
\text { en dólares / } \\
\text { Depósitos en } \\
\text { total }\end{array}$ & 9 & $\begin{array}{l}\text { Indicador alcanza el } 13,4 \% \text {, tomando como } \\
\text { referencia el promedio OCDE, acercándose al } \\
6,5 \% \text { mostrado por Nueva Zelanda al } 2014 \text {. }\end{array}$ \\
\hline
\end{tabular}

Fuente: MEF (2015a). Elaboración: Propia 
Cuadro 12.

Riesgos y oportunidades en el escenario A

\begin{tabular}{|c|c|}
\hline Riesgos & Oportunidades \\
\hline \multicolumn{2}{|c|}{ Producto interno bruto } \\
\hline $\begin{array}{l}\text { Incumplimiento de estándares de producción } \\
\text { acordes a OCDE. } \\
\square \text { Dificultad para alcanzar mayores ganancias } \\
\text { de competitividad de la producción de bienes } \\
\text { primarios. } \\
\text { Inequidad en la distribución de la riqueza con } \\
\text { salarios desvinculados de la productividad } \\
\text { laboral que afectan el clima social. } \\
\square \text { Reducción de la fuerza laboral. }\end{array}$ & $\begin{array}{l}\text { Menor probabilidad de contagio ante crisis } \\
\text { sistémicas. } \\
\text { Mayor comercio internacional y más socios } \\
\text { comerciales. } \\
\square \text { Planes de contingencia institucionalizados } \\
\text { para crisis diversas. } \\
\text { Mayor competitividad de producción de } \\
\text { bienes finales. } \\
\text { Desconcentración de la producción a lo largo } \\
\text { y ancho del país, con un crecimiento más } \\
\text { ordenado de la economía. }\end{array}$ \\
\hline \multicolumn{2}{|c|}{ Institucionalidad } \\
\hline $\begin{array}{l}\square \text { Dificultad en la implementación de } \\
\text { regulaciones más avanzadas. } \\
\text { Inestabilidad social y política de sectores } \\
\text { reacios a las reformas. } \\
\text { Surgimiento de partidos políticos de } \\
\text { oposición que dificulten la aprobación de } \\
\text { medidas complementarias de mejora. } \\
\text { Mayor nivel de ahorros públicos genera } \\
\text { incentivos perversos para actos de } \\
\text { corrupción. } \\
\square \text { Educación superior no se adecua a las nuevas } \\
\text { necesidades. }\end{array}$ & $\begin{array}{l}\text { Homologación con estándares } \\
\text { internacionales más avanzados e } \\
\text { implementación de nuevos estándares contra } \\
\text { la corrupción. } \\
\square \text { Eliminación de asimetrías regulatorias que } \\
\text { inhiben competencia. } \\
\square \text { Institucionalización de la gestión de activos y } \\
\text { pasivos financieros y no financieros en todos } \\
\text { los niveles de Gobierno. } \\
\square \text { Segregación del Sector Economía del Sector } \\
\text { Finanzas. } \\
\text { Programas de capacitación para homologar al } \\
\text { nivel de OCDE. }\end{array}$ \\
\hline \multicolumn{2}{|c|}{ Deuda pública } \\
\hline $\begin{array}{l}\text { Mayor capacidad para aplicar política fiscal } \\
\text { expansiva incrementa más rápidamente el } \\
\text { endeudamiento si no suben los ingresos. } \\
\text { Mayor deuda externa para satisfacer mayor } \\
\text { demanda por tener una mejor calificación } \\
\text { soberana. } \\
\text { Mercado de valores en soles es utilizado } \\
\text { por extranjeros para cubrirse de mercados } \\
\text { emergentes menos líquidos. } \\
\text { Embelesamiento por menor costo de títulos } \\
\text { de corto plazo. }\end{array}$ & $\begin{array}{l}\square \text { Desarrollo del mercado de derivados de los } \\
\text { títulos del Tesoro. } \\
\square \text { Integración de los mercados de valores de } \\
\text { deuda pública en moneda local entre países } \\
\text { de la Alianza del Pacífico. } \\
\text { Captación de fondos a menor costo por } \\
\text { menor riesgo soberano. } \\
\text { Menor costo de financiamiento dinamiza la } \\
\text { inclusión financiera. } \\
\square \text { Entidades microfinancieras facilitan la } \\
\text { descentralización del ahorro y el crédito en } \\
\text { todo el territorio nacional. }\end{array}$ \\
\hline
\end{tabular}


Pensamiento Crítico Vol. 22. $\mathrm{N}^{\circ} 2$

\begin{tabular}{|c|c|}
\hline Riesgos & Oportunidades \\
\hline \multicolumn{2}{|c|}{ Ingreso público } \\
\hline $\begin{array}{l}\text { Ampliación de la base tributaria genera } \\
\text { nuevos retos más sofisticados para la } \\
\text { supervisión. } \\
\text { Escasez de personal calificado para la } \\
\text { implementación de nuevas reformas y } \\
\text { modernización de los sistemas tributarios. } \\
\text { Persistencia de altos niveles de informalidad } \\
\text { por tratarse de un aspecto cultural resistente } \\
\text { al cambio. }\end{array}$ & $\begin{array}{l}\text { Nuevas políticas para ampliar la base } \\
\text { tributaria. } \\
\text { Fortalecimiento de las reservas de liquidez } \\
\text { con los recursos excedentes provenientes de } \\
\text { los sectores más dinámicos. } \\
\square \text { Mayor innovación y eficacia en materia de } \\
\text { recaudación. } \\
\square \text { Empoderamiento del Tesoro como líder del } \\
\text { proceso de ingresos, egresos y manejo de } \\
\text { activos y pasivos. }\end{array}$ \\
\hline \multicolumn{2}{|c|}{ Ahorro público } \\
\hline $\begin{array}{l}\text { Acumulación de activos financieros genera } \\
\text { descontento en sectores de más altas rentas } \\
\text { afectados por las reformas. } \\
\text { Incremento inesperado de los ahorros puede } \\
\text { genera una ineficiente gestión de fondos por } \\
\text { menores niveles de rentabilidad. } \\
\text { Acumulación de activos financieros genera } \\
\text { descontento en sectores no atendidos por } \\
\text { Gobierno. } \\
\text { Incapacidad de satisfacer demanda por } \\
\text { bonos del Tesoro por menor necesidad de } \\
\text { financiamiento. }\end{array}$ & $\begin{array}{l}\text { Creación de fondos alternativos a los } \\
\text { destinados a contingencias ante situaciones } \\
\text { de iliquidez que garanticen una mayor } \\
\text { estabilidad a las finanzas públicas (fondos } \\
\text { soberanos). } \\
\text { Mejor distribución intertemporal de los } \\
\text { recursos públicos. } \\
\text { Mayores mecanismos de transparencia y } \\
\text { control de fondos. } \\
\text { Constitución de índices soberanos de } \\
\text { referencia. } \\
\text { Adaptación de la reserva secundaria de } \\
\text { liquidez a cambios en las regulaciones y } \\
\text { nuevos escenarios estrés. }\end{array}$ \\
\hline \multicolumn{2}{|c|}{ Desarrollo de los mercados financieros } \\
\hline $\begin{array}{l}\text { Incremento abrupto en el nivel de } \\
\text { endeudamiento. } \\
\text { Concentración de deuda en el muy corto } \\
\text { plazo con extranjeros. } \\
\text { Menor diferencial de tasas de interés a } \\
\text { entidades más pequeñas. } \\
\text { Mayor oferta de fondos genera burbuja } \\
\text { crediticia. } \\
\text { Mercado de valores de deuda pública reduce } \\
\text { su importancia. }\end{array}$ & $\begin{array}{l}\square \text { Mayor desdolarización de la deuda pública y } \\
\text { privada. } \\
\square \text { Mayor capacidad para hacer frente a } \\
\text { depreciaciones cambiarias. } \\
\square \text { Menores primas de emisión de deuda } \\
\text { privada. } \\
\square \text { Menor riesgo de financiamiento de } \\
\text { concesiones. } \\
\square \text { Implementación de nuevas regulaciones } \\
\text { impuesta por Basilea. }\end{array}$ \\
\hline
\end{tabular}




\begin{tabular}{|c|c|}
\hline Riesgos & Oportunidades \\
\hline \multicolumn{2}{|c|}{ Estabilidad financiera } \\
\hline $\begin{array}{l}\text { Mayor apertura de los mercados financieros } \\
\text { incrementa la posibilidad de contagio de } \\
\text { exacerbación de la volatilidad internacional. } \\
\text { Mayor movilidad de capitales externos de } \\
\text { corto plazo afectan la política monetaria. } \\
\text { Mayor apertura facilita abrupta salida de sus } \\
\text { capitales. } \\
\text { Inversionistas buscan mercados con más } \\
\text { volatilidad para generar ganancias mayores } \\
\text { en el corto plazo. }\end{array}$ & $\begin{array}{l}\text { Incremento de fondos facilitan el } \\
\text { financiamiento de infraestructura. } \\
\text { Fortalecimiento de entidades financieras } \\
\text { locales. } \\
\text { Promoción de fondos cotizados (ETF) con } \\
\text { deuda pública local. } \\
\text { Mayor margen de maniobra para otorgar } \\
\text { primas a los inversionistas locales en las } \\
\text { emisiones primarias. } \\
\text { Intervención del Tesoro en el mercado de } \\
\text { valores de deuda pública permite moderar } \\
\text { situaciones de inestabilidad. }\end{array}$ \\
\hline \multicolumn{2}{|c|}{ Dolarización financiera } \\
\hline $\begin{array}{l}\text { Instrumentos en moneda local resultan } \\
\text { insuficientes para cubrir demanda local e } \\
\text { internacional. } \\
\text { Dolarización de los pasivos bancarios mayor } \\
\text { a la dolarización de los activos bancarios. }\end{array}$ & $\begin{array}{l}\text { Impulso de educación financiera a través de } \\
\text { un portal del Tesoro. } \\
\square \text { Instrumentos locales acordes al perfil de cada } \\
\text { tipo de inversionista. } \\
\square \text { Moneda local genera confianza en su } \\
\text { intercambio en otros países. } \\
\square \text { Deja de tener representatividad la curva de } \\
\text { deuda en dólares local. }\end{array}$ \\
\hline
\end{tabular}

Fuente: MEF (2015a). Elaboración: Propia

En este escenario del ejercicio, la capacidad de generar ingresos públicos es mayor, lo que se traduce en una mayor capacidad de pago reflejada en un indicador de deuda respecto de los ingresos públicos del $82 \%$. Asimismo, los estudios e intercambio de experiencias con la OCDE permiten mejoras en áreas tan diversas como la economía, el comercio, las inversiones, el desarrollo social, la educación (fundamental), el desarrollo territorial, el medioambiente, la administración pública, la agricultura, el empleo y las políticas de ciencia y tecnología, entre otras. Este intercambio permite seguir mejorando los indicadores más relevantes para el mayor bienestar social y en línea con la que tienen países con una calificación de riesgo soberano de entre $\mathrm{A}+\mathrm{y} \mathrm{AA}-(\mathrm{Cuadro} 11)$. Por tanto, en este escenario exploratorio positivo, la mayoría de las variables estratégicas muestran un mejor desempeño en relación al escenario base. Resaltan mejoras importantes en algunas variables como el grado de institucionalidad que está ligada a cambios estructurales de largo plazo. 
Asimismo, los indicadores de deuda pública muestran un desempeño cercano a los niveles óptimos, así, el mercado de bonos soberanos crece significativamente, con la ejecución económicamente más eficiente de operaciones en el mercado doméstico. La mejor lectura de precios de los instrumentos públicos se traslada a los precios de los instrumentos privados. Los mercados financieros muestran una dinámica positiva traducida en un mercado más grande y con menor costo financiero. Este comportamiento está correlacionado con un mejor desempeño del sector real de la economía. Los pilares que sustentan esta mejora son: i) una mayor diversificación de las exportaciones por lo cual los efectos de una reducción de precios de materias primas se disipan, ii) las mejores políticas de recaudación tributarias que permiten un incremento de los ingresos públicos, y iii) la inversión privada y pública permiten un mayor desarrollo de infraestructura para el país. Por el lado del ahorro público, se muestra un resultado favorable, en medio de una mayor acumulación de activos financieros producto de la mayor recaudación y mejores resultados fiscales, así como por una administración de caja más activa en beneficio de la República. Este efecto es mucho mayor que los egresos que pueda generar el gobierno en este escenario producto de un mayor gasto en consumo e inversión.

\section{Escenario exploratorio B (Precios de materias primas caen $50 \%)$}

Para este paso, en el ejercicio se supone que se produce un fuerte agravamiento de la tendencia que se viene configurando desde los primeros meses del año 2011 y que, de acuerdo a las estimaciones del FMI (2015), se espera que dicha tendencia continúe en los próximos años. Los precios de las materias primas aumentaron durante el período de moderación en los países de la OCDE y durante los años de bonanza económica de China (2003-2008), donde los productos primarios se volvieron cada vez más importantes para Latinoamérica respecto a las exportaciones, los ingresos fiscales y el empleo (Gráfico 5). En ese sentido, el impacto de la fuerte caída de los precios de las materias primas en el Perú (primario exportador de minerales) tiene consecuencias significativas para su posición fiscal y su posición externa. Por un lado, los ingresos por exportaciones de minerales experimentan una caída importante y persistente afectando los ingresos fiscales, lo cual requiere de la adopción de algunas medidas adicionales 
para reducir el déficit. En tanto que respecto a la posición externa, el estudio del FMI indica que la evidencia histórica muestra que el deterioro de la balanza comercial será relativamente moderado y de corta duración.

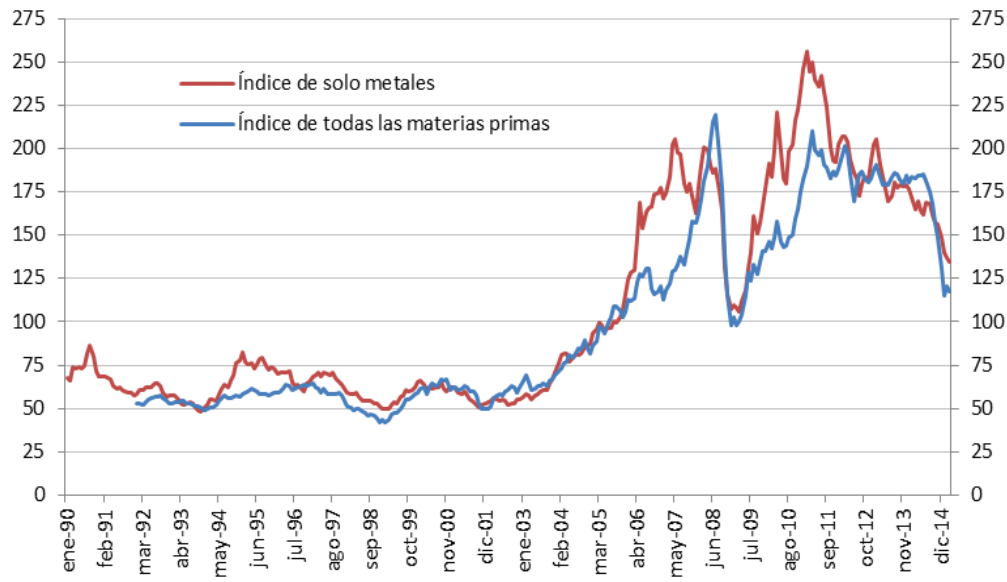

Gráfico 5. Evolución de los precios internacionales de las materias primas Nota: Índice de solo metales incluye precios de cobre, aluminio, oro, zinc, plata, etc. $(2005=100)$.

Fuentes: FMI Elaboración: Propia

En particular, el ajuste del sector externo no suele darse por un aumento de las exportaciones no relacionadas con las materias primas, sino más bien por una aguda compresión de las importaciones, especialmente en países que tienen regímenes cambiarios más rígidos y escasa diversificación de las exportaciones. Algunos analistas atribuyen como causa de la disminución de los precios de las materias primas al menor crecimiento económico de China y a las expectativas de necesidad de cambio de su modelo. Por ello, en este escenario se concibe un crecimiento chino de $4 \%$ anual, tomando en cuenta la menor demanda de sus productos y servicios y el excesivo nivel del crédito $(200 \%$ del PIB) y el elevado nivel de la inversión (47\% del PIB), en un contexto de rendimientos decrecientes en la economía china (Hoffman y Polk 2014).

Para este escenario, se considera la media de los indicadores estratégicos durante el periodo 2002-2008, ya que en este periodo se observó un indicador promedio del índice de minerales de 111 (2005=100), mientras que del año 2009 (post crisis) al año 2014 se apreció un índice de precios de minerales promedio de 187 (Cuadro 13). Ante ello, en este 
escenario exploratorio se concibe un futuro donde se vuelve a los precios promedio del periodo 2002-2008, con lo cual, se tendría un retroceso de más de 50\% del índice de precios de los minerales (Gráfico 5). Por ello, la mayoría de variables estratégicas muestran un desempeño desfavorable. El PIB per cápita real se mantiene estancado por el menor valor de las exportaciones tradicionales y menor inversión privada. Se observa un fuerte impacto en la recaudación fiscaly, por ende, en el resultado fiscal por los menores ingresos percibidos. Respecto de las variables estratégicas que miden el comportamiento de los pasivos financieros, se aprecia que el indicador de deuda externa sobre deuda total resulta desfavorable respecto al escenario base ya que, ante la necesidad de financiar el resultado fiscal negativo por los menores ingresos tributarios, el Gobierno emite más deuda externa, con la probabilidad de pagar primas más altas y mayores costo por depreciación del tipo de cambio. En el mismo sentido, el indicador de deuda respecto a ingresos del gobierno denota un desempeño negativo afectado tanto por la mayor emisión de deuda, y de otro lado, por la disminución de los ingresos tributarios que afectan los ingresos totales del gobierno central. En tanto la variable ahorro público que es medida a través de la capacidad de los activos financieros existentes para cubrir parte de los egresos y pasivos contingencias del Gobierno Central, se encuentra por debajo del escenario base, complicándose aún más en este escenario ya que el Gobierno requerirá de una parte de sus activos financieros para financiar el resultado fiscal negativo (Cuadro 14).

\section{Cuadro 13.}

Construcción de escenario exploratorio $B$

\begin{tabular}{|c|c|c|l|}
\hline $\begin{array}{c}\text { Variable } \\
\text { estratégica }\end{array}$ & Indicador & Calificación & $\begin{array}{l}\text { Escenario precios de materias primas caen } \\
\mathbf{5 0 \%}\end{array}$ \\
\hline $\begin{array}{c}\text { Producto interno } \\
\text { bruto }\end{array}$ & PIB per cápita PPA & 4 & $\begin{array}{l}\text { Según la evidencia estadística del periodo } \\
1990-2014, \text { se aprecia una relación directa } \\
\text { entre el índice de precios de minerales y el } \\
\text { PIB per cápita (correlación 87\%). Por ello, se } \\
\text { espera un efecto significativamente adverso } \\
\text { en el PIB per cápita, aunque esta relación en } \\
\text { los últimos años parece más moderada en } \\
\text { un contexto en el que se está impulsando } \\
\text { la exportación de bienes no tradicionales, } \\
\text { aunque su participación aún es baja. En ese } \\
\text { contexto, se espera que el PIB PPA registre } \\
\text { US\$14 747. }\end{array}$ \\
\hline
\end{tabular}


RENZO A. JIMÉnEZ SoTELo

\begin{tabular}{|c|c|c|c|}
\hline $\begin{array}{l}\text { Variable } \\
\text { estratégica }\end{array}$ & Indicador & Calificación & $\begin{array}{l}\text { Escenario precios de materias primas caen } \\
\mathbf{5 0 \%}\end{array}$ \\
\hline Institucionalidad & $\begin{array}{c}\text { Nivel de } \\
\text { institucionalidad }\end{array}$ & 2 & $\begin{array}{l}\text { Ante los menores ingresos percibidos en este } \\
\text { escenario, se espera un nivel similar al actual } \\
\text { cercano a 3,33 en el año } 2030 \text {. }\end{array}$ \\
\hline \multirow{3}{*}{ Deuda pública } & $\begin{array}{l}\text { Deuda / Ingresos } \\
\text { GC }\end{array}$ & 3 & $\begin{array}{l}\text { Este indicador muestra un desempeño } \\
\text { desfavorable ya que caen los ingresos del } \\
\text { Gobierno Central, los que sólo en el corto } \\
\text { plazo caerían en } 4,2 \% \text { en términos reales } \\
\text { (MEF 2015). En el actual contexto, donde se } \\
\text { están proyectando la ejecución de proyectos } \\
\text { de gran envergadura que significarán mayor } \\
\text { endeudamiento, con lo cual el indicador } \\
\text { alcanza el 208,8\%, cerca al promedio obtenido } \\
\text { por países BB entre } 2005 \text { y } 2014 \text {. }\end{array}$ \\
\hline & $\begin{array}{l}\text { Deuda externa / } \\
\text { Total deuda del GC }\end{array}$ & 2 & $\begin{array}{l}\text { El peso de la deuda externa pública respecto a } \\
\text { la deuda total pública se incrementa a } 82,4 \% \text {, } \\
\text { pues, el Gobierno recurre a deuda con los } \\
\text { organismos financieros internacionales para } \\
\text { financiar su déficit. }\end{array}$ \\
\hline & $\begin{array}{l}\text { Pago de intereses / } \\
\text { Ingresos GC }\end{array}$ & 1 & $\begin{array}{l}\text { Un mayor endeudamiento origina un mayor } \\
\text { pago de intereses que llegan a representar } \\
\text { un 10,1\%, sin incluir gastos por depreciación } \\
\text { del sol. }\end{array}$ \\
\hline \multirow[t]{2}{*}{ Ingresos públicos } & $\begin{array}{c}\text { Ingresos } \\
\text { tributarios GC / PIB }\end{array}$ & 2 & $\begin{array}{l}\text { Los ingresos tributarios del gobierno central } \\
\text { caen a 14,7\% del PIB, por la disminución } \\
\text { significativa de los ingresos provenientes } \\
\text { del impuesto a la renta de las empresas } \\
\text { mineras, así como por efecto de la menor } \\
\text { actividad económica. Cabe recordar que el } \\
\text { notable incremento de la renta económica de } \\
\text { la actividad minera a mediados de la década } \\
\text { de } 2000 \text { tuvo como correlato un significativo } \\
\text { aumento, en términos absolutos, de los } \\
\text { ingresos fiscales. En el Perú, los ingresos } \\
\text { provenientes de esta fuente entre } 2000 \text { y } 2007 \\
\text { pasaron de un escaso } 0,1 \% \text { del PIB en el } 2000 \\
\text { hasta alcanzar un máximo de } 2,9 \% \text { en el año } \\
2007 \text { (CEPAL 2015). }\end{array}$ \\
\hline & $\begin{array}{c}\text { Ingresos no } \\
\text { tributarios GC / PIB }\end{array}$ & 1 & $\begin{array}{l}\text { Los ingresos no tributarios alcanzan un } \\
\text { indicador promedio de } 2,3 \% \text {. }\end{array}$ \\
\hline Ahorro público & $\begin{array}{l}\text { Activos financieros } \\
\text { / Gastos del GC }\end{array}$ & 3 & $\begin{array}{l}\text { El Gobierno utiliza una parte significativa de } \\
\text { sus excedentes, dada la menor recaudación } \\
\text { y el incremento de gastos financieros por el } \\
\text { mayor endeudamiento, además de la subida } \\
\text { del tipo de cambio y las tasas de interés, con lo } \\
\text { que se alcanza un } 27,3 \% \text {. }\end{array}$ \\
\hline
\end{tabular}


Pensamiento Crítico Vol. 22. N²

\begin{tabular}{|c|c|c|c|}
\hline $\begin{array}{l}\text { Variable } \\
\text { estratégica }\end{array}$ & Indicador & Calificación & $\begin{array}{l}\text { Escenario precios de materias primas caen } \\
\mathbf{5 0 \%}\end{array}$ \\
\hline \multirow[b]{2}{*}{$\begin{array}{l}\text { Desarrollo } \\
\text { de mercados } \\
\text { financieros }\end{array}$} & $\begin{array}{l}\text { Saldo de bonos } \\
\text { públicos y privados } \\
\text { en moneda local } \\
\text { / PIB }\end{array}$ & 1 & $\begin{array}{l}\text { El monto de bonos privados y públicos } \\
\text { emitidos en moneda local respecto al PIB } \\
\text { registra un nivel de } 5,6 \% \text {, el promedio que } \\
\text { se tenía en los años anteriores a la subida } \\
\text { del precio de las materias primas, pero } \\
\text { posteriores a la implementación de la meta de } \\
\text { inflación. }\end{array}$ \\
\hline & $\begin{array}{l}\text { Diferencial de tasas } \\
\text { activas y pasivas } \%\end{array}$ & 3 & $\begin{array}{l}\text { La menor actividad económica y el incremento } \\
\text { de la morosidad crediticia, sobre todo de los } \\
\text { créditos en dólares que ven afectados por la } \\
\text { depreciación de la moneda local aumentan } \\
\text { el diferencial de tasas de interés. El caída de } \\
\text { las tasas de crecimiento entre los años } 1997 \\
\text { y } 1999 \text {, registró un valor negativo en el año } \\
1999 \text { y tuvo relación con un incremento de } \\
\text { casi +300 pb del diferencial de tasas de interés } \\
\text { en moneda nacional. Este comportamiento } \\
\text { eleva el costo de las entidades financieras que, } \\
\text { para recuperar sus ganancias, incrementan } \\
\text { sus tasas activas, con lo cual el diferencial } \\
\text { alcanza un } 19 \% \text {. En Chile, cuando su } \\
\text { crecimiento pasó de }+5,1 \% \text { a }-1,03 \% \text { entre } \\
2007 \text { y } 2009 \text { se observó un incremento del } \\
\text { diferencial de }+214 \text { pb. En México se apreció } \\
\text { un incremento de }+70 \text { pb, cuando el PIB pasó } \\
\text { de }+3,14 \% \text { a }-4,7 \% \text {. }\end{array}$ \\
\hline $\begin{array}{l}\text { Estabilidad } \\
\text { financiera }\end{array}$ & $\begin{array}{l}\text { Desviación } \\
\text { estándar de } \\
\text { rendimiento a } 10 \\
\text { años del Tesoro }\end{array}$ & 4 & $\begin{array}{l}\text { Una caída del precio de las materias primas } \\
\text { incide negativamente sobre la volatilidad, } \\
\text { cuyo efecto es mayor si se considera una } \\
\text { depreciación de la moneda local, elevando la } \\
\text { volatilidad a + } 64 \text { pb. }\end{array}$ \\
\hline $\begin{array}{l}\text { Dolarización } \\
\text { financiera }\end{array}$ & $\begin{array}{l}\text { Depósitos en } \\
\text { dólares / Depósitos } \\
\text { totales }\end{array}$ & 2 & $\begin{array}{l}\text { En este escenario alcanza un } 65,1 \% \text {, en un } \\
\text { contexto donde la depreciación de la moneda } \\
\text { local impulsa la demanda por dólares. }\end{array}$ \\
\hline
\end{tabular}

Fuente: MEF (2015a). Elaboración: Propia 


\section{Cuadro 14.}

Riesgos y oportunidades en el escenario exploratorio $B$

\begin{tabular}{|c|c|}
\hline Riesgos & Oportunidades \\
\hline \multicolumn{2}{|c|}{ Producto interno bruto } \\
\hline $\begin{array}{l}\square \text { Aplazamiento en la ejecución de proyectos } \\
\text { públicos y privados relacionados a la } \\
\text { actividad extractiva no iniciados. } \\
\square \text { Disminución de la inversión reduce el } \\
\text { crecimiento potencial. } \\
\square \text { Menor capacidad para financiar déficit en } \\
\text { cuenta corriente. } \\
\square \text { Deterioro de capacidad del gasto público por } \\
\text { menores ingresos. }\end{array}$ & $\begin{array}{l}\text { Necesidad de implementar de políticas de } \\
\text { diversificación productiva y de incentivo de } \\
\text { exportaciones no tradicionales. } \\
\text { Necesidad de mejorar mecanismos para } \\
\text { asegurar mayor eficiencia del gasto público } \\
\text { presupuestario y extra presupuestaria }\end{array}$ \\
\hline \multicolumn{2}{|c|}{ Institucionalidad } \\
\hline $\begin{array}{l}\square \text { Menor presupuesto para la modernización } \\
\text { del Estado. } \\
\square \text { Disminución de ingresos fiscales obligan } \\
\text { al recorte de programas sociales, } \\
\text { incrementándose los conflictos sociales. } \\
\square \text { Legislación más laxa respecto a las } \\
\text { externalidades negativas ocasionadas por la } \\
\text { actividad extractiva. } \\
\square \text { Crecimiento de la informalidad por menor } \\
\text { crecimiento. }\end{array}$ & $\begin{array}{l}\text { Creación de mecanismos para mejorar la } \\
\text { eficiencia y calidad del gasto público y reducir } \\
\text { la corrupción. } \\
\text { Reducción o desaparición de las actividades } \\
\text { de minería informal y reducción de sus } \\
\text { externalidades negativas. } \\
\text { Desarrollo de políticas para cambiar el } \\
\text { modelo de desarrollo basado en actividades } \\
\text { extractivas. }\end{array}$ \\
\hline \multicolumn{2}{|c|}{ Deuda pública } \\
\hline $\begin{array}{l}\square \text { Incremento para cubrir gasto ante menores de } \\
\text { ingresos. } \\
\square \text { Contracción de la incipiente demanda local } \\
\text { por títulos del Tesoro obligando a aumentar la } \\
\text { deuda externa. } \\
\square \text { Emisiones de deuda externa exigen tasas } \\
\text { de interés y primas más por deterioro de } \\
\text { capacidad de pago. } \\
\square \text { Crecimiento de los ingresos a tasas menores } \\
\text { originan mayores gastos financieros } \\
\text { proporcionales en el presupuesto. }\end{array}$ & $\begin{array}{l}\text { Desarrollo del mercado doméstico de } \\
\text { deuda pública en soles para no empeorar } \\
\text { vulnerabilidad financiera externa. } \\
\text { Modernizar el mercado doméstico de deuda } \\
\text { pública para ampliar la base de inversionistas } \\
\text { locales y desdolarizar la deuda de organismos } \\
\text { multilaterales. }\end{array}$ \\
\hline \multicolumn{2}{|c|}{ Ingreso público } \\
\hline $\begin{array}{l}\square \text { Disminución de la calificación soberana } \\
\text { por menor capacidad de pago por menores } \\
\text { ingresos de exportaciones tradicionales. } \\
\square \text { Imposibilidad de visionar un mayor gasto en } \\
\text { rubros significativos para la ciudadanía como } \\
\text { más obras públicas. }\end{array}$ & $\begin{array}{l}\text { Necesidad de implementar reformas } \\
\text { tributarias que diversifiquen la base tributaria } \\
\text { y reduzcan la evasión y la elusión. } \\
\text { Mayor importancia de las reformas para } \\
\text { obtener mayores ingresos públicos en los } \\
\text { otros niveles de gobierno. }\end{array}$ \\
\hline
\end{tabular}


Pensamiento Crítico Vol. 22. $\mathrm{N}^{\circ} 2$

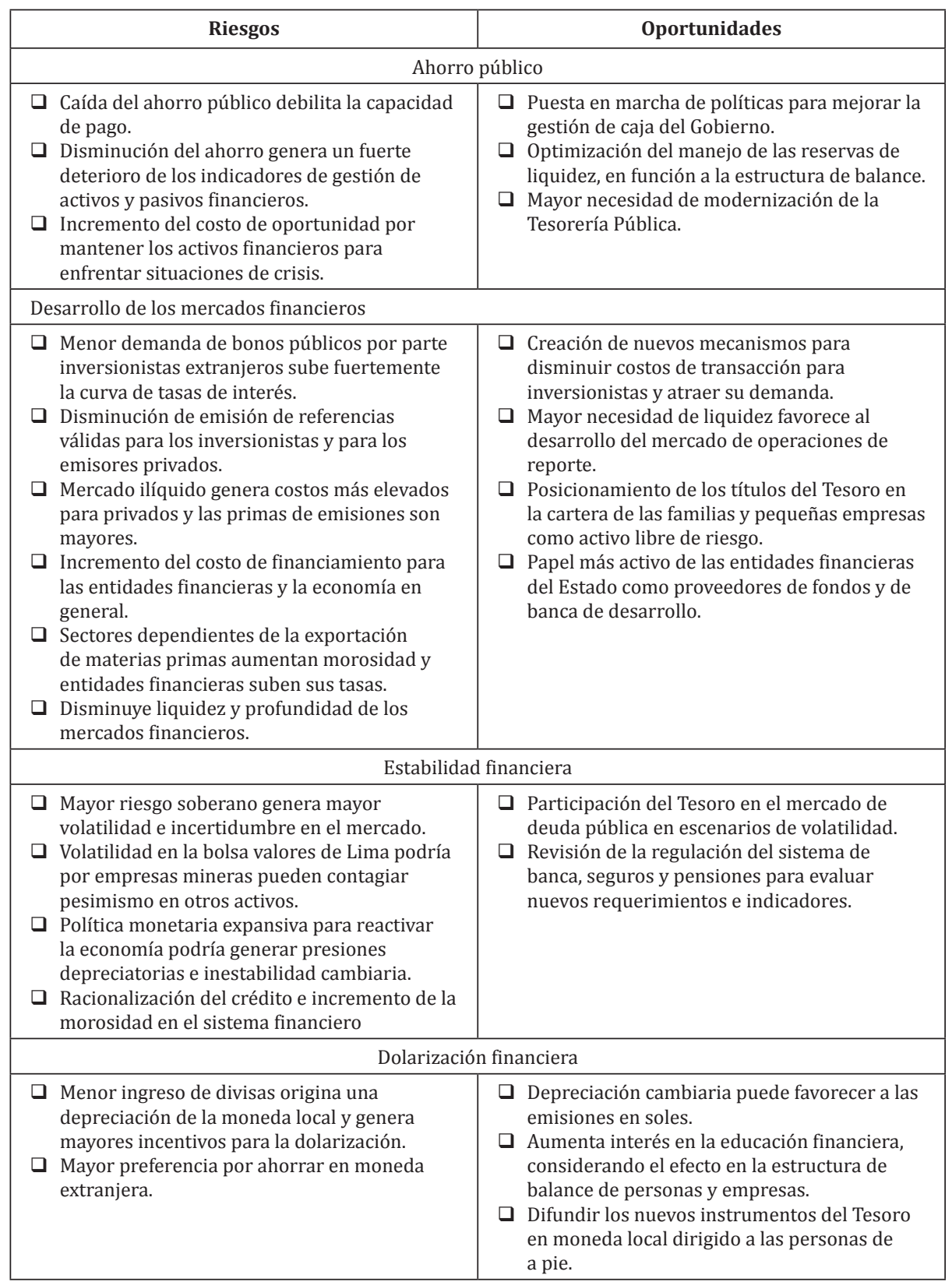

Fuente: MEF (2015a). Elaboración: Propia 


\section{Escenario exploratorio C: Tasa de referencia en EEUU sube a 5\%}

Para este paso, en el ejercicio se asumen los efectos de un fuerte incremento de la tasas de interés en Estados Unidos, lo que hace más atractivo volver a invertir en dicho país y en activos denominados en su divisa. En este escenario mejora mucho la evolución de la situación económica estadounidense observada en los últimos años, donde desde el año 2008 la tasa de referencia era de casi cero $(0,25 \%)$, reflejada en que la mejora de la actividad en ese país se concentran en los avances del mercado laboral, el sector inmobiliario e industrial, impulsado el consumo de hogares y empresas, desempeño que presiona sobre la inflación (Gráfico 6).

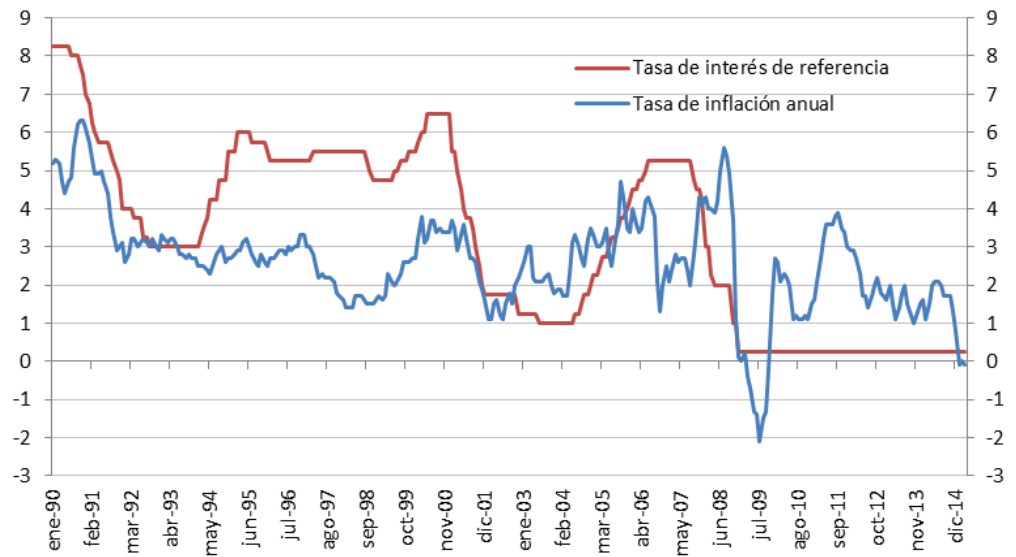

Gráfico 6. Evolución de tasa de inflación y tasa de referencia en los EEUU Fuentes: Bloomberg Elaboración: Propia

No obstante, ante ello, el Perú queda expuesto a una salida de capitales privados, lo que genera mayor dificultad para financiar el ya persistente déficit en cuenta corriente, lo que se agrava por la aún importante participación de inversionistas extranjeros en el mercado de valores local. Además, la menor disponibilidad de dólares dentro del país presiona a una mayor subida del tipo de cambio, con lo cual, además de la salida de capitales y mayores expectativas de depreciación, se genera un efecto negativo sobre los bienes importados, afectando la tasa de inflación. Por ello, el banco central se ve forzado a incrementar su tasa de referencia, tanto para mitigar la salida de capitales como para moderar la inflación, lo que tiene un efecto contractivo en la economía encareciendo el crédito con moneda local, además de hacer menos 
rentables el desarrollo de nuevos proyectos e inversiones. Dada la aún alta dolarización financiera, el encarecimiento del crédito en dólares medidos en soles hace que aumente la morosidad de créditos denominados en dicha moneda que tiene como sujetos de crédito a empresas y familias locales que generan sus ingresos en soles. Como la mitad de la deuda pública también está dolarizada, también se tiene un efecto adverso en la capacidad de pago del Gobierno. Asimismo, también quedan expuestas otras deficiencias como la vulnerabilidad de la actividad económica local a los posibles choques externos adversos, que repercuten directamente sobre el PIB, la recaudación y la inversión pública y privada, entre otros efectos desfavorables.

Al respecto, si bien el FMI (2015a) recomendó aplazar el alza de tasas del interés en EEUU hasta el 2016, frente al temor de los efectos negativos sobre el resto del mundo, especialmente los países emergentes, en el mercado ya se esperaba que el incremento de tasas de interés en EEUU empezara a fines de 2015 o a inicios de 2016, lo que complicaba el escenario también para otros países emergentes.

Para este escenario se consideró la media de los indicadores estratégicos ${ }^{5}$ del periodo 1994-2000 y 2006, tomando en cuenta que, en promedio, en estos periodos se observó una tasa de referencia de los Estados Unidos en torno a 5\%, permitiendo capturar una situación aproximado al escenario propuesto (Cuadro 15). La mayoría de variables estratégicas también muestran un desempeño desfavorable. El PIB per cápita real no sólo se mantiene estancado por la menor inversión privada y caída del consumo, sino que se reduce ligeramente. Los ingresos caen por la caída de la actividad económica, lo cual afecta directamente el resultado fiscal. Por el lado de los pasivos financieros, se aprecia que el indicador de deuda externa sobre deuda total resulta desfavorable respecto al escenario base, ya que en este escenario se espera que el incremento de tasas traiga un efecto mayor sobre la curva de rendimientos local que sobre la extranjera, pudiendo hacer menos caro el costo de endeudamiento en moneda extranjera. Además, el efecto de la depreciación de la moneda local desalienta a los inversionistas sobre papeles en esta denominación. Este efecto también se vería bajo un pago mayor de intereses. Respecto

${ }^{5}$ Para las variables deuda y ahorro público solo se tomó en cuenta la información del año 2002 en adelante. 


\section{a los activos financieros se espera una disminución para cubrir parte} de la caída de ingresos ante la disminución de la actividad económica, mostrando un ahorro público muy por debajo del escenario actual (Cuadro 16).

\section{Cuadro 15.}

Construcción de escenario exploratorio $C$

\begin{tabular}{|c|c|c|c|}
\hline $\begin{array}{c}\text { Variable } \\
\text { estratégica }\end{array}$ & Indicador & Calificación & $\begin{array}{l}\text { Escenario tasa de referencia en EEUU sube } \\
\text { a } 5 \%\end{array}$ \\
\hline $\begin{array}{l}\text { Producto interno } \\
\text { bruto }\end{array}$ & $\begin{array}{l}\text { PIB per cápita } \\
\text { PPA }\end{array}$ & 5 & $\begin{array}{l}\text { Con el incremento sostenido de las tasas de } \\
\text { interés en EEUU se espera que el rendimiento } \\
\text { relativo cambie a favor de los activos en dólares } \\
\text { por lo cual un primer efecto es una salida de } \\
\text { capitales privados, afectando la inversión y } \\
\text { el sector externo. Asimismo se espera una } \\
\text { depreciación de la moneda trasladándose } \\
\text { el efecto directamente sobre los bienes y } \\
\text { servicios del ciudadano de a pie. Por otro lado, } \\
\text { el BCRP se ve obligado a incrementar su tasa } \\
\text { de referencia, como en el periodo } 2003-2006 \text {. } \\
\text { En este nuevo escenario con tasas de interés } \\
\text { mayores se desalienta el consumo y algunas } \\
\text { inversiones dejan de ser rentables, afectando } \\
\text { la actividad económica. Por ello, se espera que } \\
\text { el PIB per cápita no avance y en promedio se } \\
\text { mantenga en la misma posición que la situación } \\
\text { por debajo de la tendencia con US\$ } 15420 \text {. }\end{array}$ \\
\hline Institucionalidad & $\begin{array}{c}\text { Nivel de } \\
\text { institucionalidad }\end{array}$ & 2 & $\begin{array}{l}\text { Con menores ingresos, el Gobierno no puede } \\
\text { priorizar la inversión para mejorar su } \\
\text { institucionalidad y el indicador sería de } 3.40 \text {. }\end{array}$ \\
\hline \multirow{3}{*}{ Deuda pública } & $\begin{array}{l}\text { Deuda / Ingresos } \\
\text { GC }\end{array}$ & 1 & $\begin{array}{l}\text { El indicador } 261 \% \text { muestra un desempeño } \\
\text { desfavorable con un mayor endeudamiento } \\
\text { para cubrir la caída de los ingresos y mayores } \\
\text { obligaciones contingentes y deuda en moneda } \\
\text { extranjera por depreciación. }\end{array}$ \\
\hline & $\begin{array}{l}\text { Deuda externa } \\
\text { / Total deuda } \\
\text { del GC }\end{array}$ & 2 & $\begin{array}{l}\text { La curva de rendimientos soberana del } \\
\text { Perú sufre un efecto mayor que la curva de } \\
\text { rendimientos de EEUU, lo que se agrava con } \\
\text { la depreciación de la moneda local. Si los } \\
\text { rendimientos de papeles locales son demasiado } \\
\text { altos, el costo de la nueva deuda externa con } \\
\text { multilaterales puede ser menor que endeudarse } \\
\text { en soles, aumentando la extranjerización de la } \\
\text { deuda. Así, el indicador alcanza un } 81,9 \% \text {. }\end{array}$ \\
\hline & $\begin{array}{l}\text { Pago de intereses } \\
\text { / Ingresos GC }\end{array}$ & 0 & $\begin{array}{l}\text { Mayor saldo de deuda en moneda extranjera } \\
\text { con un tipo de cambio alcista origina un mayor } \\
\text { pago de intereses que se agrava con una } \\
\text { disminución relativa de los ingresos y sube el } \\
\text { ratio a } 15,5 \% \text {. }\end{array}$ \\
\hline
\end{tabular}


Pensamiento Crítico Vol. 22. N$^{\circ}$

\begin{tabular}{|c|c|c|c|}
\hline $\begin{array}{c}\text { Variable } \\
\text { estratégica }\end{array}$ & Indicador & Calificación & $\begin{array}{l}\text { Escenario tasa de referencia en EEUU sube } \\
\text { a } 5 \%\end{array}$ \\
\hline \multirow[t]{2}{*}{ Ingresos públicos } & $\begin{array}{l}\text { Ingresos } \\
\text { tributarios GC } \\
\text { / PIB }\end{array}$ & 2 & $\begin{array}{l}\text { El efecto de unos mayores niveles de tasas } \\
\text { de interés afecta la inversión y el consumo, } \\
\text { provocando una disminución de los ingresos. } \\
\text { Por lo que se espera un indicador de } 14,2 \% \text { en } \\
\text { este escenario. }\end{array}$ \\
\hline & $\begin{array}{l}\text { Ingresos no } \\
\text { tributarios GC } \\
\quad / \text { PIB }\end{array}$ & 1 & $\begin{array}{l}\text { La menor actividad lleva a este indicador a un } \\
2,0 \% \text { del PIB. }\end{array}$ \\
\hline Ahorro público & $\begin{array}{l}\text { Activos } \\
\text { financieros / } \\
\text { Gastos del GC }\end{array}$ & 2 & $\begin{array}{l}\text { En este escenario se recurre a parte de los } \\
\text { activos financieros ahorrados para cubrir } \\
\text { un deterioro de los ingresos, además que } \\
\text { los gastos, vía un mayor pago de intereses y } \\
\text { depreciación serían mayores, con lo cual, se } \\
\text { espera un indicador de } 24,3 \%\end{array}$ \\
\hline \multirow[b]{2}{*}{$\begin{array}{l}\text { Desarrollo } \\
\text { de mercados } \\
\text { financieros }\end{array}$} & $\begin{array}{l}\text { Saldo de bonos } \\
\text { públicos y } \\
\text { privados en } \\
\text { moneda local } \\
\text { / PIB }\end{array}$ & 0 & $\begin{array}{l}\text { Con una menor preferencia por bonos públicos } \\
\text { por parte de los inversionistas locales y } \\
\text { extranjeros, además de menores emisiones } \\
\text { de privados por el encarecimiento del } \\
\text { financiamiento en moneda local, el saldo de } \\
\text { bonos privados y públicos caería a 2,0\%. }\end{array}$ \\
\hline & $\begin{array}{l}\text { Diferencial de } \\
\text { tasas activas y } \\
\text { pasivas } \%\end{array}$ & 3 & $\begin{array}{l}\text { El efecto de una subida de tasas de interés tiene } \\
\text { más impacto sobre las tasas activas que sobre } \\
\text { las tasas pasivas. Además, una aceleración de } \\
\text { la depreciación de la moneda nacional tiende a } \\
\text { perjudicar la calidad crediticia de los hogares } \\
\text { y empresas que tienen créditos en moneda } \\
\text { extranjera, por lo que las entidades financieras } \\
\text { incrementan sus tasas activas para cubrir } \\
\text { parte de las pérdidas por mayor morosidad } \\
\text { (Jiménez 2010). Así, se espera un diferencial } \\
\text { de } 19,5 \%\end{array}$ \\
\hline $\begin{array}{l}\text { Estabilidad } \\
\text { financiera }\end{array}$ & $\begin{array}{l}\text { Desviación } \\
\text { estándar de } \\
\text { rendimiento a } 10 \\
\text { años del Tesoro }\end{array}$ & 5 & $\begin{array}{l}\text { La volatilidad se incrementa a } 58 \text { pb por la } \\
\text { incertidumbre que genera el aumento de la } \\
\text { tasa de interés de EE.UU en los mercados } \\
\text { internacionales. }\end{array}$ \\
\hline $\begin{array}{l}\text { Dolarización } \\
\text { financiera }\end{array}$ & $\begin{array}{l}\text { Depósitos } \\
\text { bancarios } \\
\text { en dólares } \\
\text { / Depósitos } \\
\text { bancarios totales }\end{array}$ & 2 & $\begin{array}{l}\text { Un tipo de cambio alcista origina una mayor } \\
\text { demanda por la moneda estadounidense, } \\
\text { como refugio frente a la pérdida de valor de la } \\
\text { moneda local. Así, se espera que el ratio suba } \\
\text { a } 71,9 \% \text {. }\end{array}$ \\
\hline
\end{tabular}

Fuente: MEF (2015a). Elaboración: Propia 
Cuadro 16.

Riesgos y oportunidades en el escenario de estrés

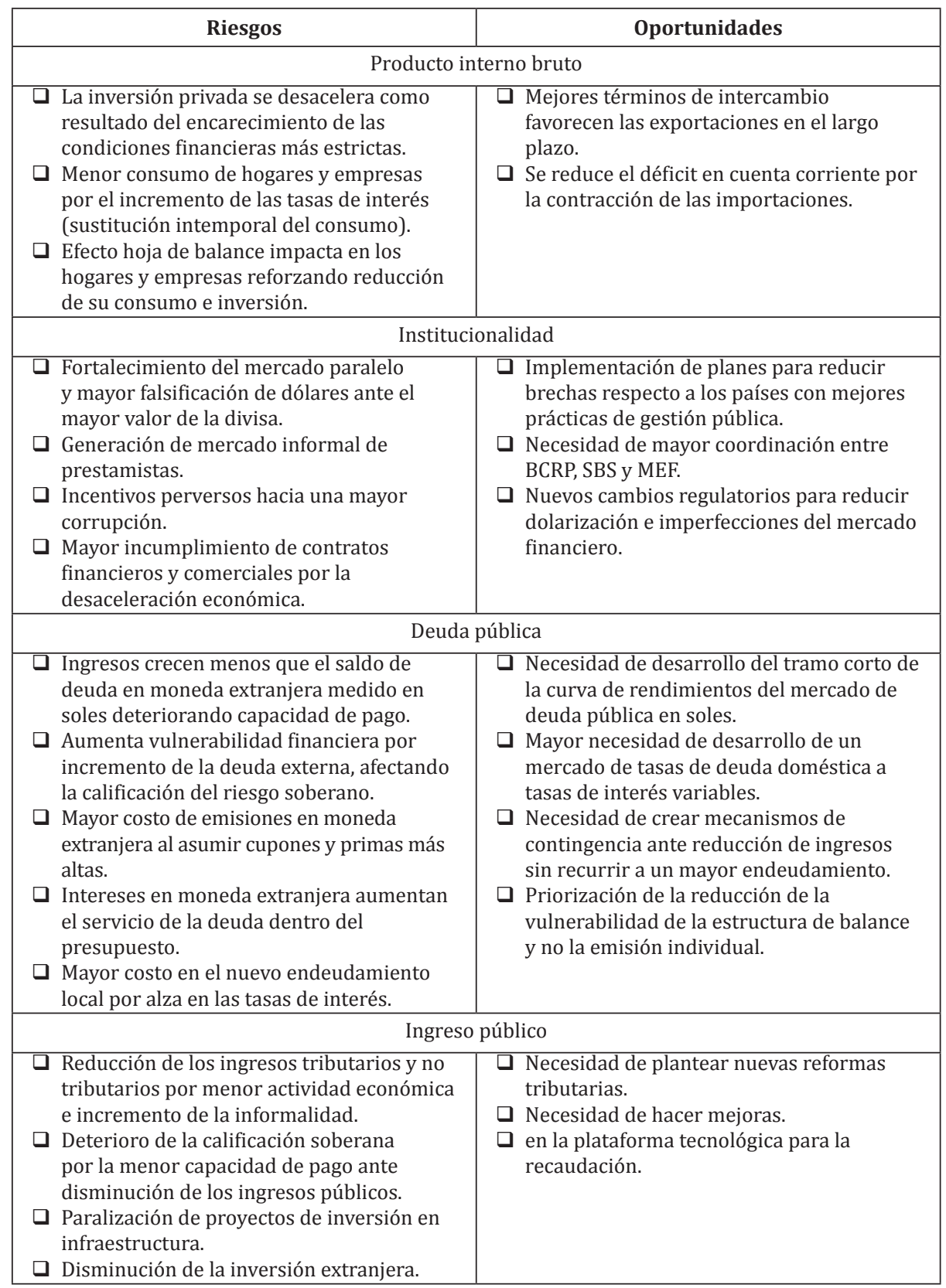


Pensamiento Crítico Vol. 22. $\mathrm{N}^{\circ} 2$

\begin{tabular}{|c|c|}
\hline Riesgos & Oportunidades \\
\hline \multicolumn{2}{|c|}{ Ahorro público } \\
\hline $\begin{array}{l}\text { Menor ahorro por el mayor gasto } \\
\text { público generado para hacer frente a una } \\
\text { desaceleración económica. } \\
\text { Una caída del ahorro público debilita la } \\
\text { capacidad de pago de la deuda bruta, } \\
\text { especialmente aquella denominada en } \\
\text { dólares. }\end{array}$ & $\begin{array}{l}\text { Necesidad de mejores políticas en la } \\
\text { gestión de caja. } \\
\text { Necesidad de hacer más eficiente la gestión } \\
\text { de las reservas de liquidez en función a la } \\
\text { estructura de balance. } \\
\text { Mayores ingresos generados por las } \\
\text { subastas de fondos del Tesoro. }\end{array}$ \\
\hline \multicolumn{2}{|c|}{ Desarrollo de los mercados financieros } \\
\hline $\begin{array}{l}\text { Menor desarrollo del mercado de deuda en } \\
\text { soles debido a la mayor incertidumbre y } \\
\text { riesgo de financiamiento. } \\
\square \text { Pérdida de referencias para las emisiones } \\
\text { de deuda privada. } \\
\square \text { Incertidumbre de acreedores sobre } \\
\text { capacidad de pago de sus deudores } \\
\text { incrementa diferencial de tasas de interés. } \\
\text { Menor liquidez en el mercado de capitales } \\
\text { incrementaría el diferencial de tasas de } \\
\text { interés. }\end{array}$ & $\begin{array}{l}\text { Mayor margen de maniobra para reformar } \\
\text { y modernizar el mercado de capitales. } \\
\text { Papel más activo para las entidades } \\
\text { financieras del Estado. } \\
\text { Desarrollo del mercado de deuda tiene un } \\
\text { efecto indirecto sobre las tasas activas vía } \\
\text { una mayor liquidez de los instrumentos de } \\
\text { deuda como las letras y bonos del Tesoro. }\end{array}$ \\
\hline \multicolumn{2}{|c|}{ Estabilidad financiera } \\
\hline $\begin{array}{l}\text { Se exacerba correlación de la curva de los } \\
\text { bonos de EEUU con la curva local en soles. } \\
\text { Exigencia de no residentes de mayores } \\
\text { primas en las emisiones de títulos del } \\
\text { Tesoro por depreciación esperada. } \\
\text { Deterioro de las expectativas de los } \\
\text { inversionistas adversos al riesgo. }\end{array}$ & $\begin{array}{l}\text { Participación directa del Tesoro en el } \\
\text { mercado de deuda pública en escenarios } \\
\text { de volatilidad. } \\
\text { Mayor desarrollo del mercado de bonos } \\
\text { indexados a la inflación para evitar mayor } \\
\text { dolarización de inversionistas adversos al } \\
\text { riesgo. }\end{array}$ \\
\hline \multicolumn{2}{|c|}{ Dolarización financiera } \\
\hline $\begin{array}{l}\text { Mayor confianza en el dólar como reserva } \\
\text { de valor incrementa la dolarización } \\
\text { financiera. } \\
\text { Mayor descalce de balance de las entidades } \\
\text { financieras deteriora sus resultados, } \\
\text { su solvencia patrimonial y costo de } \\
\text { financiamiento. }\end{array}$ & $\begin{array}{l}\text { El uso extensivo de un programa de } \\
\text { subastas ordinarias de títulos del } \\
\text { Tesoro para mantener confianza en los } \\
\text { inversionistas locales. }\end{array}$ \\
\hline
\end{tabular}

Fuente: MEF (2015a). Elaboración: Propia 


\section{N. Escenario apuesta}

Según Balbi (2010, p. 62-66), el escenario apuesta se construye definiendo objetivos estratégicos específicos para cada variable e indicador y que serán alcanzados en el horizonte de tiempo seleccionado, bajo los parámetros de factibilidad, de relaciones costo-beneficio y de interacciones que sean aceptables y posibles. Para definir los objetivos estratégicos específicos debe mirarse primero los resultados cualitativos (calificados de 0 a 10) que se obtendrían en el escenario tendencial. En los casos que los resultados sean satisfactorios, se deberá elaborar un plan que asegure que las tendencias se cumplan. Si el escenario tendencial no es satisfactorio, debe valorarse si es factible alcanzar el escenario óptimo para dicha variable e indicador y, en el hipotético caso que sea factible alcanzarlo en el horizonte de tiempo seleccionado, se elaborará un plan para conseguirlo. Si el escenario óptimo no es factible, se debe establecer la posición relativa de apuesta (entre el tendencial y el óptimo) que se tratará de alcanzar para la variable e indicador involucrado en el futuro analizado y el plan para lograrlo, y a partir de las calificaciones cualitativas de apuesta para cada variable se puede convertirlas en objetivos estratégicos específicos. De este modo, el siguiente paso será determinar qué acciones, con su respectivo resultado o meta, debería realizarse en el campo de cada variable, para llegar desde el escenario actual hasta el escenario apuesta en el horizonte de tiempo involucrado. Para ello deberá verificarse que no haya redundancia ni incoherencia operativa en el plan, es decir, que no haya más de una acción con resultados similares y que ninguna acción pueda dificultar, perturbar o impedir la realización de otra acción, en la misma o en otra variable. Teniendo las acciones depuradas, cada una se califica de 0 a 10 por importancia y por factibilidad (real capacidad de realizar la acción y obtener el resultado esperado). De esta manera, el corazón del plan estará definido por las acciones que hayan obtenido una calificación mayor de 5 en importancia y en factibilidad y se descartan las que tengan una calificación menor de 5 en ambos. Las que tengan una calificación mayor de 5 en importancia y menor de 5 en factibilidad son retos que deben trabajarse, para mejorar su gobernabilidad, y las otras se dejan a discreción, al ser poco importantes, pero viables.

En el ejercicio, como en 2008 el Perú se adhirió al Centro de Desarrollo de la OCDE y en 2014 fue invitado a involucrarse en su Programa País, programa 
centrado en áreas prioritarias para el Perú como crecimiento económico, gobernanza pública, transparencia y lucha contra la corrupción, capital humano y productividad y medio ambiente, brindando un espacio de análisis e intercambio de experiencias sobre las políticas económicas y sociales entre países desarrolladosy en vías de desarrollo, se decidió adoptar por ese escenario como escenario apuesta. De este modo, la construcción del escenario apuesta, o del futuro deseable, toma como base lo analizado en el escenario donde el Perú forma parte de la OCDE a fin de contribuir a alcanzar los estándares con que actualmente cuentan dichos países en materia de gestión de activos y pasivos financieros públicos. Como se aprecia en el Gráfico $\mathrm{N}^{\circ} 7$, el escenario apuesta plantea una situación retadora respecto del escenario actual, recogiendo las mejoras en el largo plazo de los indicadores estratégicos relacionados con los lineamientos de política para la gestión global de activos y pasivos financieros de la Hacienda Pública y que a su vez contribuirán a una mejora de la calificación de riesgo soberano ya que tienen como objetivo los indicadores mostrados por países que además tienen una calificación de riesgo soberano superior a la que cuenta el Perú (escenario óptimo).

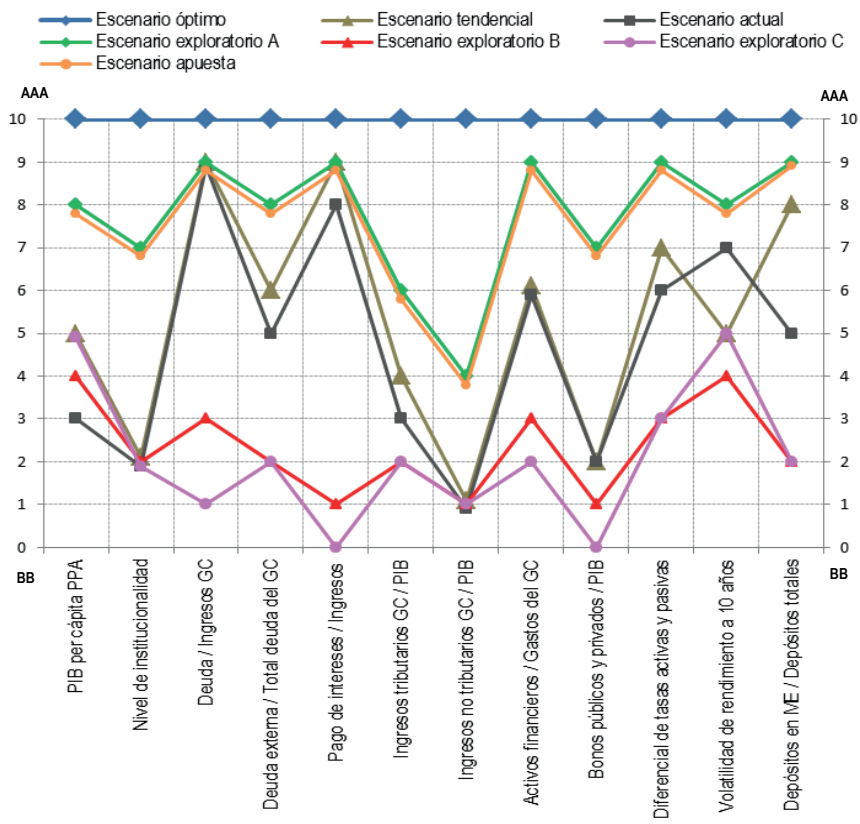

Gráfico 7. Escenario apuesta

Fuente: MEF (2015a). Elaboración: Propia 


\section{Rutas estratégicas y plan}

Según Balbi (2010, p. 70), en este último paso debe analizarse y seleccionarse la secuencia y oportunidad en que se realizarán las acciones identificadas como importantes. El criterio predominante es la combinación secuencial de acciones y resultados, así como la determinación de la cadena de efectos que se produciría. Como hay varias posibilidades, cada curso o modo de actuar generará una ruta estratégica, dividida por tramos constituidos por un conjunto coherente de acciones y resultados que permitan obtener un objetivo intermedio en el camino a alcanzar el escenario apuesta. Así, las diversas rutas estratégicas deben ser comparadas en términos de calidad y respecto de los mapas de riesgos y oportunidades, las raíces o causas de las situaciones críticas y toda la inteligencia estratégica obtenida en los pasos anteriores. Y la ruta estratégica seleccionada será el núcleo central del plan a elaborar. Para no perder posteriormente la capacidad de anticipación generada, una vez puesto en marcha el plan estratégico resultante, se debería construir un sistema de alertas tempranas a partir de la pregunta ¿qué cosas, datos, eventos o sucesos debería observar y medir para obtener una alerta de aumento de la posibilidad de configuración de cada uno de los riesgos identificado en los mapas de riesgos y oportunidades ya elaborados? Estos indicios de pre-configuración permitirán promover inmediatamente cambios en las acciones y planes estratégicos para evitar la configuración de los riesgos involucrados.

En el ejercicio, para poder implementar una gestión global de activos y pasivos en todo el sector público, en 2011ya se habían identificado 16 acciones estratégicas importantes agrupadas en torno a cuatro lineamientos de política (MEF 2011 y 2011a, citados en MEF 2014a: 2426). Además, para poder formular y difundir el primer tramo de un plan estratégico más detallado, antes se había tenido que sustentar, ante el Congreso de la República, modificaciones en la Ley General del Sistema Nacional de Endeudamiento (CRP 2005a) y la Ley General del Sistema Nacional de Tesorería (CRP 2006) con el fin de incluir como objetivo fundamental (intermedio) el desarrollo del mercado de valores de deuda pública y permitir que el tesoro pueda realizar todo tipo de operaciones financieras que contribuyan al desarrollo del mercado de valores, como se hacen en otros países, además de obtener la facultad para que 
apruebe normas específicas que reglamenten las subastas de fondos públicos (MEF 2012) y de letras y bonos soberanos (GP 2013 y 2013a) o se pueda mejorar la calidad y oportunidad de la información para la toma de decisiones (MEF 2013a). De esta manera, primero en forma resumida (MEF 2013) y luego en forma más detallada (MEF 2014a) ya se había empezado a difundir un plan, como una combinación secuencial de acciones y resultados esperados por tramos anuales intermedios, con proyecciones para los siguientes tres años, y cuyos resultados de implementación progresivamente se empezaron a reportar al Congreso (MEF 2014 y 2015). Por ello, la inclusión del análisis prospectivo en la difusión del siguiente tramo de la estrategia (MEF 2015a) en realidad permitió explicitar y ampliar la apuesta de futuro que implícitamente se había seguido y consolidar las bases para revisar posteriormente su alineación en curso (MEF 2016).

\section{Conclusiones}

La utilización de prospectiva estratégica y la generación de inteligencia estratégica dentro de los estados no sólo son posibles sino que son imprescindibles para buscar alcanzar el desarrollo económico, independientemente de que un menor desarrollo esté explicado por la teoría de la modernización o la teoría de la dependencia (Bartch 2017): no habrá desarrollo económico de manera espontánea ni con improvisación sistemática. No sólo las empresas las necesitan como herramienta de anticipación estratégica para explorar y planificar el futuro más viable para sus negocios de lucro, sino que los estados las necesitan para explorar y planificar cómo alcanzar el futuro más viable para sus quehaceres fundamentales: promover un mayor bienestar para sus ciudadanos. Por ejemplo, el desarrollo económico del Perú requiere una estructura productiva diversificada que reduzca la dependencia de la exportación de materias primas, pero para cambiar esto se necesitan instituciones públicas capaces de investigar, formular e implementar políticas y estrategias públicas con visión de futuro (Dancourt y Jiménez 2017).

Los países que han utilizado la prospectiva han logrado desarrollarse con mayor rapidez, pero su aprovechamiento necesita mucha concienciación y voluntad como política de estado, pues, su formulación, desarrollo y resultados trascienden a los ciclos políticos cortoplacistas 
de los diferentes gobernantes de turno. Este trabajo mostró un ejercicio de prospectiva estratégica para mejorar la toma de decisiones dentro del tesoro público peruano y aspirar a alcanzar un escenario apuesta audaz, pese a los grandes peligros que fueron evidenciados en los escenarios exploratorios adversos. El mayor o menor progreso en la implementación de los planes identificados para mitigar los riesgos y aprovechar las oportunidades de cada uno de estos escenarios se reflejará directamente en la mejor o peor calificación de riesgo soberano del Perú. No obstante, en el futuro que empieza está el reto de más largo aliento.

\section{Anexos}

\section{Anexo 1}

Definición de componentes temáticos del árbol de pertinencias

\begin{tabular}{|c|c|}
\hline $\begin{array}{c}\text { Componente o } \\
\text { subcomponente }\end{array}$ & Definición \\
\hline Ingresos públicos & Todas las transacciones que incrementan el patrimonio neto del gobierno \\
general se clasifican como ingreso.
\end{tabular}


Pensamiento Crítico Vol. 22. $\mathrm{N}^{\circ} 2$

\begin{tabular}{|c|c|}
\hline $\begin{array}{l}\text { Componente o } \\
\text { subcomponente }\end{array}$ & Definición \\
\hline $\begin{array}{l}\text { Activos no } \\
\text { financieros }\end{array}$ & $\begin{array}{l}\text { Todos aquellos recursos controlados como consecuencia de hechos pasados } \\
\text { y de los cuales la entidad espera obtener en el futuro beneficios económicos o } \\
\text { potenciales de servicios, pero distinto de los activos financieros. }\end{array}$ \\
\hline $\begin{array}{l}\text { Pasivos } \\
\text { financieros } \\
\text { (deuda pública) }\end{array}$ & $\begin{array}{l}\text { Los pasivos financieros consisten en a) una obligación contractual: (i) de } \\
\text { entregar efectivo u otro activo financiero a otra entidad; o (ii) a intercambiar } \\
\text { activos financieros o pasivos financieros con otra entidad, en condiciones que } \\
\text { sean potencialmente desfavorables para la entidad; o (b) un contrato que será } \\
\text { o podrá ser liquidado utilizando instrumentos de patrimonio propios de la } \\
\text { entidad, y sea: (i) un instrumento no derivado, según el cual la entidad está o } \\
\text { puede estar obligada a entregar una cantidad variable de sus instrumentos } \\
\text { de patrimonio propios; o (ii) un instrumento derivado que será o podrá ser } \\
\text { liquidado mediante una forma distinta al intercambio de un importe fijo de } \\
\text { efectivo, o de otro activo financiero, por una cantidad fija de los instrumentos } \\
\text { de patrimonio propio de la entidad. Por ejemplo, constituyen deuda pública } \\
\text { los títulos, contratos y cualquier otro pasivo financiero reconocido por la } \\
\text { utilización de fondos utilizados para financiar necesidades pasadas. }\end{array}$ \\
\hline $\begin{array}{l}\text { Pasivos no } \\
\text { financieros }\end{array}$ & $\begin{array}{l}\text { Todas aquellas obligaciones presentes que surjan de hechos pasados y } \\
\text { cuya liquidación represente un flujo de salida de recursos, pero diferentes } \\
\text { de un pasivo financiero (por ejemplo, cuentas por pagar a proveedores, } \\
\text { remuneraciones por pagar, contribuciones sociales por pagar, reservas } \\
\text { actuariales por pensiones, obligaciones por construcción de obras públicas, } \\
\text { sentencias judiciales desfavorables firmes, etc.). }\end{array}$ \\
\hline Contingencias & $\begin{array}{c}\text { Todos los posibles activos y pasivos que afecten a las finanzas públicas y sobre } \\
\text { los que existe incertidumbre acerca de su cuantía o vencimiento. No obstante, } \\
\text { deben ser reconocidos como provisiones cuando se cumplen las tres siguientes } \\
\text { condiciones simultáneamente: (i) la entidad tiene una obligación presente } \\
\text { (ya sea legal o implícita) como resultado de un suceso pasado; (ii) es probable } \\
\text { que la entidad tenga que desprenderse de recursos, que incorporen beneficios } \\
\text { económicos para cancelar tal obligación; y (iii) puede hacerse una estimación } \\
\text { fiable del importe de la obligación. }\end{array}$ \\
\hline $\begin{array}{l}\text { Participación } \\
\text { en empresas } \\
\text { públicas }\end{array}$ & $\begin{array}{c}\text { Valor de la porción de derechos de propiedad que el gobierno general, en } \\
\text { cualquiera de sus } 3 \text { niveles, tiene sobre el patrimonio neto de empresas, sea } \\
\text { que estén bajo régimen público o privado, e independientemente de que las } \\
\text { empresas sean o no financieras, hayan emitido o no acciones. }\end{array}$ \\
\hline $\begin{array}{l}\text { Promoción de la } \\
\text { inversión }\end{array}$ & $\begin{array}{l}\text { Acciones dirigidas a mejorar e incrementar los niveles de inversión para la } \\
\text { provisión de infraestructura pública, servicios públicos y demás servicios } \\
\text { relacionados que brinda o requiera brindar el Estado. }\end{array}$ \\
\hline Inversión pública & $\begin{array}{c}\text { Inversión realizada con recursos públicos destinados a crear, incrementar, } \\
\text { mejorar o reponer las existencias de capital físico de dominio público, con } \\
\text { el objeto de ampliar la capacidad del país para la prestación de servicios } \\
\text { y producción de bienes, así como para mejorar la productividad y la } \\
\text { competitividad del país. }\end{array}$ \\
\hline
\end{tabular}




\begin{tabular}{|c|c|}
\hline $\begin{array}{l}\text { Componente o } \\
\text { subcomponente }\end{array}$ & Definición \\
\hline $\begin{array}{l}\text { Inversión } \\
\text { privada }\end{array}$ & $\begin{array}{l}\text { Acciones de política dirigidas al desarrollo y promoción de la inversión privada } \\
\text { en la provisión de infraestructura pública y servicios públicos. }\end{array}$ \\
\hline $\begin{array}{l}\text { Mercado de } \\
\text { bienes y servicios }\end{array}$ & $\begin{array}{l}\text { Acciones sobre los mercados en los que interactúan vendedores y compradores } \\
\text { de bienes y servicios. }\end{array}$ \\
\hline Mercado externo & $\begin{array}{l}\text { Acciones centradas en mejorar y garantizar las condiciones de apertura del país } \\
\text { respecto del mundo, facilitando las operaciones de comercio exterior de los } \\
\text { diferentes agentes involucrados en temas de aduanas (control y fiscalización } \\
\text { de operaciones de comercio exterior y política arancelaria) y de restricciones } \\
\text { al comercio (resguardo de objetivos legítimos como los de seguridad nacional, } \\
\text { prevención de prácticas que induzcan a error, protección de la salud y la vida } \\
\text { humana, animal y vegetal o del medio ambiente, etc.). }\end{array}$ \\
\hline Mercado interno & $\begin{array}{l}\text { Acciones centradas en mantener el equilibrio entre la regulación necesaria para } \\
\text { resolver fallas de mercado y evitar interferir con las interacciones eficientes del } \\
\text { mercado, especialmente para asegurar la concurrencia de la libre competencia } \\
\text { y eliminación de barreras de acceso al mercado como para la mejora sostenible } \\
\text { de la competitividad y productividad, actuando como balance entre los } \\
\text { objetivos sectoriales y los objetivos de desarrollo más amplio. }\end{array}$ \\
\hline $\begin{array}{l}\text { Mercados } \\
\text { financieros }\end{array}$ & $\begin{array}{l}\text { Mecanismos a través de los cuales se interrelacionan agentes deficitarios } \\
\text { y superavitarios de fondos o instrumentos financieros dentro de un marco } \\
\text { institucional constituido por reglas y organismos reguladores y supervisores. }\end{array}$ \\
\hline $\begin{array}{l}\text { Profundización } \\
\text { financiera }\end{array}$ & $\begin{array}{c}\text { Provisión de servicios financieros en el país para todos sus niveles en sus } \\
\text { diferentes alternativas. }\end{array}$ \\
\hline $\begin{array}{l}\text { Costos } \\
\text { financieros }\end{array}$ & $\begin{array}{l}\text { Costos de los diferentes agentes económicos del país para utilizar los servicios } \\
\text { de las entidades financieras. }\end{array}$ \\
\hline $\begin{array}{l}\text { Estabilidad } \\
\text { financiera }\end{array}$ & $\begin{array}{c}\text { Situación en la que las entidades financieras facilitan la asignación eficiente } \\
\text { de fondos y las autoridades aseguran el buen funcionamiento de la cadena de } \\
\text { pagos y gestión de los riesgos sistémicos ante perturbaciones o fenómenos no } \\
\text { anticipados. }\end{array}$ \\
\hline $\begin{array}{l}\text { Actividad } \\
\text { empresarial del } \\
\text { Estado }\end{array}$ & $\begin{array}{c}\text { Actividad efectuada por las empresas públicas de cualquiera de los tres niveles } \\
\text { de gobierno. }\end{array}$ \\
\hline $\begin{array}{l}\text { Gestión } \\
\text { empresarial }\end{array}$ & $\begin{array}{c}\text { Acciones centradas en mejorar la eficiencia, competitividad, responsabilidad } \\
\text { social y buen gobierno corporativo. }\end{array}$ \\
\hline Rol subsidiario & $\begin{array}{c}\text { Acciones para cubrir las necesidades de la población sustentadas en el alto } \\
\text { interés público o manifiesta conveniencia nacional sin que ello implique una } \\
\text { reserva exclusiva a favor del Estado. }\end{array}$ \\
\hline
\end{tabular}


Pensamiento Crítico Vol. 22. $\mathrm{N}^{\circ} 2$

Anexo 2

Relación de variables, indicadores y fuentes

\begin{tabular}{|c|c|c|c|}
\hline $\mathbf{N}^{\circ}$ & Variable & Indicador & Fuente \\
\hline 1 & Producto interno bruto & PIB per cápita $P_{P A}^{6}$ & Moody's Statbook \\
\hline 2 & Institucionalidad & Índice de institucionalidad $\mathrm{WEF}^{7}$ & $\begin{array}{l}\text { World Economic } \\
\text { Forum }\end{array}$ \\
\hline 3 & $\begin{array}{l}\text { Desarrollo de mercados } \\
\text { financieros }\end{array}$ & $\begin{array}{l}\text { Saldo bonos públicos y privados emitidos } \\
\text { en moneda local / PIB } \\
\text { Diferencial de tasas de interés activas y } \\
\text { pasivas }\end{array}$ & SBS, SMV y BCRP \\
\hline 4 & Dolarización financiera & $\begin{array}{l}\text { Total depósitos en moneda extranjera / } \\
\text { Total de depósitos }\end{array}$ & SBS \\
\hline 5 & Estabilidad Financiera & $\begin{array}{l}\text { Desviación estándar de rendimiento a } 10 \\
\text { años del Tesoro Público }\end{array}$ & Bloomberg \\
\hline 6 & Deuda pública & $\begin{array}{l}\text { Deuda / Ingresos GC } \\
\text { Deuda externa /Total deuda del GC } \\
\text { Pago de intereses / Ingresos GC }\end{array}$ & $\begin{array}{l}\text { MEF, BCRP, } \\
\text { Moody's Statbook }\end{array}$ \\
\hline 7 & Activos no financieros & $\begin{array}{l}\text { Total de caminos pavimentados (en } \\
\text { metros) / Km2 de territorio }\end{array}$ & $\begin{array}{l}\text { Banco Mundial, } \\
\text { Ministerio de } \\
\text { Transporte }\end{array}$ \\
\hline 8 & Ahorro público & Activos financieros / Gastos GC & MEF, BCRP \\
\hline 9 & Gasto financiero & Pago de intereses / PBI & MEF, BCRP \\
\hline 10 & Gasto de consumo & Gasto corriente del GC / PIB & BCRP \\
\hline \multirow{2}{*}{11} & \multirow{2}{*}{ Ingreso público } & Ingresos tributarios GC / PIB & BCRP \\
\hline & & Ingresos no tributarios GC / PIB & BCRP \\
\hline 12 & Desempeño económico de China & Crecimiento PIB China & Banco Mundial \\
\hline 13 & Inversión en ciencia y tecnología & Gasto I\&D / PIB & CONCYTEC \\
\hline 14 & Mercado de materias primas & Índice de precios de minerales ${ }^{8}$ & FMI Index \\
\hline 15 & Flujo de capitales & Balanza en cuenta corriente / PIB & BCRP \\
\hline 16 & Política monetaria de los EEUU & Tasa de referencia de la Reserva Federal & Bloomberg \\
\hline
\end{tabular}

${ }^{6}$ Paridad de poder adquisitivo.

${ }^{7}$ El indicador es calculado anualmente por el Foro Económico Mundial (WEF) tomando en cuenta una serie de características cualitativas institucionales por países, tales como independencia de poder judicial, corrupción, infraestructura, entre otros.

${ }^{8}$ IMF Primary Commodity Prices $(2005=100)$. 
Anexo 3

Matriz de categorización por motricidad y dependencia

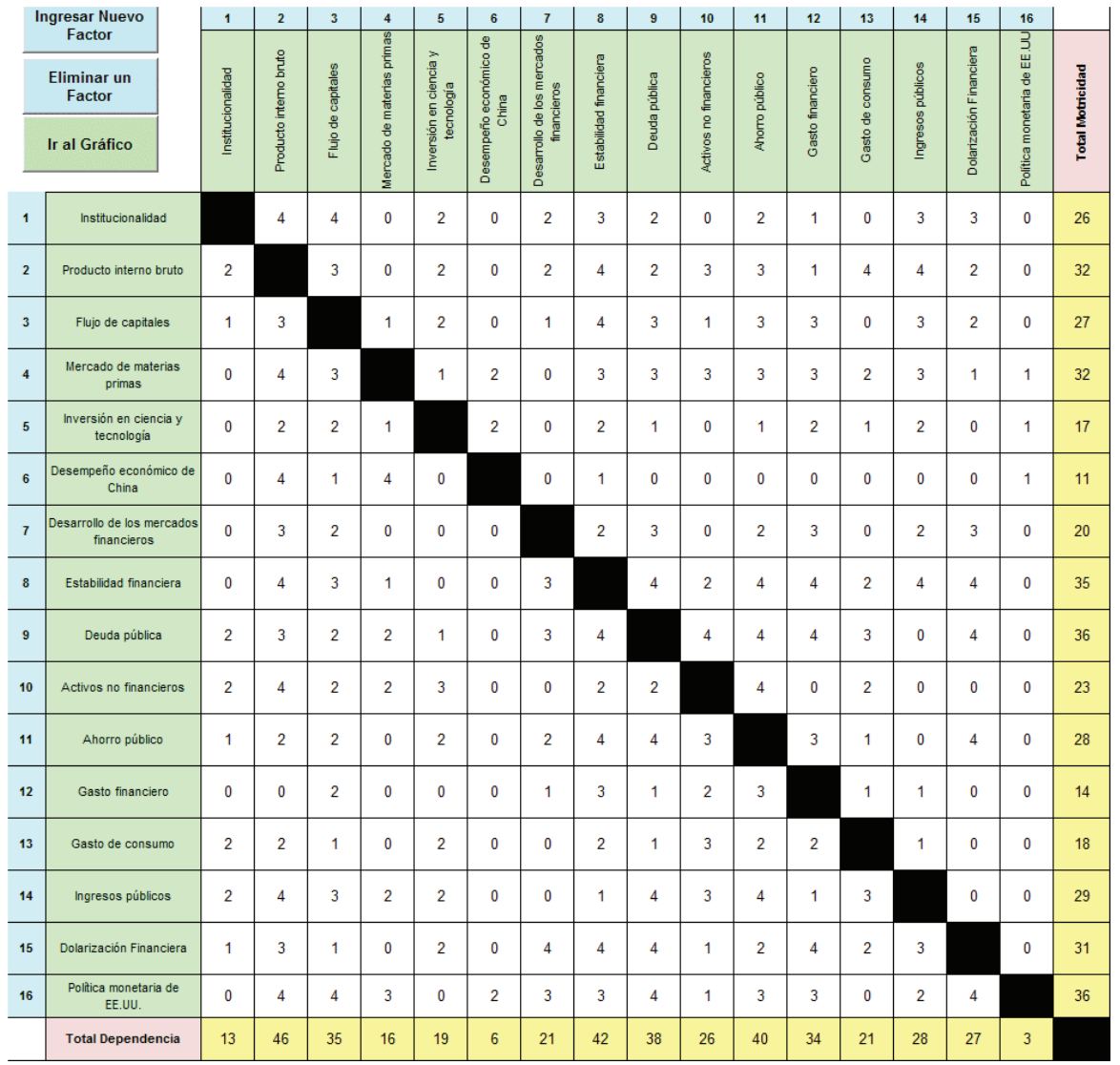


Pensamiento Crítico Vol. 22. N²

\section{Anexo 4 \\ Estimación para indicadores estratégicos en escenario tendencial (Mejor método de ajuste ${ }^{9}$ )}

\begin{tabular}{|c|c|c|}
\hline Variable & Indicador & Año 2030 \\
\hline Producto interno bruto & PIB per cápita (US\$, PPA) & 16606 \\
\hline
\end{tabular}

Eventos para esta serie

Datos históricos:

Estadisticas
Valores de dato

Mínimo

Media

Meximo

Ljung-Box

Ejung-Box

Valores filtrados

Precisión de previsión

Método

Suavizado exponencial doble

ARIMA $(0,2,1)$

Promedio móvil doble

Datos históricos

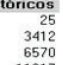

3412
6570
11817

11817
2687

2687 (Sin tendencie)

No estacionol (Detección automático)

1

Método

Suavizado exponencial doble

ARIMA $(0,2,1)$

Promedio móvil doble

Rango RMSE

\begin{tabular}{rr} 
Mejor & RMSE \\
2.2 & 171 \\
3.2 & 222 \\
\hline
\end{tabular}

Parámetros de método

Método
Suavizado exponencial doble

ARIMA(0,2,1)

Promedio móvil doble

U de Theil

$\begin{array}{rr}\text { Theil } & \text { Durbin-Watson } \\ 0.4611 & 1.76 \\ 0.5373 & 1.85\end{array}$

0.5942

1.85
1.74

\begin{tabular}{rr} 
Parámetro & Valor \\
Alfa & 0.9990 \\
Beta & 0.8961 \\
Orden & - \\
\hline
\end{tabular}

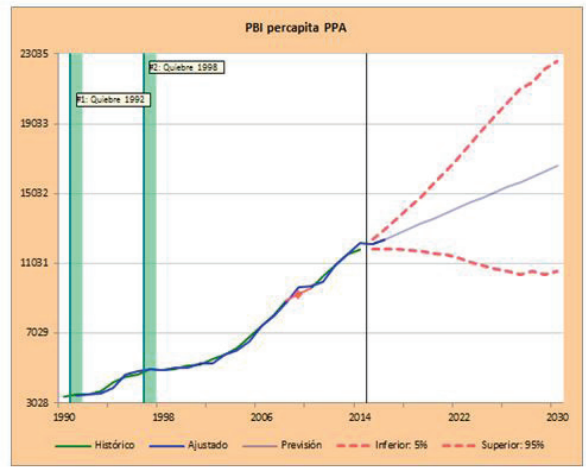

\begin{tabular}{|c|c|c|}
\hline Variable & Indicador & Año 2030 \\
\hline Institucionalidad & Nivel de Institucionalidad & 3,31 \\
\hline
\end{tabular}

Coeficientes de modelo de ARIMA

$\begin{array}{lrr}\text { Variable } & \text { Coeficiente } & \text { Error estánda } \\ \text { AR(1) } & 1.38 & 0.005 \\ \text { AR(2) } & -0.9499 & 0.0665 \\ \text { MA(1) } & -0.3390 & 0.254 \\ \text { Constante } & 1.94 & \end{array}$

Constante

1.94

Precisión de previsión

\section{Método}

ARIMA(2,0,1)

Suavizado exponencial doble

Promedio móvil doble

Método

ARIMA(20.1)

Suavizado exponencial doble

Promedio móvil doble

Rango RMSE

$\begin{array}{rr}\text { Rango } & \text { RMSE } \\ \text { Mejor } & \mathbf{0 . 0 3} \\ 2.2 & 0.06 \\ 3.2 & 0.07\end{array}$

U de Theil Durbin-Watson

$0.4353 \quad 2.19$

$\begin{array}{ll}0.4353 & 2.19 \\ 0.7371 & 1.44\end{array}$

1.09 * 0.6935

*-Advertencia: $U$ de Theil $>1.0$
*-Advertencia: Durbin-Watson < 1.0

Parámetros de método

\begin{tabular}{lrr}
\hline Método & Parámetro & Valor \\
\hline ARIMA(2,0.1) & - & - \\
Suavizado exponencial doble & Alfa & 0.9990 \\
& Beta & 0.9990 \\
Promedio móvil doble & Orden & 2 \\
\hline
\end{tabular}

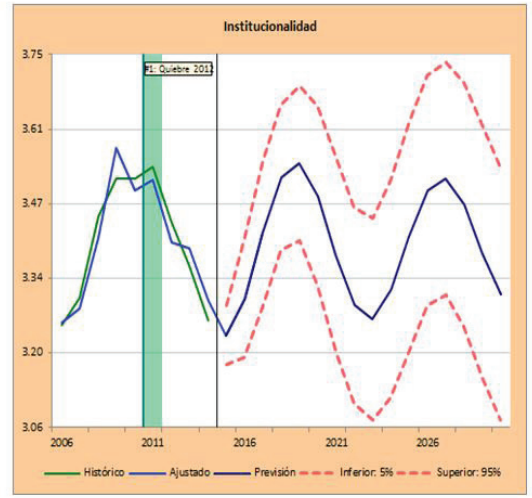

${ }^{9}$ Medido a través de la precisión de la previsión: menor error cuadrático medio y mejor ajuste de la muestra con el método elegido tomando la medida $\mathrm{U}$ de Theil. 
RENZo A. JimÉnez Sotelo

\begin{tabular}{|c|c|c|}
\hline Variable & Indicador & Año 2030 \\
\hline Deuda pública & Deuda GC / Ingresos del GC & 86\% \\
\hline
\end{tabular}

stadísticas de ARIMA

\begin{tabular}{lr} 
ARIMA & Estadisticas \\
Transformación Lambda & 1.00 \\
BIC & -3.65 \\
AIC & -3.77 \\
AlCc & -3.52 \\
\multicolumn{2}{l}{} \\
\end{tabular}

oeficientes de modelo de ARIMA:

$\begin{array}{lrr}\text { Variable } & \text { Coeficiente } & \text { Error estánda } \\ \text { AR(1) } & -0.3233 & 0.249 \\ \text { MA(1) } & -1.57 & 0.1029 \\ \text { MA(2) } & -1.08 & 0.123\end{array}$

recisión de previsión:

Método

ARIMA(1,1,2)

Suavizado exponencial doble

Promedio móvil simple

Método

ARIMA(1.1.2)

Suavizado exponencial doble

Promedio móvil simple

\begin{tabular}{rr} 
& \\
Rango & RMSE \\
Mejor & $\mathbf{1 2 \%}$ \\
2.2 & $18 \%$ \\
3.2 & $24 \%$ \\
& \\
\hline de Theil & Durbin-Watson \\
0.4971 & 1.56 \\
0.9015 & 1.71 \\
1.00 & 0.5304 \\
\hline - Advertencia: Durbin-Watson $<1.0$
\end{tabular}

arámetros de método:

$\begin{array}{lrr}\text { Método } & \text { Parámetro } & \text { Valor } \\ \text { ARIMA(1.1.2) } & - & - \\ \text { Suavizado exponencial doble } & \text { Alfa } & 0.9990 \\ & \text { Beta } & 0.9990 \\ \text { Promedio móvil simple } & \text { Orden } & 1\end{array}$

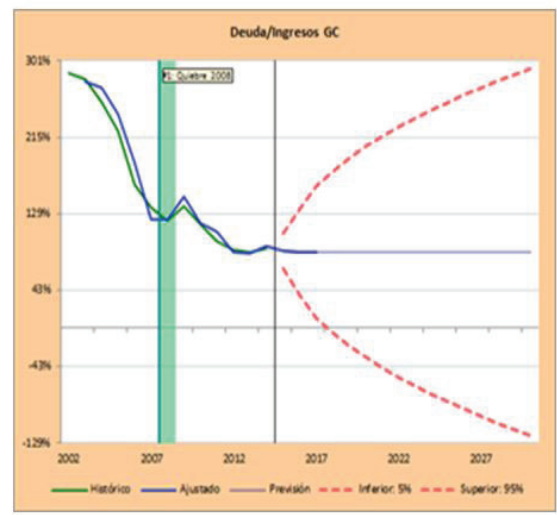

Promedio móvil simple

\begin{tabular}{|c|c|c|}
\hline Variable & Indicador & Año 2030 \\
\hline Deuda pública & $\begin{array}{c}\text { Deuda externa respecto a } \\
\text { deuda total del Gobierno }\end{array}$ & $-3,9 \%$ \\
\hline
\end{tabular}

Datos históricos:

Estadisticas Datos históricos

Valores de datos

Media

Méximo

Desviación estanda

Ljung-Box

Estacionalidad

$\cos$
13
0.50
0.71
0.89

0.89
0.14

7.59 (Sin tendencia)

No estacional

Estadisticas de ARIMA

$\begin{array}{lr}\text { ARIMA } & \text { Estadisticas } \\ \text { Transformación Lambda } & 1.00 \\ \text { BIC } & -7.05 \\ \text { AIC } & -7.09 \\ \text { AICC } & -7.05 \\ & \\ & \text { "Se utiliza para la selección de modelo }\end{array}$

Coeficientes de modelo de ARIMA:

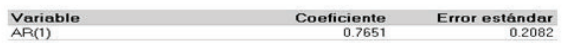

Precisión de previsión:

Método Rango RMSE

ARIMA(1,1,0)

Promedio móvil doble

Suavizado exponencial doble

Mejor

2.0 .01

$\begin{array}{lrr}\text { Método } & U \text { de Theil } & \text { Durbin-Watson } \\ \text { ARIMA }(1,1,0) & 0.6459 & 2.26\end{array}$

Promedio móvil doble

Suavizado exponencial doble

0.6459
0.2711

$\begin{array}{ll}0.2711 & 1.55 \\ 0.5863 & 1.80\end{array}$

Parámetros de método:

Método

ARIMA(1,1,0)

Suavizado exponencial doble

$\begin{array}{rr}\text { Parámetro } & \text { Valor } \\ \text { Orden } & -\frac{4}{4} \\ \text { Alfa } & 0.9990 \\ \text { Beta } & 0.4223\end{array}$

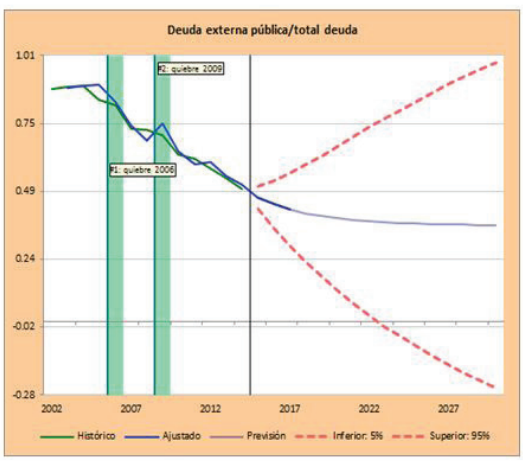


Pensamiento Crítico Vol. 22. N$^{\circ}$

\begin{tabular}{|c|c|c|}
\hline Variable & Indicador & Año 2030 \\
\hline Ingreso público & $\begin{array}{c}\text { Ingresos tributarios respecto } \\
\text { del PIB }\end{array}$ & $17 \%$ \\
\hline
\end{tabular}

Datos históricos:

Estadísticas $\quad$ Datos históricos

$\begin{array}{lr}\text { Estadisticas } & \text { Datos históricos } \\ \text { Valores de datos } & 25 \\ \text { Minimo } & 11.2 \%\end{array}$

Media

Desviación estándar

Ljung-Box

Valores filtrados

$11.2 \%$

$14.2 \%$
$16.6 \%$

No estacional (Detección automática)

Estadisticas de ARIMA

ARIMA Estadísticas

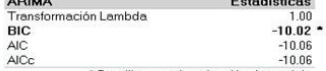

$\begin{array}{lr} & -10.06 \\ \text { AIC } & -10.06 \\ \text { AICC } & \text { Se utiliza pora la selección de madelo }\end{array}$

Coeficientes de modelo de ARIMA.

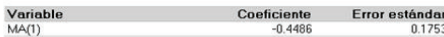

Precisión de previsión

Método

ARIMA(0,1.1)

Suavizado exponencial dob

Promedio móvil simple

APIMA $(0,1,1)$

Suavizado exponencial doble
Promedio móvil simple

Parámetros de método:

\begin{tabular}{lrr} 
Método & Parámetro & Valor \\
\hline ARIMA(0.1.1) & - & - \\
Suavizado exponencial doble & Alfa & 0.9990 \\
Promedio móvil simple & Beta & 0.0327 \\
\hline
\end{tabular}

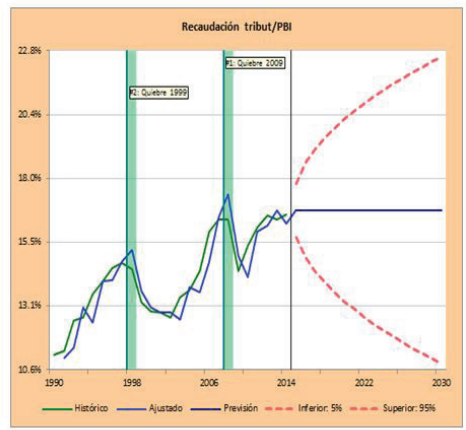

Promedio móvil simple

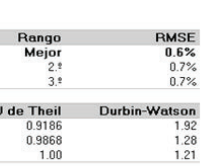

\begin{tabular}{|c|c|c|}
\hline Variable & Indicador & Año 2030 \\
\hline Ingreso público & $\begin{array}{c}\text { Ingresos no tributarios } \\
\text { respecto del PIB }\end{array}$ & $2,9 \%$ \\
\hline
\end{tabular}

Estadisticas

Valores de datos

Minimo

Media

Máximo

Desviación estándar

Ljung-Box

Estacionalidad

Valores filtrados

Datos históricos

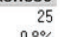

$0.8 \%$

$2.0 \%$

$2.7 \%$

13.82 (Sin tendencia)

No estacional (Detección automática) 0

recisión de previsión:

\begin{tabular}{lrr} 
Método & Rango & RMSE \\
Suavizado exponencial doble & Mejor & $0.2 \%$ \\
Promedio móvil doble & $2 . \%$ & $0.2 \%$ \\
Promedio móvil simple & $3 . ?$ & $0.2 \%$ \\
\hline
\end{tabular}

$\begin{array}{lrr}\text { Método } & \text { U de Theil } & \text { Durbin-Watson } \\ \text { Suavizado exponencial doble } & 0.9795 & 1.81 \\ \text { Promedio móvil doble } & 0.8771 & 1.06 \\ \text { Promedio móvil simple } & 1.00 & 1.72\end{array}$

arámetros de método:

\begin{tabular}{lrr} 
Método & Parámetro & Valor \\
\hline Suavizado exponencial doble & Alta & 0.9990 \\
& Beta & 0.0301 \\
Promedio móvil doble & Orden & 8 \\
Promedio móvil simple & Orden & 1 \\
\hline
\end{tabular}

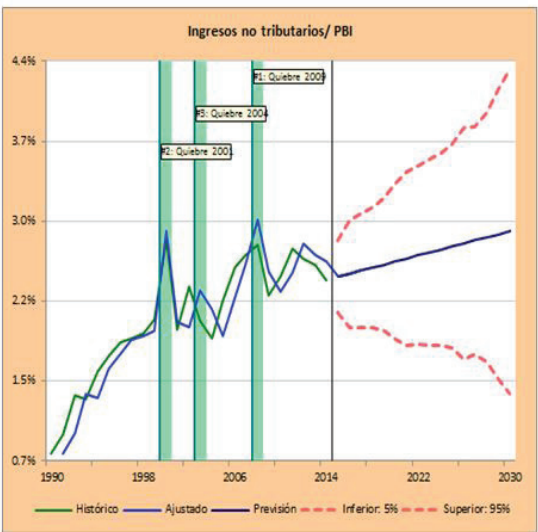


Renzo A. Jiménez Sotelo

\begin{tabular}{|c|c|c|}
\hline Variable & Indicador & Año 2030 \\
\hline Ahorro público & $\begin{array}{c}\text { Activos financieros / Gastos } \\
\text { del GC }\end{array}$ & $58,2 \%$ \\
\hline
\end{tabular}

\begin{tabular}{|c|c|}
\hline ARIMA & Estadisticas \\
\hline Transformación Lambda & 1.00 \\
\hline BIC & -7.51 \\
\hline AIC & -7.53 \\
\hline $\mathrm{AlCC}$ & -7.47 \\
\hline
\end{tabular}

oeficientes de modelo de ARIMA:

$\begin{array}{lrr}\text { Variable } & \text { Coeficiente } & \text { Error estándar } \\ \text { AR(1) } & 0.8300 & 0.0779 \\ \text { recisión de previsión: } & & \\ & & \\ \text { Método } & \text { Rango } & \text { RMSE } \\ \text { ARIMA(1,1.0) } & \text { Mejor } & 2 \% \\ \text { Promedio móvil doble } & 2.2 & 2 \% \\ \text { Suavizado exponencial doble } & 3.2 & 3 \% \\ \text { Método } & & \\ \text { ARIMA(1,1.0) } & \mathrm{U} \text { de Theil } & \text { Durbin-Watson } \\ \text { Promedio móvil doble } & 0.3296 & 1.90 \\ \text { Suavizado exponencial doble } & 0.4316 & 1.15 \\ & 0.7748 & 1.06 \\ \end{array}$

arámetros de método:

\begin{tabular}{lrr} 
Método & Parámetro & Valor \\
\hline ARIMA(1,1,0) & - & - \\
Promedio móvil doble & Orden & 2 \\
Suavizado exponencial doble & Alfa & 0.9990 \\
& Beta & 0.5680 \\
\hline
\end{tabular}

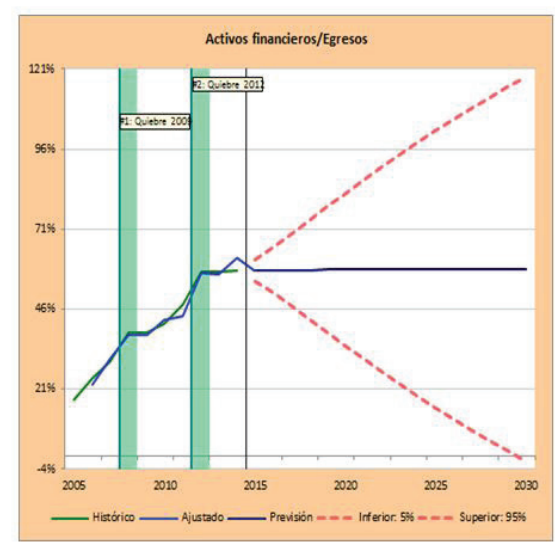

\begin{tabular}{|c|c|c|}
\hline Variable & Indicador & Año 2030 \\
\hline $\begin{array}{c}\text { Desarrollo de mercados } \\
\text { financieros }\end{array}$ & $\begin{array}{c}\text { Bonos privados y públicos en } \\
\text { soles /PIB \% }\end{array}$ & $11,1 \%$ \\
\hline
\end{tabular}

stadísticas de ARIMA:

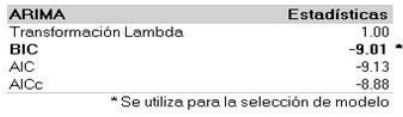

oeficientes de modelo de ARIMA

$\begin{array}{lrr}\text { Variable } & \text { Coeficiente } & \text { Error estánd } \\ \text { AR(1) } & 0.4457 & 0.27 \\ \text { MA(1) } & 0.4734 & 0.11 \\ \text { MA(2) } & -0.9820 & 0.12\end{array}$

recisión de previsión:

\begin{tabular}{|c|c|c|}
\hline Método & Rango & RMSE \\
\hline ARIMA(1,1,2) & Mejor & $1 \%$ \\
\hline Promedio móvil doble & 2.2 & $1 \%$ \\
\hline Suavizado exponencial doble & 3.: & $1 \%$ \\
\hline Método & U de Theil & Durbin-Watson \\
\hline ARIMA(1,1,2) & 0.7194 & 2.10 \\
\hline Promedio móvil doble & 0.7791 & 1.81 \\
\hline Suavizado exponencial doble & 0.8575 & 2.36 \\
\hline \multicolumn{3}{|l|}{ arámetros de método: } \\
\hline Método & Parámetro & Valor \\
\hline ARIMA(1,1,2) & - & - \\
\hline Promedio móvil doble & Orden & 2 \\
\hline \multirow[t]{2}{*}{ Suavizado exponencial doble } & Alfa & 0.6473 \\
\hline & Beta & 0.9990 \\
\hline
\end{tabular}

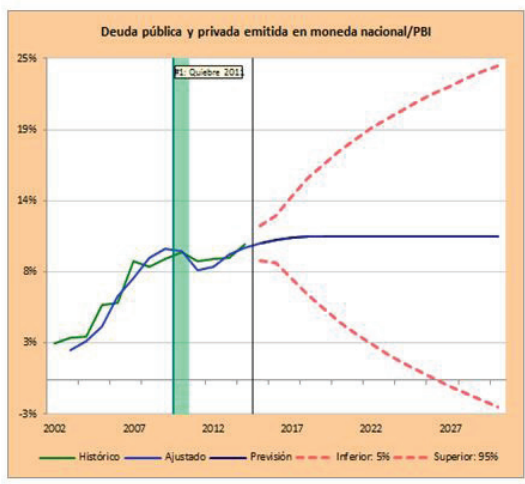


Pensamiento Crítico Vol. 22. N$^{\circ}$

\begin{tabular}{|c|c|c|}
\hline Variable & Indicador & Año 2030 \\
\hline $\begin{array}{c}\text { Desarrollo de mercados } \\
\text { financieros }\end{array}$ & $\begin{array}{c}\text { Diferencial de tasas activasy } \\
\text { pasivas }\end{array}$ & $9,4 \%$ \\
\hline
\end{tabular}

Precisión de previsión:

\begin{tabular}{lrr}
\hline Método & Rango & RMSE \\
Suavizado exponencial doble & Mejor & 1.4 \\
Promedio móvil simple & $2 !$ & 1.4 \\
ARIMA(0,1,0) & $3 ! !$ & 1.4 \\
\hline
\end{tabular}

\begin{tabular}{lrr}
\hline Método & U de Theil & Durbin-Watson \\
Suavizado exponencial doble & 0.9915 & 1.54 \\
Promedio móvil simple & 1.00 & 1.44 \\
ARIMA(0,1,0) & 1.00 & 1.44 \\
\hline
\end{tabular}

Parámetros de método:

\begin{tabular}{lrr}
\hline Método & Parámetro & Valor \\
Suavizado exponencial doble & Alfá & 0.9990 \\
& Beta & 0.0459 \\
Promedio móvil simple & Orden & 1 \\
ARIMA(0,1,0) & - & -
\end{tabular}

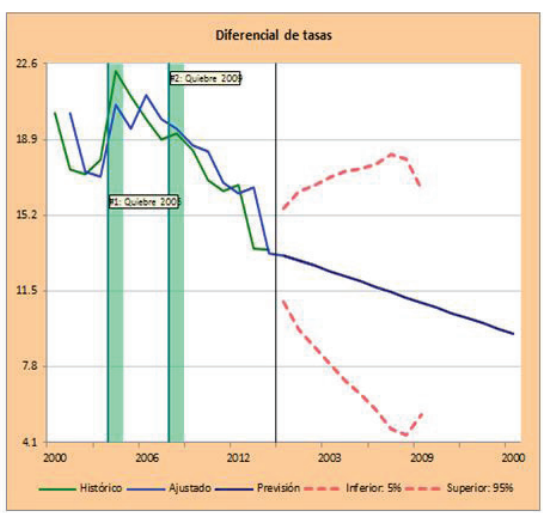

\begin{tabular}{|c|c|c|}
\hline Variable & Indicador & Año 2030 \\
\hline Estabilidad financiera & $\begin{array}{c}\text { Volatilidad de rendimiento del } \\
\text { Tesoro a 10 años }\end{array}$ & $55 \mathrm{pb}$ \\
\hline
\end{tabular}

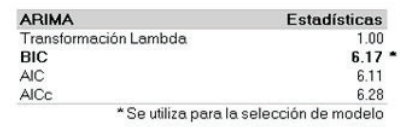

Coeficientes de modelo de ARIMA:

$\begin{array}{lrr}\text { Variable } & \text { Coeficiente } & \text { Error estándar } \\ \text { MA(1) } & 0.9040 & 0.1002 \\ \text { Constante } & 55.21 & \end{array}$

Precisión de previsión:

\begin{tabular}{lrr} 
Método & $\begin{array}{r}\text { Rango } \\
\text { Mejor }\end{array}$ & RMSE \\
\hline ARIMA(0.0.1) & 2.2 & $\mathbf{1 7 . 4}$ \\
Promedio móvil simple & 3.2 & 20.1 \\
Suavizado exponencial doble & & 25.5 \\
\hline Método & U de Theil & Durbin-Watson \\
ARIMA(0,0,1) & 0.4050 & 1.70 \\
Promedio móvil simple & 0.6788 & 1.97 \\
Suavizado exponencial doble & 0.5770 & 2.12 \\
\hline Parámetros de método: & & \\
Método & & \\
ARIMA(0,0,1) & Parámetro & Valor \\
Promedio móvil simple & - & - \\
Suavizado exponencial doble & Orden & 4 \\
& Alfa & 0.0532 \\
\hline
\end{tabular}

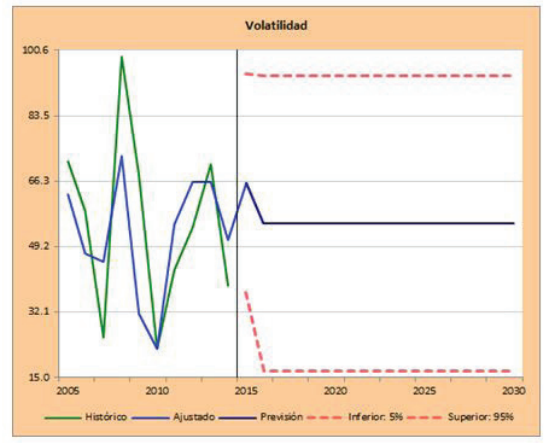




\begin{tabular}{|c|c|c|}
\hline Variable & Indicador & Año 2030 \\
\hline Dolarización financiera & $\begin{array}{c}\text { \% Depósitos bancarios en } \\
\text { moneda extranjera }\end{array}$ & $23,6 \%$ \\
\hline
\end{tabular}

\begin{tabular}{|c|c|c|}
\hline \multicolumn{3}{|l|}{ Precisión de previsión: } \\
\hline Método & Rango & RMSE \\
\hline Suavizado exponencial doble & Mejor & 0.03 \\
\hline ARIMA $(1,1,0)$ & $2:$ & 0.03 \\
\hline Promedio móvil doble & 3.: & 0.03 \\
\hline Método & U de Theil & Durbin-Watson \\
\hline Suavizado exponencial doble & 0.9133 & 1.66 \\
\hline ARIMA $(1,1,0)$ & 0.9357 & 2.11 \\
\hline \multirow[t]{2}{*}{ Promedio móvil doble } & 1.14 * & 1.15 \\
\hline & \multicolumn{2}{|c|}{ *-Advertencia: $U$ de Theil >1.0 } \\
\hline \multicolumn{3}{|l|}{ Parámetros de método: } \\
\hline Método & Parámetro & Valor \\
\hline \multirow{2}{*}{ Suavizado exponencial doble } & Alfa & 0.9990 \\
\hline & Beta & 0.1168 \\
\hline ARIMA $(1,1,0)$ & - & - \\
\hline Promedio móvil doble & Orden & 3 \\
\hline
\end{tabular}

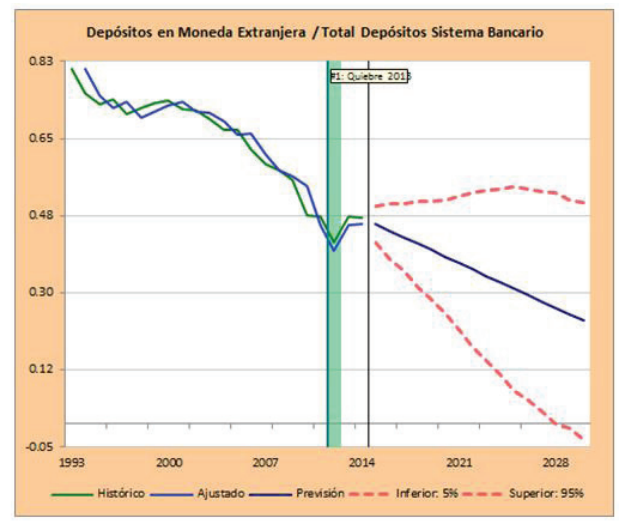

\section{Referencias}

Ackoff, Russel L. (1973). Méthodes de planification dans l'entreprise [Métodos de planificación dentro de la empresa]. París: Les Editions d'organisation.

Balbi, Eduardo. (2010). "Metodología prospectiva. Método MEYEP de prospectiva estratégica. Manual Básico del Método Oficial de Prospectiva de la Red EyE (Escenarios y Estrategia) en América Latina". Serie Futuro 32. Buenos aires: Red de Escenarios \& Estrategia en América Latina. 77 p. 3ra edición. Recuperado de http://190.104.117.163/2014/agosto/enfoque/contenido/ ponencias/futuro32.pdf

Balbi, Eduardo. (2014). “Construyendo el futuro: Metodología prospectiva. Método MEYEP de prospectiva estratégica". Serie Futuro 41. Buenos aires: Red de Escenarios \& Estrategia en América Latina. 162 p. 4ta edición. Recuperado de http://archivo.cepal.org/pdfs/GuiaProspectiva/Balbi2014_ NvoMEYEP_COMPLETO_final.pdf

Balbi, Eduardo. (2015). "Perú nos ilumina el camino. Prospectiva aplicada integralmente al sector público". En G. Baena Paz [coordinadora]. Planeación estratégica prospectiva: Teorías, metodologías y buenas prácticas en América Latina. México DF: Universidad Nacional Autónoma de México. Recuperado de https://www2.politicas.unam.mx/publicaciones/wp-content/ uploads/2015/08/Libro-PPE_interactivo1.pdf 
Bartch, Catherin. (2017, 14 de junio). Posgrado UP y Escuela de Negocios Wharton - Desarrollo Económico en Latinoamérica. Entrevista brindadas a raíz de la conferencia "Economic development in Latin America: an overview of competing perspectives". Lima: Escuela de Posgrado de la Universidad del Pacífico. Recuperado de https://www.youtube.com/ watch?v=d8LGdycGRtg\&sns=em

Congreso de la República del Perú [CRP]. (2005, 6 de mayo). Ley № 28522. Ley del Sistema Nacional de Planeamiento Estratégico y del CEPLÁN.

Congreso de la República del Perú [CRP]. (2005a, 30 de junio). Ley № 28693. Ley General del Sistema Nacional de Endeudamiento y modificatorias.

Congreso de la República del Perú [CRP]. (2006, 20 de marzo). Ley № 28693. Ley General del Sistema Nacional de Tesorería y modificatorias.

Centro Nacional de Planeamiento Estratégico [CEPLÁN]. (2014, 4 de abril). Resolución № 026-2014-CEPLÁN/PCD. Directiva № 001-2014-CEPLÁN Directiva General del Proceso de Planeamiento Estratégico - Sistema Nacional de Planeamiento Estratégico.

Centro Nacional de Planeamiento Estratégico [CEPLÁN]. (2015). "Perú 2021: País OCDE”. Serie Avance de Investigación, número 1. Lima: autor. Recuperado de http://www.rree.gob.pe/Documents/2017/OCDE_2021.pdf

Centro Nacional de Planeamiento Estratégico [CEPLÁN]. (2014a, 19 de junio). Construyendo el Perú que todos queremos. Ponencia presentada durante el taller de capacitación en el Ministerio de Economía y Finanzas. Lima: autor.

Comisión Económica para América Latina y el Caribe [CEPAL]. (2015). "Panorama Fiscal de América Latina y el Caribe 2015: Dilemas y espacios de políticas". Serie Panorama Fiscal de América Latina y el Caribe. Recuperado de http:// repositorio.cepal.org/handle/11362/37747

Dancourt Masías, Óscar y Jiménez Sotelo, Renzo. (2017). La experiencia de la banca de desarrollo en el Perú: 1990-2015. Manuscrito en preparación, Pontificia Universidad Católica del Perú (PUCP) y Universidad del Pacífico (UP), Lima, Perú.

Fondo Monetario Internacional [FMI]. (2015, abril). "Crecimiento dispar: factores a corto y largo plazo". Informe Perspectivas de la Economía Mundial. Washington: autor.

Fondo Monetario Internacional [FMI]. (2015a, 4 de junio). “Consulta del Artículo IV de 2015 con Estados Unidos de América: Declaración al final de la misión 
del FMI". Washington: autor. Recuperado de https://www.imf.org/es/News/ Articles/2015/09/28/04/52/mcs060415

Godet, Michael y Durance, Philippe. (2007). "Prospectiva estratégica: problemas y métodos". Cuaderno 20. París y San Sebastián: Laboratoire d'Investigation Prospective et Stratégique y Prospektiker - Instituto Europeo de Prospectiva y Estrategia. 2da edición. 105 p. Recuperado de http://www.laprospective. $\mathrm{fr} / \mathrm{dyn} /$ francais/memoire/Cajadeherramientas2007.pdf

Gobierno del Perú [GP]. (1962, 19 de octubre). Decreto Ley № 14220. Ley que crea el sistema nacional de planificación del desarrollo económico y social del país.

Gobierno del Perú [GP]. (1981, 12 de junio). Decreto Legislativo № 177. Ley Orgánica del Sistema Nacional de Planificación.

Gobierno del Perú [GP].(1992, 14 de junio) Decreto Ley № 25548. Crean la Comisión de Disolución y Transferencia del Instituto Nacional de Planificación - INP.

Gobierno del Perú [GP]. (2008, 27 de junio). Decreto Legislativo № 1088. Ley del Sistema Nacional de Planeamiento Estratégico y del CEPLÁN.

Gobierno del Perú [GP]. (2013, 14 de marzo). Decreto Supremo № 051-2013-EF. Reglamento de letras del tesoro.

Gobierno del Perú [GP]. (2013a, 21 de mayo). Decreto Supremo № 096-2013-EF. Reglamento del programa de creadores de mercados y bonos soberanos.

Hoffman,DavidR.yPolk,Andrew.(2014).ThelongsoftfallinChinesegrowth:business realities, risks and opportunities. Pekín: The Conference-Board. Recuperado de https://www.conference-board.org/retrievefile.cfm?filename=KBIFY15---China-Slowdown---Final-Draftv2.pdf\&type=subsite

Jiménez Sotelo, Renzo. (2010). “Ciclo crediticio y acelerador cambiario: evidencia empírica y consecuencias para la regulación prudencial”. Economía (PUCP). Lima, volumen XXXIII, número 65, enero-junio, pp. 133-176. Recuperado de http://revistas.pucp.edu.pe/index.php/economia/article/view/587

Medina, Javier y Oregón, Édgar. (2006). "Manual de prospectiva y decisiones estratégicas: bases teóricas e instrumentos para América Latina y el Caribe". CEPAL Serie Manuales 51. Santiago: Naciones Unidas. Recuperado de http:// www.cepal.org/es/publicaciones/5490-manual-prospectiva-decisionestrategica-bases-teoricas-instrumentos-america

Miklos, Tomás y Tello, María Elena. (2007). Planeación prospectiva: Una estrategia para el diseño del futuro. México DF: Editorial LIMUSA y Centro de Estudios Prospectivos Fundación Javier Barros Sierra. 204 p. 
Ministerio de Economía y Finanzas [MEF]. (2011, 22 de noviembre). Resolución Ministerial № 807-2011-EF/41. Plan Estratégico Sectorial Multianual 20122016.

Ministerio de Economía y Finanzas [MEF]. (2011a, 12 de diciembre). Resolución Ministerial № 880-2011-EF/41. Plan Estratégico Institucional 2012-2016.

Ministerio de Economía y Finanzas [MEF]. (2012, 28 de febrero). Resolución Directoral № 016-2012-EF/52.03. Lineamientos para la gestión global de activos y pasivos y reglamento de depósitos.

Ministerio de Economía y Finanzas [MEF]. (2013, 24 de mayo). Estrategia de Gestión Global de Activos y Pasivos 2013-2016. Lima: autor. Recuperado de https://www.mef.gob.pe/contenidos/tesoro_pub/gestion_act_pas/ Estrategia_2013_2016.pdf

Ministerio de Economía y Finanzas [MEF]. (2013a, 13 de setiembre). Resolución Directoral No 011-2013-EF/51.01. Oficialización de las Normas Internaciones de Contabilidad del Sector Público.

Ministerio de Economía y Finanzas [MEF]. (2014, 30 de mayo). Informe Anual de la Deuda Pública 2013. Lima: autor. Recuperado de https://www.mef.gob. pe/contenidos/deuda_publ/documentos/Informe_Deuda_Publica_2013.pdf

Ministerio de Economía y Finanzas [MEF]. (2014a, 31 de julio). Estrategia de Gestión Global de Activos y Pasivos 2014-2017. Lima: autor. Recuperado de https://www.mef.gob.pe/contenidos/tesoro_pub/gestion_act_pas/ Estrategia_Gestion_Activos_2014_2017.pdf

Ministerio de Economía y Finanzas [MEF]. (2015, 30 de mayo). Informe Anual de la Deuda Pública 2014. Lima: autor. Recuperado de https://www.mef.gob. pe/contenidos/deuda_publ/documentos/Informe_Deuda_Publica_2014.pdf

Ministerio de Economía y Finanzas [MEF]. (2015a, 30 de diciembre). Estrategia de Gestión Global de Activos y Pasivos 2015-2018. Lima: autor. Recuperado de https://www.mef.gob.pe/contenidos/tesoro_pub/gestion_act_pas/ Estrategia_Gestion_Activos_2015_2018.pdf

Ministerio de Economía y Finanzas [MEF]. (2016, 30 de mayo). Informe Anual de la Deuda Pública 2015. Lima: autor. Recuperado de https://www.mef.gob. pe/contenidos/deuda_publ/documentos/Informe_Deuda_Publica_2015.pdf

Nardelli, Daniel. (2006). "Introducción a la metodología de investigación prospectiva". Compendio de Prospectiva: método de investigación del fenómeno de paz y no violencia. Buenos Aires: Centro de Investigación para la 
Paz. Recuperado de http://www.centropaz.com.ar/publicaciones/futuro/ futuro35.pdf

Quiroz, Alfonso W. (2013). "Historia de la corrupción en el Perú". Serie Perú Problema, 38. Lima: Instituto de Estudios Peruanos e Instituto de Defensa Legal. 